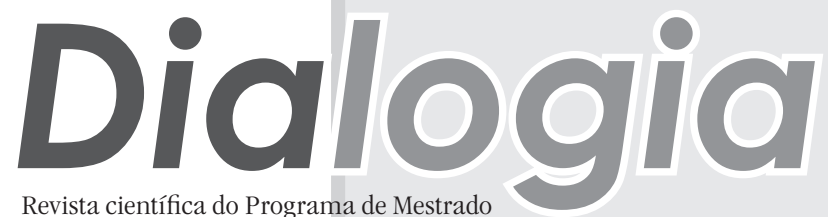

Revista científica do Programa de Mestrado

em Gestão e Práticas Educacionais - PROGEPE

ISSN impresso: 1677-1303

ISSN eletrônico: 1983-9294

\begin{tabular}{|l|l|l|l|l|l|} 
Dialogia & São Paulo & n. 28 & jan./abr. & p. 1-174 & 2018 \\
\hline
\end{tabular}

UNINOVE ○००० 


\section{Dialogia}

dialogia@uninove.br

www.uninove.br/revistadialogia

Endereço para correspondência

Universidade Nove de Julho (UNINOVE)

Rua Vergueiro $n^{\circ} 235 / 249,12^{\circ}$ andar - Liberdade,

São Paulo, SP, Brasil, CEP 01504-001.

Telefone: +55 (11) 3385-9191

\section{Afiliada}

Abec - Associação Brasileira de Editores Científicos www.abecbrasil.org.br

\section{Membro}

Clacso - Conselho Latino-americano de Ciências Sociais. http://www.clacso.org

Fepae - Fórum dos Editores de Periódicos da Área da Educação, da Associação Nacional de Pós-graduação e Pesquisa em Educação - Anped

Bases indexadoras

BBE - Bibliografia Brasileira de Educação - MEC/INEP.

http://pergamum.inep.gov.br/pergamum/biblioteca/ index.php?resolution2 $=1024 \_1$

Clarivate Analytics - http://mjl.clarivate.com/cgi-bin/ jrnlst/jlresults.cgi?PC=MASTER\&Word=Dialogia

CREDI - Centro de Recursos Digitais da Organização dos Estados Ibero-Americanos (OEI).

http://www.oei.es/historico/br146.htm

DOAJ - Directory of Open Access Journals.

https://doaj.org/toc/1983-9294

EBSCO - Academic Databases for Colleges and Universities. https://www.ebscohost.com/titleLists/ aph-journals.htm

ERIH PLUS - Índice Europeu de Referência para as Humanidades (ERIH PLUS). https://dbh.nsd.uib.no/ publiseringskanaler/erihplus/periodical/info?id=485776

IRESIE - Base de datos sobre Educación - IISUE, UNAM

Latindex - Sistema Regional de Información em Línea para Revistas Científicas de América Latina, el Caribe, España y Portugal. http://www.latindex.unam.mx/ latindex/ficha?folio $=17561$

OAJI - http://oaji.net/journal-detail.

html?number $=4613$

REDIB - Red Iberoamericana de Innovación y Conocimiento Científico. https://redib.org/recursos/ Record/oai_revista1099-dialogia

ROAD - Directory of Open Access Scholarly Resources http://road.issn.org/en

\section{Universidade Nove de Julho}

Reitoria: Eduardo Storópoli

Pró-Reitoria Acadêmica: Maria Cristina B. Storópoli

Pró-Reitoria Administrativa: Jean Anastase Tzortzis

Pró-Reitorias de campus: Claudio Ramacciotti

Diretoria de Pesquisa: João Carlos Ferrari Corrêa

Diretoria do Programa de Mestrado em Gestão e Práticas

Educacionais (PROGEPE): Jason Ferreira Mafra

\section{UNINOVE \\ Universidade Nove de}

www.uninove.br
Dialogia é uma publicação científica quadrimestral do Programa de Mestrado em Gestão e Práticas Educacionais (PROGEPE) que se propõe a debater e divulgar os temas relativos às práticas educacionais e ao pensamento pedagógico, especialmente os que resultam das pesquisas realizadas no âmbito dos programas de pós-graduação stricto sensu, nacionais e estrangeiros. Os seus destinatários são, prioritariamente, professores, pesquisadores, estudantes e todo o público que, direta ou indiretamente, mantêm interesse nas questões educacionais.

\section{Dialogia is a quarterly scientific publication} of the Master's Degree Program in Management and Educational Practices (PROGEPE) that proposes to discuss and to become known the themes concerning educational practices and pedagogical thinking specially those that result from researches carried out within the postgraduation nationals and foreign stricto sensu programs. Their receivers are primarily teachers, researchers, students and all kind of public that, directly or indirectly, keeps interest in educational issues.
A instituição ou qualquer dos organismos editoriais desta publicação não se responsabiliza pelas opiniões, ideias e conceitos emitidos nos textos, os quais são de inteira responsabilidade de seu(s) autor(es). 


\section{Comissão Editorial}

Ana Maria Haddad Baptista (editora)

Márcia Fusaro (editora)

Jason Ferreira Mafra

Rosemary Roggero

\section{Conselho Editorial}

Adriana Salete Loss - Universidade Federal da Fronteira Sul [Brasil]

Afonso Celso Scocuglia - Universidade Federal da Paraíba [Brasil]

Ana Luisa Janeira - Universidade de Lisboa [Portugal]

António Teodoro - Universidade Lusófona de Humanidades e Tecnologias [Portugal]

Carlos Bauer - Universidade Nove de Julho [Brasil]

Carlos Rodrigues Brandão - Universidade Estadual de Campinas [Brasil]

Celso de Rui Beisiegel - Universidade de Săo Paulo [Brasil]

Cleiton de Oliveira - Universidade Metodista de Piracicaba [Brasil]

Daniel Carceglia - Universidad Nacional de Quilmes [Argentina]

Edgar Pereira Coelho - Universidade Federal de Viçosa [Brasil]

Genoino Bordignon - Universidade de Brasília [Brasil]

Guillermo Williamson - Universidade La Frontera [Chile]

Joâo Cardoso Palma - Universidade Estadual Paulista [Brasil]

José Amilcar de Carvalho Coelho - Universidade Nova de Lisboa [Portugal]

Luciana P. Marques - Universidade Federal de Juiz de Fora [Brasil]

Luiza Cortesão - Universidade do Porto [Portugal]

Maria Manuela Duarte Guilherme - Universidade de Coimbra [Portugal

Marcella Milana - Universidade de Copenhague [Dinamarca]

Maria Stela Santos Graciani - Pontifícia Universidade Católica-SP [Brasil]

Miguel Escobar Guerrero - Universidad Nacional Autónoma de México [México]

Nilce da Silva - Universidade de São Paulo [Brasil]

Patrícia J. Grandino - Universidade de São Paulo-Leste [Brasil]

Peter Lownds - Paulo Freire Institute [EUA]

Ramon Moncada - Corporación Región [Colômbia]

Ubiratan D’Ambrósio - Universidade de São Paulo [Brasil]

Walter E. Garcia - Instituto Paulo Freire [Brasil]

\section{Equipe editorial}

Juliana Cezario

João Ricardo M. Oliveira 


\section{Sumário / Contents}

\section{Editorial / Editor's note}

Da Educação, das Artes e do pensamento 9 Ana Maria Haddad Baptista

Márcia Fusaro

\section{Entrevista/ Interview}

Educação, Intuição e Temporalidade. .15

Entrevista com o professor Juliano Casimiro de Camargo Sampaio

\section{Dossiê Temático: Educação e Artes /}

\section{Thematic dossier: Education and Arts}

A estética do conhecimento nas redes digitais

The aesthetics of knowledge in digital networks

Clayton Policarpo

Lucia Santaella

A arte (música) e a educação: encontro eterno, esquecimento perene

Art (Music) and Education: everlasting meeting, perennial oblivion

Catarina Justus Fischer

Folhetos de cordel no ensino de língua materna: a aula de leitura revisitada

Cordel leaves in maternal language teaching: the revisited reading class

Linduarte Pereira Rodrigues

Rodrigo Nunes da Silva

Limites e possibilidades do direito à educação pública: contribuições freireanas ao

Ensino Musical

Limits and possibilities of the right to public education:

freirean contributions to the Musical Teaching

Celso do Prado Ferraz de Carvalho

Mauricio Braz de Carvalho

\section{Artigos / Articles}

Uma análise textual dos discursos empregados no gênero redação do enem

A textual analysis about the used discourses in the textual genre wording of enem

Marilúcia dos Santos Domingos Striquer

Língua inglesa como terceira língua: considerações sobre o ensino de línguas

estrangeiras para estudantes surdos na educação básica brasileira.

English as a third language: considerations on foreign language

teaching for deaf students in the Brazilian basic education

Felipe Flores Kupske 
Contribuições do processo reflexivo para o entendimento da prática docente 121

Contributions from the reflexive process for the understanding of the teaching practice

Eliana Alves Arxer

Dulcimeire Ap. Volante Zanon

José Luís Bizelli

Portfólios reflexivos e o ensino de ciências: estratégia inovadora de ensino

133

Reflexive portfolios and science education: innovative teaching strategy

Alessandra Mocellim Gerevini

Diógenes Gewehr

Andreia Aparecida Guimarães Strohschoen

Outras relações entre arte e educação: uma atitude política

Other relations between art and education: a political attitude

Carmen Lúcia Capra

Daniel Bruno Momoli

\section{Resenhas / Reviews}

Lo femenino, entre centro y ausencia,

de Miquel Bassols

Adriano Messias

O culpado,

de Georges Bataille

Mônica de Ávila Todaro

\section{Instruções para os autores / Instructions for authors}

Orientações para submissão de trabalhos à revista Dialogia 


\section{EDITORIAL / EDITOR'S NOTE}




\section{Da Educação, das Artes e do pensamento}

A edição da Revista Dialogia no. 28, Educação e Artes, apresenta um recorte que se pretende atualizado para mostrar, uma vez mais, a importância das Artes para a Educação em todos os níveis e graus. Não se trata, de forma alguma, de encarar as Artes, em suas diversas linguagens, como simples estratégias de aprendizagem ou, pior ainda, de pensar nas linguagens artísticas como meras ferramentas auxiliares para modelos educacionais já propostos e, muitas vezes, ultrapassados.

Os grandes pensadores e, também, educadores tais como: Bergson, Sartre, Deleuze, Simone de Beauvoir, Bachelard, Foucault, Merleau-Ponty, Ricoeur, Paulo Freire, Haroldo de Campos, Stephen Hawking e tantos outros que poderíamos enumerar, há dezenas e dezenas de anos sempre souberam que as Artes, certamente incluindo a Literatura, tiveram um papel fundamental para o exercício do pensamento e, fundamentalmente, para a criação de teorias renovadoras. Transgressoras.

Os verdadeiros expoentes da humanidade e da Educação sempre souberam que as Artes não são meras atividades de deleite ou entretenimento. Mas sempre pensaram as Artes enquanto produtoras de conceitos e problematizações importantes, por diversos momentos, quase insondáveis, no que tange à intuição (de forma fundamentada), assim como seu papel na questão da estética, naturalmente, incluindo a Educação. Não se deve esquecer que as Artes sempre caminham à frente. Ulteriormente, a lógica (seja ela qual for) com teorias e possíveis metodologias. Em especial, aquelas que não petrificam a arte do pensamento. Nunca é demais lembrar: a gramática acontece depois de Homero. A teoria do romance depois do romance. As partituras surgem depois das canções e assim por diante.

Nessa medida, o nosso entrevistado deste número é o Prof. Dr. Juliano Casimiro de Camargo Sampaio da Universidade do Tocantins (UFT). Na entrevista fala, entre tantas outras coisas, de seu percurso profissional e de quanto a Arte Teatral foi fundamental em sua vida. Desde a infância. Fala-nos, inclusive, de suas experiências felizes envolvendo, prioritariamente, a linguagem teatral e a Educação. 
Integrando o dossiê, o artigo da Dra. Lucia Santaella e Clayton Policarpo discute a confluência das linguagens que nos permeiam. O quanto o surgimento de novas linguagens interfere em nossa percepção. Os autores nos oferecem uma análise aguda sobre o impacto das diversas tecnologias de comunicação em relação, principalmente, às questões que envolvem a leitura e os receptores. Procuram definir o leitor imersivo, o leitor ubíquo e o papel da estética do conhecimento.

No artigo da Dra. Catarina Justus Fischer há uma importante elaboração, reflexiva, a respeito da linguagem musical. A autora propõe, a partir, em especial, de suas experiências na área da Educação, algumas alternativas que poderão ser um poderoso instrumento no que tange ao pensamento e, ao mesmo tempo, refletir a música sob perspectivas de uma abertura para a estética e para a sensibilidade. Lembra o quanto a música é uma linguagem poderosa, se pensarmos em questões que envolvem multiplicidade e simultaneidade.

O artigo do Prof. Dr. Celso do Prado Ferraz de Carvalho e Maurício Braz de Carvalho faz uma investigação a respeito do retorno do Ensino Musical à Educação Básica do Brasil. Nessa perspectiva, os autores analisam a importância da linguagem da música no processo de construção social da escola pública brasileira.

O texto Folhetos de cordel no ensino de lingua materna: A aula de leitura revisitada, do Prof. Dr. Linduarte Pereira Rodrigues faz uma análise da literatura de cordel no que tange métodos e práticas para as aulas de língua portuguesa.

Posteriormente, os artigos que acompanham o dossiê trazem contribuições significativas para que se possa pensar não somente metodologias e modelos aplicados à Educação, mas, inclusive, espaços de muita reflexão sobre as práticas e experiências docentes que não indicam, apenas, modelos e receitas. Indicam o quanto a criatividade e sensibilidade devem integrar o percurso docente.

As resenhas publicadas neste número são verdadeiros convites de leitura. Instigantes. Provocativas. Apontam, mais do que nunca, a necessidade de acompanharmos as publicações mais recentes. Não somente leituras específicas da área. A Educação, acima de qualquer coisa, deve dialogar com diferentes instâncias do conhecimento. Diante disso, as duas resenhas apresentam obras que vão além do conteúdo delas mesmas. Demonstram claramente que a literariedade (dos livros resenhados) é o ponto fundamental de obras ensaísticas. Revelam um estilo singular e aberto. Ou seja, a forma, o ritmo, o deslocamento da pontuação 
e, consequentemente, da sintaxe. Demonstram que nada vale um conteúdo sem aquilo que definitivamente singulariza a autoria, que, por sua vez, define a tão sonhada autonomia intelectual. Com isso quem ganha são os leitores. Acabam por compreender a importância de forma e conteúdo enquanto conceitos inseparáveis. Necessários.

Desejamos a todos uma boa leitura!

As editoras

Ana Maria Haddad Baptista

Márcia Fusaro 


\section{ENTREVISTA / INTERVIEW}




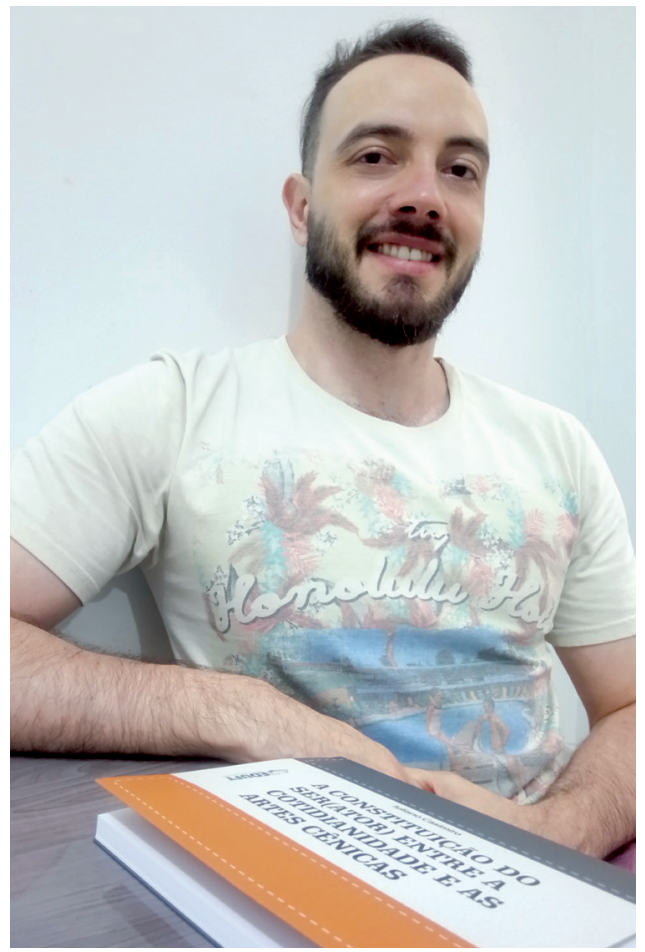

Educação, Intuição e Temporalidade

\author{
Entrevista com o professor \\ Juliano Casimiro de \\ Camargo Sampaio
}

Pós-doutoramento em Educação (UNICAMP - CORPO-TEMPORALIDADE: a intuição como conhecimento no ensino de teatro), Pós-Doutoramento em (INTENCIONALIDADE E AFETIVIDADE - A paisagem corporal-pessoal nos processos de construção de conhecimento no contexto de experiências corporais-estéticas), Doutor (AS ARTES CÊNICAS E O CONSTRUTIVISMO SEMIÓTICO-CULTURAL EM PSICOLOGIA - diálogos a partir da experiência corporal-estética em Composição Poética Cênica) e Mestre (DRAMATURGIAS CONSENSUAIS - a interação verbal no ato criativo) em Psicologia, pelo Instituto de Psicologia da USP; Bacharel em Artes Cênicas, pela UNICAMP; é professor adjunto em regime de dedicação exclusiva do curso de Licenciatura em Teatro da Universidade Federal do Tocantins (UFT) e professor permanente do Mestrado em Letras (Porto Nacional) da mesma universidade. Coordenador do CONAC (Grupo de pesquisa em Composição Poética Cênica, Narratividade e Construção de Conhecimento - $\mathrm{CNPq} / \mathrm{Brasil}$ ); presidente do Instituto de Arte e Cultura (UFT); responde como Diretor Artístico-Pedagógico do Eu-Outro Núcleo de Pesquisa Cênica (Tatuí-São Paulo - desde 2010), e como pesquisador do Laboratório de Interação Verbal e Construção de Conhecimento (IP/USP - desde 2008). Desenvolve pesquisas nas fronteiras entre as Artes Cênicas, a Psicologia (Construtivismo SemióticoCultural) e a Educação (em uma perspectiva filosófico-cultural), tomando como temas de interesse: Corporeidade, Composição Poética Cênica, Narrativa de Criação, Construção de Conhecimento e Desenvolvimento Afetivo-Cognitivo Humano. É sócio colaborador da Associação Brasileira de Pesquisa e Pós-Graduação em Artes Cênicas (ABRACE - GT: Ensino de Dança no Brasil) e membro-representante do Estado do Tocantins junto à Federação de Arte Educadores do Brasil (FAEB). 


\section{Dialogia: Poderia falar um pouco a respeito de seu percurso acadêmico e, sobretudo, profissional?}

Juliano Sampaio: Esse é um tema que não dá para começar na universidade. Recentemente, em artigo ainda por publicar, realizei uma intensa retrospectiva sobre minha formação e as influências atuais da minha atuação profissional. Portanto, o assunto está pulsante em mim. Voltemos ao passado. Comecei aos sete anos um curso de teatro oferecido no SESI-Sorocaba, sob condução de Edméia Pereira. Estudante de escola pública, meu contato com teatro havia acontecido poucas vezes nas excursões escolares. Mas a linguagem já me encantava verdadeiramente. Na primeira oportunidade, lá estava eu "fazendo teatro". Mas o que isso tem de relação com a questão que se coloca? Vejamos. Meus anos na prática teatral no interior de São Paulo me fizeram perceber que costumeiramente dois grupos de pessoas se envolviam com teatro no interior: 1 - pessoas que não tinham formação específica e atuação profissional, mas que iam tateando saberes sobre a linguagem, mantendo, no mais das vezes, um caráter dito amador para as produções; 2 - pessoas que tentavam a vida profissional nos grandes centros, não eram bem sucedidas e voltavam para o interior, frustradas, geralmente, para fazer um teatro comercial com ínfimo valor artístico, desvinculado das tendências a ele mais contemporâneas etc. . .

Felizmente, pude conviver com um grupo de artistas, no Sesi, que não se enquadravam a nenhum dos dois conjuntos de pessoas que citei agora. Isso me deu um propósito. Estava certo de que queria me formar em uma importante universidade, me graduar em teatro e voltar a trabalhar com e para o interior do Estado. E assim o fiz. Concluí minha graduação em Artes Cênicas na UNICAMP e fui trabalhar com teatro no interior com e para pessoas das cidades do interior. Essa iniciativa dura até hoje. Coordeno o Eu-Outro Núcleo de Pesquisa Cênica, que cria espetáculos para espaços não edificados para fins teatrais e se apresenta em pequenas e médias cidades do interior de São Paulo, preferencialmente, ainda que façamos também apresentações em grandes centros.

Outro aspecto relevante do meu percurso foi a minha necessidade, enquanto criança, de ter mais contato com teatro na educação básica. Lembrando dos meus próprios anseios, escolhi profissionalmente participar de projetos em ONGs e em programas e projetos de escolas públicas (no interior do Estado de São Paulo), tentando criar e potencializar contatos de crianças com a linguagem teatral. Em 
pouco tempo já estava com mais de 30 turmas entre trabalhos com ONGs, aulas de teatro em escolas públicas e aulas de teatro em escolas particulares.

A docência em teatro me inquietava muito. Eu não conseguia deixar de pensar na relação entre a experiência que eu tive com teatro na infância e adolescência e o adulto que eu era naquele momento. E essa reflexão sobre o que mobilizava em mim (e nos meus alunos) a experiência em teatro me levou à psicologia. Fiz um longo percurso de formação em psicologia, que envolveu formação em psicanálise (PUC-SP), mestrado, doutorado e pós-doutorado (USP).

Conforme as pesquisas iam avançando me dei conta de que meu verdadeiro objeto de estudos era uma questão, que foi se modificando durante o tempo, mas que em sua essência era a mesma: Qual a função do teatro na educação básica brasileira? E isso me levou a duas questões complementares: 1 - Que naturezas de conhecimentos existem nas experiências teatrais?; 2 - Como se dá o desenvolvimento afetivo-cognitivo de pessoas em experiências teatrais constantes? Mais recentemente, decidi estudar as naturezas de conhecimento do e no fazer teatral na escola, e para tanto, concluí um segundo pós-doutoramento, esse em educação na UNICAMP.

Minha dedicação ao interior do Estado de São Paulo me levou a querer explorar outros lugares fora dos eixos principais de criação, veiculação e experiência teatral. Em uma oportuna chance, abriu um concurso para professor de teatro na Universidade Federal do Tocantins. Eu fiz o concurso e já estou na UFT há mais de 6 anos. Nessa Universidade fundei o Laboratório de Pesquisa e Extensão em Composição Poética Cênica, Narratividade e Construção de Conhecimento (CONAC), cujas informações podem ser obtidas no sítio eletrônico www.conac.net. O CONAC se estrutura como espaço de experimentação de criação cênica, de estudos teóricos e, em 2018, estamos executando um projeto de escola laboratório para o ensino no componente curricular arte. A ideia é tentar reproduzir o mais próximo possível as condições da docência em arte na Educação Básica Pública. Alunos com idades entre 04 e 10 anos são atendidos no projeto. Trata-se de uma experiência tripla: 1 - 240 alunos em 6 turmas fazem aulas de arte (teatro), por mim ministradas; 2 - os 240 alunos discutem comigo um processo de criação de espetáculo teatral para crianças, a ser encenado pelos atores do CONAC; 3 - 40 professores das redes estadual (TO) e municipal (Palmas-TO) de ensino e 20 alunos da licenciatura em teatro da UFT acompanham as atividades de docência e discutem comigo as propostas e resultados. Com a escola laboratório, o principal 
objetivo é reestabelecer os laços necessários entre demandas das comunidades, formação continuada de professores e realidade da educação básica.

Duas outras experiências foram bastante relevantes para o caminho profissional que eu segui e que gostaria de indicar aqui. Primeiro, minha atuação no ensino técnico em teatro no Conservatório Dramático e Musical de Tatuí; experiência que me fez fortalecer meu desejo por formar pessoas que trabalhassem séria e profissionalmente com teatro no e para o interior de São Paulo. A segunda experiência é a participação na elaboração do projeto original da SP Escola de Teatro - Centro de Formação das Artes do Palco. Fiquei à época responsável pela elaboração do projeto de difusão cultural da Escola e pela coordenação do setor. Essa segunda experiência me fez entender que mesmo em grandes centros há sempre uma vasta periferia que merece grande atenção. Por desdobramento, comecei a refletir e me interessar por periferias de lugares que já são eles mesmos periféricos, em certos sentidos. E isso tem me movido nos projetos atuais por meio da pergunta: como favorecer deslocamentos entre centro e periferia nos projetos que desenvolvo? Esse percurso de formação e atuação foi me conduzindo a uma proposta de pesquisa estética que tenha como foco as relações humanas e, sobretudo, a complexidade dos sentimentos humanos. A exploração dessa temática tem sido feita por mim com meus companheiros de trabalho por meio de experimentações em espetáculos intimistas. Atores e públicos próximos, compartilhando humanidade, aspecto que também é primordial nas minhas escolhas e práticas em sala de aula: eu ouso dizer que eu busco formar professores para e pratico, de alguma forma, uma aula igualmente intimista.

Dialogia: Qual a sua perspectiva diante da Educação no Brasil em suas mais variadas dimensões? Você acredita que a médio prazo a nossa Educação possa alcançar níveis mais desejáveis em relação a outros países?

Juliano Sampaio: Enquanto operarmos segundo um modelo tecnicista de educação, que, antes de formar para a vida, busca formar para o mercado de trabalho, não acredito que teremos significativas mudanças. Modelo esse que deriva, em grande medida, do regime militar, com sua bandeira de formação de capital humano para o desenvolvimento econômico, ou seja, para o mercado de trabalho. 
Às vezes creio que o senso comum acredita que apenas maiores investimentos financeiros em educação seriam suficientes para mudar o mapa atual da formação no Brasil. Claro que a ampliação dos investimentos é urgente, mas se a permanência de uma pessoa no espaço escolar representar e funcionar descolada da vida cotidiana, realmente acho que tendemos a piorar as coisas com o tempo, independente dos valores investidos.

A especialização cada vez mais presente na educação básica, inclusive segundo o modelo em implementação no atual governo, tende a desviar ainda mais o foco da educação e a retroceder em alguns aspectos quanto aos avanços conquistados já no final da década de 1990, com os Parâmetros Curriculares Nacionais. Dizer que um jovem com seus 14 ou 15 anos já tem plena consciência da área em que quer atuar é ser, para dizer pouco, inocente. Além do que, se constrói, ou melhor, se reafirma com essa proposta a ideia de que não é a pessoa o foco da formação, senão o profissional que ela será um dia. Infelizmente, essa ideia não está muito distante da inapropriada pergunta que costumeiramente se faz às crianças: "O que você quer ser quando crescer?". Pergunta que deixa ver a descrença na criança como alguém que já é; que deve se voltar prioritariamente para isto que ela já é; e que desabilita a infância enquanto uma categoria social.

Não raramente nos deparamos com discursos da mesma ordem sobre a formação de professores. É comum que se espere que a educação continuada dê conta daquilo que a formação inicial não consegue abarcar, ainda que deva fazê-lo. Ou ainda, que são as pós-graduações que devem formar pesquisadores e não, outra vez, a formação inicial.

Leopoldo Waizbort, em seu texto "Glosa sobre a universidade, a formação e as disciplinas do saber, por ocasião de um concurso universitário”, vai além, e afirma que a formação básica no Brasil passou da deformação (formação do especialista) para a diplomação em massa. Quanto à formação de professores, especificamente, ainda temos a cultura universitária se sobrepondo à cultura escolar. Poucos são os casos em que percebemos projetos de cursos de licenciatura que tomam a realidade da escola, realidade concreta, não aquela idealizada, como ponto de origem das propostas de formação. É como se a Escola devesse se adequar à universidade e não o inverso, ou, o que seria ainda melhor, achar lugares de convergências e cooperação para a melhoria de ambas.

Durante os últimos anos, a partir de projetos de alguns orientandos e de meu pós-doutoramento em educação, analisei Projetos Políticos Pedagógicos de 
Licenciaturas das Universidades Federais Brasileiras. Foi assustador confirmar que ainda trabalhamos na formação de professores segundo um modelo que acrescenta à formação do bacharelado algumas disciplinas tidas como pedagógicas. E que a articulação dos conhecimentos específicos da área e a prática docente acontece, na maioria dos casos, apenas nos estágios supervisionados.

Ainda estamos operando a prática docente como se ela seguisse a lógica simplista do ensino de conteúdos. Associada à perspectiva conteudista, encontramos, para piorar a situação, a formação como adestramento: instrumentalização e disciplina do corpo. E mesmo com tudo isso, e talvez essa observação pareça muito romântica, não advogo pela falência da Escola. Contra essa tempestade de que falei, ainda existem zonas de resistência. E, nós, formadores de professores, devemos encontrar nossos caminhos para fortalecer essas zonas que já existem e possibilitar a criação de outras. É de dentro da prática educativa, do espaço escolar, claro, com apoios de diferentes ordens provenientes de instancias externas à escola, que a mudança será possível. Não acredito no contrário.

\section{Dialogia: Arte e Educação é um entrelaçamento que poderia ser perfeito. Qual sua posição diante disso?}

Juliano Sampaio: Se não se tiver clareza de porque a arte está inserida na educação, acho difícil que cheguemos a esse entrelaçamento perfeito. Em um dos componentes curriculares sobre minha responsabilidade na Licenciatura em Teatro da UFT, costumo perguntar aos discentes: Por que ensinar teatro na escola? Algo que não me surpreende mais, ainda que me incomode muito, é que a resposta tende a ser "porque a arte melhora as pessoas", "porque com arte o mundo se torna melhor"; ou, a que para mim é a pior das três respostas, "porque as crianças precisam conhecer o teatro".

Há uma inocência que envolve o tema de que a arte nela mesma já é benéfica à formação da pessoa, ou melhor, que é sempre uma experiência com valência positiva. Será mesmo? Pensemos quantas pessoas que tiveram contato com alguma das linguagens no espaço escolar e que hoje não a suportam. Ou ainda quantas vezes, em nome de atividades artísticas, soubemos, fizemos ou vimos atividades absurdas, como colar esponja de aço como cabelo de meninos e meninos desenhados em papéis para comemorar o dia da consciência negra etc. 
Em um Dossiê da revista Teatro: criação e construção de conhecimento, levantei esse tema com uma questão que para mim é essencial e que, se naquela ocasião se relacionava diretamente com o ensino de teatro, pode-se facilmente expandi-la para a docência das outras linguagens artísticas: "Que metodologia para que teatro [arte] em que escola?". Essa que deveria ser uma das questões fundamentais da discussão sobre a inserção da arte e das linguagens artísticas no ambiente escolar, quase nunca assume lugar de relevância nas práticas, discursos e pesquisas sobre o tema.

Venho me empenhando cada vez mais em investigar "quais as funções do ensino de arte, em especial, no meu caso, de teatro e dança, na educação básica brasileira?". É recorrente que se pense as metodologias de ensino das linguagens específicas desvinculadas das estéticas que deram origem a elas. Ninguém cria um método para o ensino de algo sem ter em mente o que vem a ser este mesmo algo. Em arte isso implica dizer que se reconhecem estéticas que pertencem à linguagem e uma gama muito grande de coisas que não se enquadram ao que se reconhece como determinada linguagem.

Ao menos, já demos significativos passos para o campo da arte na educação ao deixar de considerar a arte enquanto atividade para integrar o conjunto de áreas de conhecimento. Mas ainda é bastante raro que uma escola tenha em seu quadro de professores, docentes de todas as linguagens artísticas especialistas formados nas respectivas linguagens.

Outro desencaixe se vê entre as proposições dos documentos oficias em relação ao ensino de arte e as condições e realidades de atuação profissional. Os Referenciais Curriculares Nacionais para a Educação Infantil estabelecem as artes visuais e a música como eixos de trabalho para o objetivo maior da educação infantil: Formação Pessoal e Social e Conhecimento de Mundo, por exemplo. Vejam que o documento não considera as quatro linguagens como essenciais, apenas duas, tampouco a arte como campo de saber; as artes visuais e a música configuram eixos de trabalho, na mesma direção de identidade e autonomia, por exemplo. Teatro e dança aparecem diluídos no eixo de trabalho intitulado movimento.

O modelo triangular: fazer, apreciar, refletir, é a base da arte na educação no Brasil. Mas a indicação não passa disso: fazer pra quê? Apreciar o quê e pra quê? Refletir sobre o quê, de que ponto de vista, com que finalidade? São questões costumeiramente secundárias. De modo geral, são jogadas fora as especificidades de cada linguagem e da arte como todo como campo de exploração de si e do 
mundo. O mundo tende a ganhar cada vez mais espaço nas discussões sobre a inserção da arte na escola. Mas a pessoa ainda recebe atenção precária.

Por exemplo, o psicólogo genético Heinz Werner já comprovou em seus estudos que o aparecimento dos jogos dramáticos na infância tende a marcar um momento de declínio das transformações fantásticas de objetos e de partes do corpo. Para o psicólogo esse declínio tem significativas implicações negativas para a capacidade de abstração e da sensibilidade da pessoa em relação ao mundo. Ainda que isso já esteja bastante claro nas pesquisas do autor, os professores de teatro seguem ignorando esse tipo de situação e tendem a incentivar cada vez mais os jogos dramáticos, que tendem aos problemas da pessoa com o mundo, deixando de lado os jogos de transformações fantásticas de objetos, que podem ser amplamente explorados no contexto das aulas de arte.

Outro aspecto relevante é que mesmo os professores de arte seguem presos a um padrão epistemológico que tem a inteligência como foco, com trabalhos que primem pela resolução de conflitos pelo encontro de respostas alternativas a questões cotidianas. Henri Bergson tem uma obra completa que nos faz pensar em outras naturezas de conhecimento, entre eles, e principalmente, o conhecimento intuitivo, que, diferente do que se pensa, pode ser, segundo o autor, expandido em presença e potência no nosso cotidiano; o filósofo deixa claro em suas obras que não há contexto melhor para esse tipo de exploração e desenvolvimento do que as artes.

Poderíamos ainda pensar as funções tidas como mentais (mas que já se sabe que não o são exclusivamente): percepção, memória, imaginação etc. Essa última com ampla produção teórica e de análises de práticas na psicologia cultural, por exemplo. Todo o discurso sobre esses aspectos do desenvolvimento humano segue sendo tratados de modo raso por muitos teóricos da área. E o senso comum de que basta fazer arte, ver arte e falar sobre arte para se ter bons "resultados" ganha cada vez mais força. Claro que existe uma celeuma histórica entre a arte e a psicologia. O distanciamento foi importante historicamente para a constituição da arte como campo de saber próprio, em si, digamos. Mas passou da hora de se acabar com esse tipo de distanciamento. Bem menos raras são as aproximações com a filosofia. Mas, devo dizer, pelo que tenho visto, sempre circulando por um grupo de teóricos específicos e de mesma matriz teórica e metateórica.

Outro documento oficial, Os Parâmetros Curriculares Nacionais para o Ensino Fundamental: Arte, estabelece sete objetivos gerais para o ensino de arte, sendo 
apenas um relacionado com a pessoa: aprender a expressar-se em arte; todos os outros estão associados a experimentação de materiais, conhecimento histórico e social sobre a arte, artistas e movimentos artísticos. Evidentemente que esses conteúdos são importantes para a formação holística da pessoa, mas me parece bastante redutor em relação ao que poderia ser o ensino de arte no Brasil. Como venho afirmando nos meus trabalhos, é necessário devolver a pessoa para ela mesma, permitir que experimente a alteridade de si para si mesma, que possa ampliar sua capacidade de atribuir sentidos às coisas do mundo sem, necessariamente, atrelá-los aos significados cognitivos, explorar sua corporeidade, no sentido da fenomenologia de Merleau-Ponty (para referenciar apenas com um autor), e não há melhor contexto para tudo isso do que a arte. E não adianta dizer que o foco está no processo e não no resultado, se processo é sempre processo para algo, e se não se tem certeza do que vem a ser esse algo; ou se se toma este algo como a obra de arte (produto). Talvez estejamos dando um passo adiante com uma indicação específica da Base Nacional Comum Curricular: o documento traz claramente a necessidade da dimensão da estesia nas experiências do componente curricular arte. "Essa dimensão articula a sensibilidade e a percepção, tomadas como forma de conhecer a si mesmo, o outro e o mundo. Nela, o corpo em sua totalidade (emoção, percepção, intuição, sensibilidade e intelecto) é o protagonista da experiência (p. 193).” Meu problema está em não se entender, pelo menos é o que eu venho advogando sobre, que todas as outras dimensões deveriam estar postas em função dessa. Ou seja, criar, criticar, expressar, fruir e refletir deveriam ser os caminhos pelos quais é possível verdadeiramente se valer das especificidades das linguagens artísticas para ampliar a dimensão estesiológica da vida. Este é para mim o verdadeiro motivo de se inserir a arte como área de conhecimento na educação. Todos os outros são estratégicas metodológicas, procedimentais, como queiramos, para se chegar a esse fim: ser protagonista em seu processo pessoal de conhecer a si mesmo, a natureza e o mundo, como constitutivos de um processo de coevolução. Um leitor atento vai perceber que quando a BNCC trata das competências específicas de arte para o Ensino Fundamental, a pessoa desaparece, ao menos é ocultada, e a grande valia recai sobre a historicidade e a sociedade, infelizmente.

Mas veja, eu sou otimista em relação a mudanças possíveis, do contrário já teria desistido no caminho. Tenho alguns bons parceiros, da arte, da educação, da filosofia e da psicologia, que tem me feito ver a importância de manter a linha de 
trabalho que sigo como uma das zonas de resistência a partir da qual e de outras semelhantes algum cenário futuro diferente e melhor possa ser aventado.

\section{Dialogia: Quais são as maiores dificuldades que encontra em seu universo educacional?}

Juliano Sampaio: A formação superior, com certeza, e o desgaste dos colegas da educação básica, não sem motivos, claro. O primeiro dos problemas já indiquei em resposta anterior. Vou ampliar a discussão um pouco aqui. Mas antes, quero me atentar para o segundo ponto: professores da educação básica.

A rotina a que estão submetidos os professores da educação básica abre pouquíssimo espaço para a qualificação continuada, a prática artística dos docentes e a pesquisa. Professores de arte, no mais das vezes, deixam de criar, de ter projetos estéticos e poéticos pessoais. Evidentemente que a rotina escolar, de que já falei, dificulta a manutenção das atividades pessoais de criação artística. Mas também há certa ideia de que professor de arte não precisa ser artista. Concordo que não o precise ser como profissão principal, digamos. Mas não acho que seja possível ensinar arte sem ser um conhecedor profundo da linguagem. Não se trata de discorrer sobre experiências de outros sobre e com arte. Isso faz parte do componente curricular arte: mas a feitura, em certa medida, é essencial.

Tenho afirmado que o professor de arte precisa ter uma formação inicial e continuada com grande volume de experiências artísticas para que possa operar sua aula com arte e não transferir para os alunos da educação básica essa ânsia pela criação. O que quero dizer é que a arte é a área de conhecimento e ao mesmo tempo o mais adequado método de ensino nesse campo. Mas só ensina em e com arte alguém que tenha manejo com a linguagem. E manejo com a linguagem exige experiência.

Não sou favorável a criação de novos rótulos bem comuns na nossa contemporaneidade como professor-artista; pesquisador-artista-docente. Acho que se trata simplesmente de uma carreira profissional como outra qualquer. E a carreira é a de professor de arte. Agora, as exigências dessa carreira é que precisam ser repensadas. Entendo o movimento histórico das propostas de nomenclaturas para a função, mas não acho que proponham avanços significativos para a solvência dos conflitos entre formação, rotina escolar e atuação profissional. 
Se queremos mudanças expressivas, creio que está mais do que na hora de professores de arte na escola terem parte de seu tempo destinados para ateliês de criação, que, se podem participar outras pessoas, deveria ser um espaço prioritário para desenvolvimento da poética pessoal do próprio professor.

Quanto à formação, enquanto, como já apontei antes, conhecimentos específicos da linguagem e conteúdos pedagógicos só se associarem, e de modo abrupto, no estágio supervisionado, não acho que avançaremos com essa questão. A Resolução CNE/CP 2/2015 (Ministério da Educação; Conselho Nacional de Educação; Conselho Pleno) já prevê que aos alunos devem ser ofertadas possibilidades de contato pedagógico anteriormente ao Estágio Pedagógico. Fato que raramente se realiza nas Licenciaturas, a não ser por projetos especiais não previstos em seus Projetos Político-Pedagógicos de Curso. Por fim, não se deve fechar os olhos para uma realidade avassaladora. A legislação exige que as quatro linguagens sejam ofertadas em algum momento da educação básica; professores não possuem mais formação polivalente; as escolas só contam com um ou dois professores de linguagens diferentes (quando contam com algum) e, portanto, atuam de modo polivalente.

Formação e prática profissional, nos parâmetros que temos hoje de capital humano nas escolas, são absolutamente discrepantes. Não estou afirmando a necessidade da volta à formação polivalente, mas também não dá para ignorar que se resolveu uma ponta do problema, a formação superior em linguagem específica, sem solucionar a outra, a atuação do professor de modo polivalente no componente curricular arte.

Dialogia: Que mensagem enviaria, nos dias de hoje, para alunos e professores do Brasil?

Juliano Sampaio: Descubramos perto de nós, na nossa vizinhança, quais são as zonas de resistência no campo da Educação. Entendamos como podemos fortalecer e ampliar essas zonas. Criemos as nossas próprias. Pensemos a política no seu sentido mais amplo, por meio de associações, representações legais, federações etc., mas atentemos, sobretudo, para a micropolítica: aquela que pode trazer transformações pontuais ou mais duradouras nos nossos contextos imediatos. Reflitamos sobre o porquê de sermos professores. Quais histórias sobre a educação você gostaria de ter para contar em uma 
roda de amigos daqui uns 10 anos? E o que você tem feito para que essas histórias sejam possíveis? E, antes de mais nada, sejamos parceiros e não concorrentes. Isso tem aniquilado muitas almas que poderiam fazer grande diferença se não fossem os empecilhos em forma de gente. 
DOSSIÊ TEMÁTICO: Educação e Artes / THEMATIC DOSSIER: Education and Arts 


\title{
A estética do conhecimento nas redes digitais
}

\author{
The aesthetics of knowledge in digital networks
}

\author{
Clayton Policarpo \\ Doutorando e mestre em Tecnologias da Inteligência e Design Digital \\ (TIDD). Integrante dos grupos de pesquisa TransObjetO (TIDD - \\ PUC-SP) e Realidades (ECA - USP), São Paulo, SP - Brasil \\ clayton.policarpo@gmail.com
}

Pesquisadora 1A do CNPq. Doutora em Teoria Literária. Professora titular no Programa de Pós-Graduação em Comunicação e Semiótica e no Programa de Pós-Graduação em Tecnologias da Inteligência e Design Digital (TIDD), ambos da PUC-SP, São Paulo, SP - Brasil lbraga@pucsp.br

Resumo: Frente ao atual estado de confluência de linguagens, propiciado pela disseminação de tecnologias de comunicação e dispositivos móveis, a produção e recepção de conhecimento tende a extrapolar os limites disciplinares, antes impostos por um modelo pautado pela hegemonia do livro impresso e presença do professor em sala de aula, para adquirir contornos inéditos. 0 presente estudo toma como ponto de partida as definições de leitor imersivo e leitor ubíquo, propostos por Santaella, para alçar uma compreensão acerca do potencial estético do conhecimento e aprendizado no atual estado de convergência das redes. São realizadas aproximações entre uma aprendizagem ubíqua e os conceitos de conhecimento intuitivo e conhecimento tácito, de modo que é possível identificar um caráter estético inerente à produção de conhecimento que utiliza de redes digitais.

Palavras-chave: redes; leitor ubíquo; conhecimento tácito; estética do conhecimento.

\begin{abstract}
Given the current state of confluence of languages, propitiated by the dissemination of technologies and mobile devices, the production and reception of knowledge tends to extrapolate the disciplinary limits imposed by a model based on the hegemony of the books and the presence of the teacher in the classroom, to acquire unprecedented contours. The present study takes as its starting point the concepts of immersive reader and ubiquitous reader, proposed by Santaella, to raise an understanding about the aesthetic potential of knowledge in the current state of convergence of networks. Approaches are made between a ubiquitous learning and the concepts of intuitive knowledge and tacit knowledge, so that it is possible to identify an aesthetic character inherent in the production of knowledge that uses digital networks.
\end{abstract}

Keywords: networks; ubiquitous reader; tacit knowledge; aesthetic knowledge. 


\section{Introdução}

Embora as possibilidades hipermidiáticas já se insinuassem na mescla de linguagens, presente nos primeiros computadores, o texto escrito prevaleceu, durante anos, como formato padrão da internet. Foi só a partir do advento dos smartphones que as máquinas começaram a ganhar olhos, ouvidos e, aos poucos, imbuíram-se de inteligência para decifrar e manipular conteúdo em imagem, som e vídeo.

Frente à expansão do uso de tecnologias digitais e em rede, a produção e recepção de conhecimento tende a extrapolar os limites disciplinares, antes impostos por um modelo pautado pela hegemonia do livro impresso e presença do professor em sala de aula, para adquirir contornos inéditos. Hoje, é mais simples comunicar-se, seja com humanos ou máquinas, através de imagens e sons capturados por dispositivos, do que por palavras escritas.

O presente estudo toma como ponto de partida as definições de leitor imersivo e leitor ubíquo, propostos por Santaella $(2004,2013)$, para alçar uma compreensão acerca do potencial estético do conhecimento e aprendizado no atual estado de convergência das redes. Em uma cultura em que slogans e memes parecem ter mais poder e aderência do que argumentos discursivos (MANJOO, 2018), é crucial investigar as transformações socioculturais e cognitivas decorrentes do uso de tecnologias dotadas de potencial multimídia.

\section{Do livro às redes móveis}

Com a disseminação das tecnologias de linguagens nas últimas décadas, não foram poucos os rumores e profecias acerca do fim do livro. Mesmo diante da evolução dos meios de massa, o artefato de leitura, que se popularizou a partir da prensa gutenberguiana, continuou a deter a hegemonia na transmissão de conhecimento durante todo o século XX. Embora o cinema, rádio e emissoras de TV sempre tenham exercido grande atração sobre seus receptores, era evidente uma divisão de áreas pouco comunicantes entre si no conteúdo transmitido: de um lado, a aquisição de conhecimento segundo o modelo da educação formal, baseado na cultura do livro; e, de outro, o entretenimento e a distração, dos meios de massa figurando como protagonistas (SANTAELLA, 2014, p. 17). 
A partir da hipermídia com sua associação de diferentes linguagens, somada à possiblidade de compartilhamento de conteúdo e interação dos usuários, esse modelo opositivo entre aprendizado e entretenimento começou a ruir. Com seu protagonismo disputado por outras plataformas e linguagens, a condição do livro passou a ser questionada, enquanto instrumento essencial na formação e na transmissão de conhecimento.

O discurso do marketing corporativo é convincente e uma gama de produtos e ferramentas promete, diariamente, revoluções nos modos de publicação, distribuição e pensamento que trazem sempre algo novo e que desterram tudo aquilo que lhes é anterior. A lógica da novidade iminente draga não só o passado, mas o próprio presente, arremessando-nos em um estranho estado de expectativa de um pós-futuro que nunca chega, mas que se promete a milhões e milhões de potenciais usuários globais (BEIGUELMAN, 2003, p. 10).

Parece haver indicadores relativamente seguros de que o texto não irá desaparecer, apesar da aparente retração da linguagem escrita, diante da efervescência de mídias audiovisuais na web. A história do conhecimento nos revela que a ascensão de novas tecnologias não decreta a extinção das suas antecessoras. Numa visão avessa às perspectivas apocalípticas, que em uma narrativa messiânica impõem um confronto entre fim e começo, e vislumbram uma inevitável substituição de dispositivos por suas versões subsequentes, o que observamos é uma recombinação constante entre diferentes mídias e meios. A linguagem e o pensamento humano se ajustam e se conformam às possibilidades oferecidas pelas tecnologias comunicacionais do seu tempo. As transformações promulgadas pelas tecnologias em rede são, sem dúvida, muito mais profundas que as geradas pelos dispositivos que lhes precederam. $\mathrm{O}$ avanço de aparatos digitais conduz a uma reconfiguração em um processo contínuo dos ambientes socioculturais, que até então pareciam bem demarcados no tempo, e também propicia uma ampliação exponencial da nossa capacidade de produzir e armazenar conteúdo.

A popularização de dispositivos móveis dotados de aplicativos e ferramentas de edição, graças à simplificação dos protocolos de acesso às redes, impele um circuito heterogêneo de produção e difusão de conteúdo multimidiático. Do 
hipertexto a uma cultura "pós-textual", que submete a linguagem escrita à competição com as imagens, sons e vídeos que pululam nas redes, é inegável que aí se instaura um novo paradigma nas relações entre linguagens. Diferente das gerações tecnológicas anteriores, que demandavam rituais demorados para acesso à rede, hoje, a conexão é a regra.

É fato que sempre lidamos com recursos não-verbais na apreensão de conhecimento. Diversas plataformas de comunicação em massa, por exemplo, os jornais, revistas, gráficos, mapas, sistemas de notações etc., já demandavam a associação de diferentes linguagens para a compreensão de seus conteúdos (SANTAELLA, 2014, p. 266). Mesmo no livro impresso já existem elementos paratextuais (modelos tipográficos, espaçamentos, numeração de folha) e eventuais imagens que compõem as páginas de uma publicação.

Nick Sousanis (2017), reconhecido como o primeiro pesquisador a concluir uma tese de doutorado em formato de história em quadrinhos (HQs) na Universidade Columbia, é um defensor da possibilidade de um conhecimento para além dos limites restritos do modelo discursivo. Ao optar pelos quadrinhos como suporte para a pesquisa, o autor integra planos de expressão e conteúdo no desenvolvimento de sua tese. A originalidade do trabalho de Sousanis reside na capacidade de estabelecer diálogos entre diferentes linguagens (verbal e visual) de forma que ambas atuem em interdependência. Para o autor, as HQs, enquanto meio de comunicação que reúne camadas distintas, seriam o suporte ideal para representar narrativas divagantes e cheias de intersecções (SOUSANIS, 2017).

O usual sempre foi manter palavras e imagens a uma distância "segura". Entretanto, a expressão em um meio estritamente discursivo tenderia, segundo o autor, a "aplainar" e distorcer o pensamento, condicionando-o a um domínio linear (SOUSANIS, 2017). As palavras sempre detiveram certo privilégio como modalidade explicativa, como a ferramenta para o pensamento. "A imagem, por outro lado, há muito tempo é segregada ao reino do espetáculo e da estética, marginalizada na discussão séria como mera ilustração que apoia o texto - nunca vista em pé de igualdade" (SOUSANIS, 2017, p. 54). Ao contrário, é tamanha a hibridização de linguagens no trabalho de Sousanis que citações e menções comportando apenas o aspecto verbal da pesquisa resultariam em tentativas falhas de conjugar as hipóteses do autor. "O entrelaçar proposital de linhas de raciocínio diversas cria um chão comum. Uma rica trama dimensional" (SOUSANIS, 2017, p. 37). 
Em 2015, de forma inédita, o Dicionário Oxford elegeu como "palavra do ano" um pictograma: o emoji definido como "rosto com lágrimas de alegria". A seleção, feita anualmente, parte de uma investigação das transformações na língua inglesa, e escolhe uma palavra ou expressão que tenha atraído atenção nos últimos doze meses. Tal palavra tende a refletir o ethos, humor ou preocupações daquele período em particular, além de ter um potencial duradouro como um termo de significado cultural. ${ }^{1}$ O emoji vencedor em 2015 foi finalista entre diversas palavras e termos (como "refugiado", "dark web", "economia compartilhada", "they"), e foi analisado em sua frequência global, tendo representado $20 \%$ de todos emojis no Reino Unido, e 17\% nos Estados Unidos.

A admissão de um elemento pictográfico como o termo mais representativo de um ano é um índice sutil de um novo modelo de comunicação. Como já exposto, é a partir das tecnologias em rede e, mais recentemente, dos dispositivos móveis, que fronteiras antes bem delimitadas entre as categorias de conteúdos começam a se desfazer. A evolução dos dispositivos móveis em uma cultura do compartilhamento favorece uma interlocução tecida em linguagens múltiplas. Fotos, áudios, vídeos, gráficos invadem de maneira insistente nossa experiência on(off)line.

As linguagens não textuais cujo uso estava condicionado a uma cultura de comedimento, hoje, ascendem ao status de protagonistas. De acordo com dados divulgados pelo The New York Times (MANJOO, 2018), cerca de 70 milhões de americanos escutam podcasts regularmente, e tendem a gastar cinco horas por semana com o formato; enquanto os jovens passam duas horas por dia assistindo a vídeos on-line (o Youtube afirmou em 2017 que um bilhão de horas de vídeos foram assistidos na página por dia). O levantamento divulgado pelo jornal também revela que mais de 800 milhões de pessoas usam a rede social Instagram por mais de 30 minutos diariamente. 0 sucesso de plataformas audiovisuais faz com que os grandes investimentos sejam direcionados para a área: a Netflix apresentou um plano para gastar 8 bilhões de dólares em um ano, enquanto a Apple planeja desembolsar 1 bilhão (MANJOO, 2018).

O cenário fica mais evidente quando constatamos que as inovações digitais mais proeminentes dos últimos anos são protagonizadas por câmeras, microfones, voz, ouvidos e olhos (MANJOO, 2018): assistentes virtuais acionados por voz, o leitor facial do iPhone, tecnologias dotadas de inteligência artificial para pesquisas de imagens ou para traduzir o idioma falado, dispositivos dotados de 
realidade aumentada etc. Em um caminho sem volta, linguagens tendem a se sobrepor e se complexificar, "o texto recua ao fundo enquanto o som e a imagem despontam como linguagem universal” (MANJOO, 2018).

\section{0 perfil cognitivo do leitor ubíquo}

Diante das transformações observadas nos campos cognitivos, perceptivos, sensórios e mesmo motores, Santaella (2004) estudou o perfil do usuário das redes a que deu o nome de leitor imersivo. Posteriormente, depois da crescente emergência dos dispositivos móveis, descreveu o perfil do leitor ubíquo (SANTAELLA, 2013). Tais definições são partes de uma classificação maior, que compreende quatro tipos de leitores: leitor contemplativo, leitor movente, leitor imersivo e leitor ubíquo, de modo a não negligenciar as tecnologias cognitivas anteriores ao digital e as configurações socioculturais que comportam.

O leitor contemplativo deriva de uma relação íntima entre o leitor e o livro impresso (SANTAELLA, 2004, p. 23); enquanto o leitor movente, sincronizado no ritmo urbano, é marcado pela lógica de consumo e pela emergência de um novo estatuto da percepção, fragmentada pela leitura de imagens em movimento e pelos cortes abruptos da linguagem cinematográfica e, depois, televisiva (SANTAELLA, 2004, p. 26-27).

O leitor imersivo, por sua vez, nasce com as redes digitais. É aquele que navega em informações reticulares, saltando entre conteúdos multimidiáticos. O leitor ubíquo, por outro lado, surge a partir da evolução de sistemas computacionais móveis, que permitem sincronizar a navegação interativa pelas teias de linguagens nas redes da internet com a mobilidade nos espaços físicos.

É essa ideia de estar sempre presente em qualquer tempo e lugar que interessa levar para a caracterização do leitor ubíquo, uma nova condição de leitura e de cognição que está fadada a trazer enormes desafios para a educação, desafios que estamos apenas começando a vislumbrar (SANTAELLA, 2013, p. 278).

Em trânsito pelo espaço físico da cidade, sendo afetado pelos seus estímulos, ao mesmo tempo que também perambula pelas infovias digitais, o leitor ubíquo 
conjuga traços do leitor movente e do leitor imersivo. A capacidade de presença em ambientes intersticiais evoca um estado de prontidão inédito.

Contudo, as facilidades proporcionadas pela disponibilidade de um conhecimento e aprendizado ubíquos, que podem ser obtidos em quaisquer ocasiões, eventualidades, circunstâncias e contextos, culminam em questões como a economia da atenção. Aberto a uma pluralidade de estímulos em um ambiente informacional complexo, o leitor ubíquo se vê impelido a responder tais impulsos por meio de uma cognição multitarefas (SANTAELLA, 2013, p. 280).

Han (2015) nos fala do pensamento multitarefas não como um progresso civilizatório, que nos tornaria aptos à realização de uma série de atividades concomitantes, mas como algo mais próximo de um "retrocesso". Segundo o autor, a atenção múltipla é amplamente disseminada entre animais em estado selvagem dispostos em seu ambiente natural: uma técnica de atenção indispensável para a sobrevivência, que permite alimentar-se e permanecer atento aos predadores. "O animal não pode mergulhar contemplativamente no que tem diante de si, pois tem de elaborar ao mesmo tempo o que tem atrás de si” (HAN, 2015, p. 32). Atividades que exigem uma percepção multitarefa geram uma atenção ampla, mas rasa, semelhante à atenção de um animal selvagem. "Só o demorar-se contemplativo tem acesso também ao longo fôlego, ao lento. Formas ou estados de duração escapam à hiperatividade" (HAN, 2015, p. 36).

Os grandes progressos da humanidade, dentre os quais podemos citar a filosofia e a ciência, devem-se a um exercício de atenção profunda e contemplativa (HAN, 2015, p. 33). Entretanto, atuar em um cenário protagonizado por tecnologias móveis e produção ubíqua de conteúdo não significa abdicar da capacidade contemplativa, mas conjugar as habilidades acumuladas desde o despontar da cultura dos livros com as possibilidades oferecidas pelo meio digital.

Jenkins et al. recorrem a uma interessante analogia com as habilidades que são exigidas a um fazendeiro e a um caçador (2010, p. 46 apud SANTAELLA, 2014, p. 281). Enquanto o primeiro deve completar uma sequência de tarefas que exige uma atenção localizada, o segundo "escaneia" uma paisagem complexa na busca de signos ou pistas. Se por um lado, a formação nas escolas sempre esteve pautada pelo perfil do fazendeiro, exigindo que os estudantes foquem em uma atividade por vez, em conteúdos distintos, as habilidades desempenhadas pelo leitor ubíquo tendem a coincidir com as do caçador (SANTAELLA, 2014). O desafio 
que se impõe é o de como alçar uma complementaridade entre as duas formas de atenção, de modo que não se sobreponham em importância.

Conforme foi colocado por Santaella (2014), os diferentes perfis de leitores não operam de maneira excludente. As habilidades específicas de cada leitor não anulam os demais perfis, mas contribuem "para a formação de um leitor provido de habilidades cognitivas cada vez mais híbridas e cada vez mais complexas" (SANTAELLA, 2014, p. 281). É a partir do surgimento de smartphones e tecnologias móveis, e impulsionadas pela audiência provinda das redes sociais, que as promessas multimídias ensejadas nos primórdios da web começam a ganhar corpo. A complexidade na transmissão e aquisição de conhecimento, observada no surgimento dos leitores imersivo e ubíquo, exige uma revisão de modelos antes exauridos e uma reprogramação mais complexa e integrativa do que podem supor os entusiastas de hard e software (SANTAELLA, 2014, p. 283). Tal revisão implica considerar que as transformações cognitivas, que operam na passagem de um tipo de leitor a outro e, mais especialmente, na sincronia contemporânea entre esses perfis, estão relacionadas com novos modos de aprender e de conhecer. De fato, um dos aspectos de maior relevância na classificação de tipos de leitores, desenvolvida por Santaella, encontra-se na abertura de caminhos que essa classificação abre para a consideração das transformações substantivas nos processos de aprendizagem e aquisição de conhecimento que vieram à tona com as redes digitais nas quais instaurou-se um tipo inédito de composição multilinguagens. Dessa composição decorre uma consequente quebra da hegemonia da cultura do livro e da linguagem verbal linear. Longe do que se pode negar apressadamente, as atuais formas miscigenadas de linguagens, além de se constituírem com qualidades estéticas inéditas, também são meios eficazes de produção, transmissão e aquisição de conhecimento. São essas questões que iremos examinar a seguir.

\section{Preâmbulo acerca dos modos de conhecimento}

Falar sobre a produção de conhecimento e aprendizado nas redes pressupõe um resgate da definição de conhecimento. Debruçar-se sobre um conceito repleto de ambivalências está longe de ser uma tarefa simples. O percurso aqui proposto é de caráter plural, e se faz valer de autores que estabelecem um diálogo possível, 
pouco sujeito a controvérsias, e que permite levar a questão para as redes e para a produção estética contemporânea.

Daveport e Prusak (1998) tratam o conhecimento a partir de uma definição dos conceitos de dado e informação. Em um contexto genérico, dado pode ser descrito como "conjunto de fatos distintos e objetivos, relativos a eventos" (DAVEPORT, PRUSAK, 1998, p. 26). Enquanto os dados em si não retêm qualquer significado ou relevância, a informação é constituída de dados interpretados dotados de relevância e propósito (DAVEPORT, PRUSAK, 1998, p. 29). O conhecimento, por sua vez, deriva da informação, em "uma mistura fluída de experiência emoldurada, valores, informação contextual e insight experimentado, a qual proporciona uma mistura para a avaliação e incorporação de novas experiências e informações" (DAVEPORT, PRUSAK, 1998, p. 33).

No campo filosófico, a discussão sobre as formas de conhecimento se dá pela gnosiologia e, em alguns pontos, converge com os estudos de Daveport e Prusak. Segundo Vita (1964), conhecer implica em apreender, com a mente, um objeto; apreensão esta que configura uma pluralidade de atos (VITA, 1964, p. 102-103). Em sua obra que conjuga um prelúdio para diversas questões da história da filosofia, o autor expõe três formas de conhecer: o conhecimento intuitivo, o conhecimento discursivo e o conhecimento compreensivo (VITA, 1964, p. 103). Enquanto o conhecimento intuitivo se apoia em uma apreensão imediata e direta do objeto, o conhecimento discursivo nos dá o objeto mediato e indiretamente, como o término de um raciocínio. Já o conhecimento compreensivo figuraria como uma subespécie do modelo intuitivo, um ato pelo qual se apreende o psíquico através de suas múltiplas exteriorizações (DILTHEY apud VITA, 1964 p. 104).

A partir de uma classificação do conhecimento, Miguel e Santaella (no prelo) propõem que, embora as interpretações de conhecimento difiram entre si, é possível considerar uma estrutura para discorrer sobre o tema que contemple: (a) as suas dimensões epistemológicas - tácito, implícito, explícito, ou simbólico, corporificado, mentalizado, aculturado, (b) as suas dimensões ontológicas - individual, coletivo e consciente, inconsciente (MIGUEL e SANTAELLA, no prelo). As autoras ressaltam que "uma terceira discussão pode ser localizada no conhecimento, enquanto ato de conbecer, enquanto processo e o conbecimento propriamente dito, enquanto produto final desse processo."

Nas últimas décadas, questões acerca da possibilidade de outras dimensões do conhecimento permeiam diversas áreas, e têm encontrado solo fértil para o 
debate, inclusive, no campo da ciência. São diversos os estudos que passaram a incorporar estratégias não discursivas em metodologias de pesquisa, em especial em investigações empíricas e métodos etnográficos que tendem a observar a sociedade "de fora". Em Ciência em Ação (1997), Bruno Latour propõe uma etologia do fazer científico, que evidencia os aspectos não explicitados e mesmo subjetivos na produção de conhecimento. Avesso à ideia de uma ciência que se volta para a busca de meros objetos estáveis e passíveis de reprodução, Latour direciona o seu foco de interesse para objetos instáveis em uma ciência inacabada e em processo (LATOUR 1997, p. 39). As pesquisas do autor, que adquiriram notoriedade em diversas áreas, somam-se ao coro de teorias que buscam uma releitura da produção intelectual e científica do nosso tempo.

Por um lado, a constatação das limitações do pesquisador, seja pela imprevisibilidade dos diversos agentes (humanos ou não) que constituem o processo de criação, ou por uma possível falência de um modelo limitante de pensamento, faz com que novas estratégias e metodologias adquiram relevância. Ao mesmo tempo que o aspecto ininterrupto da conexão tende a desestabilizar a hegemonia de modelo linear de pensamento, também impõe novas perspectivas de atuação que atravessam as mais diversas áreas. Da educação ao marketing são favorecidos diálogos que incorporam a multiplicidade de interesse de pesquisadores em abordagens interdisciplinares.

Embora o conhecimento resida em um território múltiplo, o aspecto explícito e passível de ser expresso de uma maneira racional sempre foi sobrevalorizado frente àquele que é gerado de um sentimento interno difícil de explicar. 0 modelo discursivo de conhecimento ditou a tônica de toda a produção científica e filosófica ao longo da história do Ocidente. Dada tal prevalência, a produção de conhecimento em outros meios, a exemplo da prática estética, parecia atrelada ao domínio do discurso, e dependente de uma estrutura verbal e argumentativa para sua legitimação (MERSCH, 2015, p. 8).

Para Maturana e Varela (2007) todo fazer é uma forma de conhecer. Os autores questionam a validação do conhecimento por seus aspectos meramente objetivos, enquanto a experiência humana é classificada como subjetiva e de menor importância. É do encadeamento entre ação e experiência, essa inseparabilidade entre ser de uma maneira particular e como o mundo nos parece ser, que os autores postulam uma não separação entre fazer e conhecer (MATURANA, VARELA, 2007, p. 31-32). 
A possibilidade de uma percepção que extrapola o raciocínio e a análise, por vezes, reside em um tipo de conhecimento que não sabemos que possuímos e, se perguntados, não saberemos como explicá-lo. O conhecimento tácito, termo cunhado por Michael Polanyi (1966, 2009), refere-se a tal conhecimento inefável, que não pode ser reduzido ao discurso e, portanto, impossível de ser compartilhado no domínio verbal. A tese de Polanyi, de que sabemos mais do que podemos dizer (ibid.), contrapõe paradigmas da ciência moderna que, na missão de se isentar de qualquer traço de subjetividade no processo de pesquisa, negligenciou uma dimensão tácita.

A percepção e o conhecer são elementos conectados. Toda dificuldade está na superação da dicotomia entre conhecimento prático versus conhecimento teórico, formando o que Polanyi denomina de "knowing", como resultado da integração de ambos, uma vez que todo conhecimento envolve uma ação humana (POLANYI, 1966, p. 7 apud MIGUEL e SANTAELLA, p. 5).

Polanyi nos fala do eventual desaparecimento de algumas coisas, no processo de percepção, para que, então, possamos "atender" a outras. O autor, a partir de uma linguagem da anatomia, pontua dois tipos de consciência, para exemplificar um ato de conhecimento tácito, sendo o primeiro tipo definido como proximal (subsidiário); e o segundo como distal (focal) (POLANYI, 2009, p. 10). Ambos modelos são mutuamente excludentes, enquanto direcionamos o foco para um deles, o outro vira subsidiário.

Ainda segundo Polanyi, na estrutura funcional da cognição tácita, precisamos aprender a confiar nos elementos em consciência subsidiária para atender ao nosso foco - nosso conhecimento sobre eles é tácito, indicando que sabemos mais do que nossa consciência nos revela (POLANYI, 1966, apud MIGUEL e SANTAELLA).

"Sob a forma de conhecimento tácito existem desde aspectos perceptuais até processos inconscientes e julgamentos de questões de valor, logo na dimensão axiológica" (VIEIRA, 2015, p. 149). Dentre as coisas que poderíamos conhecer desta forma, Polanyi cita fisionomias, formas geométricas, objetos externos percebidos pelos nossos sentidos. "O nosso corpo está envolvido na percepção dos objetos, e participa disso no nosso conhecimento de todas as outras coisas 
externas." Ademais, continuamos a nos expandir para o mundo, de modo a nos formarmos, do ponto de vista prático e intelectual, em um universo povoado por entidades, cujos detalhes interiorizamos para compreender o seu significado.

O conhecimento intuitivo possui sua dimensão tácita. "É claro que a atividade artística encara mais de frente as questões tácitas, sem a resistência que a maioria dos cientistas apresentam diante dela" (VIEIRA, 2015, p. 150). Aptos a lidar com a criação em uma linguagem não discursiva e repleta de ambiguidades, artistas tendem a explorar não apenas a realidade, mas as possibilidades do real em investigações capazes de integrar em diferentes graus dimensões implícitas e explícitas do conhecimento.

As diferentes bases de entendimento e modalidades de conhecimento não atuam de maneira isolada, mas em diálogo. "É visível que a atividade mental do ser humano é desenvolvida em um cenário formado pela mescla dessas várias formas de conhecimento, como um processo efetivamente sistêmico" (ibid.). Sob tal perspectiva, podemos dizer que não há conhecimento dissociado de seu contexto, ou que possa desconsiderar as condições e suportes em que foi concebido e divulgado. "O ato de conhecer ocorre de forma contínua, uma vez que os seres humanos criam conhecimento envolvendo-se com objetos, e grande parte desses conhecimentos é fruto do esforço humano para lidar com o mundo" (NONAKA e TAKAEUCHI, 1997 apud MIGUEL e SANTAELLA, p. 4).

Diante do exposto, fica evidente a maneira como o conhecimento tácito opera no caso do leitor ubíquo. De fato, o processo de aquisição de informação no aberto, em qualquer tempo e lugar, vai produzindo uma forma de conhecimento que se incorpora espontaneamente, sem que o agente se dê conta de suas próprias aquisições cognitivas.

\section{0 potencial estético do conhecimento nas redes}

Há um imperativo estético nas redes. Mediante as facilidades oferecidas pela rápida evolução de ferramentas tecnológicas, é amplificado um modelo de conhecimento que atua para além da hegemonia do formato discursivo tradicional.

Bentes (2007) propõe uma análise que contempla uma dupla abordagem: de um lado o devir midiático da comunicação e das artes, a partir da apropriação dos meios e dispositivos pelas práticas artísticas contemporâneas, extraindo 
das tecnologias seu potencial estético, "incorporando ou subvertendo-os em proposições artísticas". E o devir estético das mídias, "com a desterritorialização e circulação das imagens, que migram para os mais diferentes suportes, criando um cinema-mundo ou mídia-mundo" (BENTES, 2007, p. 7). Em complemento à abordagem da autora, que aponta para dois atores decisivos - artistas e mídias - na consolidação de uma cultura de imagens, reconhecemos uma expansão, nos últimos anos, do potencial de agência de usuários e máquinas, que tendem a reconfigurar as dinâmicas em rede.

Munidos de dispositivos integrados à web, em uma economia do compartilhamento, o leitor prosumidor (produtor e consumidor de hipermídia) elabora metáforas visuais e sensórias a partir do remix de informações fugidias e voláteis. Ao mesmo tempo, máquinas, dotadas de mecanismos inteligentes, são capazes de processar bilhões de imagens e dados através de redes neurais e inteligência artificial.

Nesse contexto, o leitor ubíquo é mobilizado pelas estéticas de comunicação e de forma semelhante ao antevisto por Walter Benjamin (apud BENTES, 2007, p. 8), nos leitores que escreviam para os jornais, agora opera equipado de câmeras acopladas a dispositivos com acesso às redes produz imagens que vão ser exibidas em telejornais e plataformas antes engessadas pela cultura de massa. Ao mesmo tempo, um novo território de atuação é desenhado a partir da emergência de plataformas sociais e de novos modelos de negócios que estas propiciam. Narrativas visuais que se fazem valer dos frames em movimento dos GIFs, diálogos construídos a partir do uso de recursos audiovisuais e emojis, criação, edição e indexação de vídeos a partir de dispositivos de baixo custo, são alguns exemplos de práticas de comunicação possibilitadas pelo avanço das tecnologias digitais, e que figuram como boa parte do conteúdo em circulação na internet.

A contrapartida do leitor ubíquo se encontra na do produtor em estado de prontidão que os recursos das redes possibilitam. A exploração estética das redes já não se restringe à atuação de grupos com formações ou atuações específicas. Se, antes, os suportes multimidiáticos exigiam o desenvolvimento de aptidões em um exercício contínuo (a exemplo a criação de HQs) e/ou o aprendizado de softwares específicos para edição, a popularização dos dispositivos ampliou sobremaneira os mecanismos de geração de conteúdos. A partir de aplicativos e sistemas de fácil manuseio, que adotam modelos de interação próximos às dinâmicas presentes nas redes sociais, são exigidas habilidades menos específicas dos usuários. Hoje, 
registrar, editar e criar em imagens, sons ou vídeos é menos dispendioso do que elaborar e digitar argumentos textuais. A exemplo, tem-se a produção de memes no campo da política, quando a junção de textos a imagens ou vídeos curtos cria mensagens repletas de humor e de ruídos. Ao se espalharem e serem reproduzidos, os memes tornaram-se o portal de entrada para que vários eleitores começassem a se engajar em prol de candidatos e causas (BOWLES, 2018). Para Matt Braynar (apud BOWLES), ex-diretor de dados da campanha de Trump, "é quase como um novo meio de comunicação - a imagem, a emoção e a criação.'

Todavia, embora sejam oferecidos diversos mecanismos que facilitem a criação, compartilhamento e acesso à informação, estamos distantes das perspectivas utópicas de uma horizontalização na criação de conhecimento, vislumbradas pelos precursores da web. Para além de um ambiente de distribuição de conteúdo e possibilidades de ruptura de uma estrutura hierárquica, a internet tornou-se um cadinho de ambivalências. Ao mesmo tempo que está aberta à participação, também é um modelo de negócio altamente rentável que não pode ser ignorado. Nossa interação na rede é pautada por tecnologias proprietárias e através da plataforma de empresas que detêm o domínio de uma significativa parcela do conteúdo que circula nos interstícios da web.

A propensão à ação, a que o usuário é convidado, coincide com a complexificação das máquinas que, dotadas de mecanismos de inteligência artificial, processam conteúdos e se comunicam com outras máquinas, sem mediação humana. "Uma particularidade da cultura visual da última década é que boa parte das imagens produzidas são invisíveis a nós humanos." (PAGLEN, 2016, p. 82). O reconhecimento de fisionomias, capacidade atribuída por Polanyi à dimensão tácita do conhecimento, é deveras mais eficiente a partir do uso de sistemas de inteligência artificial regulados por algoritmos. O DeepFace, desenvolvido pelo Facebook em 2014 e implantado em 2015, a partir da criação de abstrações tridimensionais de rostos, e do uso de redes neurais, consegue identificar um indivíduo com precisão de mais de 97\%, uma média comparável à capacidade humana, exceto pelo fato que nossas limitações de memória não permitem recordar do rosto de bilhões de pessoas (PAGLEN, 2016). Sistemas capazes de processar metadados em imagens compartilhadas nas redes sociais, ao ponto de identificar etnia, gênero, classe social, hábitos e preferências de usuários, instituem uma cultura imagética que já não são mais meras representações, mas têm potencial de intervir ativamente nas ações cotidianas. 
Mersch (2015), em sua investigação acerca de um conhecimento não discursivo, propõe um modelo estético de conhecimento que não aponta para um objeto, mas se constrói no "através", de modo a considerar a midialidade e um caráter performativo alçado na práxis (ibid. p. 50-51) 0 conhecimento estético assume-se, então, como um conhecimento reflexivo, um conhecimento excedente que evita uma reconstrução discursiva. Sob tal perspectiva, não cabe à prática de caráter estético buscar um resultado, mas embrenhar-se em uma investigação crítica e contínua. Um conhecimento que não se restringe a um caráter meramente teleológico com um objetivo claro, e que termina em um resultado, mas adquire camadas passíveis de compreensão, em uma busca aberta, como um questionamento contínuo através do meio, em um ceticismo contínuo (ibid. p. 58).

De forma semelhante ao aforismo de Maturana e Varela (2007), que todo fazer é uma forma de conhecer, a performatividade intrínseca ao conhecimento produzido nas redes multimidiáticas ocorre na interação com demais indivíduos e máquinas, atribuindo-lhe um caráter mais coletivo do que individual. Atravessados por feixes de experiência e conteúdo, alternamos entre os papeis de dados e produtores de conhecimento.

O conhecimento tácito, a priori previsto como uma forma de saber que vai além ou está aquém do que podemos dizer, permite uma mudança de ênfase. Polanyi nos fala da identificação do conhecimento tácito com uma interiorização (indwelling) (POLANYI, 2009). A identificação dos dois termos, proximal e distal, contribui no entendimento da maneira como atendemos do primeiro ao segundo. Mas segundo o autor, se considerarmos a integração dos detalhes como uma interiorização, criamos um meio de estarmos cientes aos elementos proximais sobre a entidade que constituem. "Isso traz para nós que não é olhando as coisas, mas habitando nelas, que entendemos o seu significado comum" (POLANYI, 2009, p. 18).

Para manter esse conhecimento é um ato profundamente comprometido com a convicção de que há algo a ser descoberto. É pessoal, no sentido de envolver a personalidade daquele que o detém, e também no sentido de ser, em regra, solitário; mas não há vestígios de autoindulgência... Seu ato de saber exerce um julgamento pessoal ao relacionar evidências com uma realidade externa, um aspecto do qual ele procura apreender. (POLANYI, 2009, p. 18). 
Dentre as diferentes abordagens acerca das dimensões ontológicas e epistemológicas do conhecimento tácito, reconhecemos a afinidade da pesquisa aqui apresentada a uma concepção de conhecimento tácito que, em virtude de sua inefabilidade, depende de outros elementos para que seja compartilhado. "Esse compartilhamento, por ser também tácito, gera novos conteúdos individuais, não totalmente comuns às mentes do grupo que os compartilha, o que ocorre por meio da percepção humana e dos símbolos que a rodeiam" (MIGUEL e SANTAELLA, p. 8). Disso se pode concluir que, embora o conhecimento tácito tenha sempre existido, pois é parte integrante dos processos cognitivos de que o ser humano é dotado, hoje, essa forma de conhecimento enriqueceu-se sobremaneira graças às redes digitais móveis, ao leitor ubíquo que nelas germina e ao agente produtor em estado de prontidão que delas se apropriam.

\section{Nota}

1 É possível encontrar mais informações sobre a palavra do ano, eleita pelo Oxford Dictionarie, em: < https://en.oxforddictionaries.com/word-of-the-year>. Acessado em janeiro de 2018.

\section{Referências}

BEIGUELMAN, Giselle. O livro depois do livro. São Paulo: Editora Peirópolis, 2003.

Disponível em: <http://www.desvirtual.com/thebook/o_livro_depois_do_livro.pdf >. Acesso em: 19 mar. 2018.

BENTES, Ivana. O Devir Estético do Capitalismo Cognitivo. In: XVI Encontro Anual da Associação Nacional de Programas em Pós-Graduação em Comunicação (Compós). Curitiba, 2007. Anais eletrônicos. . . Disponível em: < http://www.compos.org.br/data/ biblioteca_228.pdf>. Acesso em: 19 mar. 2018.

BOWLES, Nellie. The Mainstreaming of Political Memes Online. In.: WELCOME TO THE POST-TEXT FUTURE. The New York Times. 14/02/2018. Disponível em: < https://www. nytimes.com/interactive/2018/02/09/technology/the-rise-of-a-visual-internet.html>. Acesso em: 19 mar. 2018.

DAVEPORT, Thomas H.; PRUSAK, Laurence. Working knowledge: how organizations manage what they know (versão em eBook). Boston : Harvard Business School Press, 1998. HAN, Byung-Chul. Sociedade do cansaço. Petrópolis: Vozes, 2015. 
LATOUR, Bruno. Ciência em ação: como seguir cientistas e engenheiros sociedade afora. São Paulo: Editora UNESP, 1997.

MANJOO, Farhad. State of the Internet. In.: WELCOME TO THE POST-TEXT FUTURE. The New York Times. 14/02/2018. Disponível em: <https:/www.nytimes.com/ interactive/2018/02/09/technology/the-rise-of-a-visual-internet.html>. Acesso em: 19 mar. 2018 .

MATURANA, Humberto R.; VARELA, Francisco J. A árvore do conbecimento: as bases biológicas da compreensão humana. São Paulo: Editora Palas Atena, 2007.

MERSCH, Dieter. Epistemologies of Aesthetic. Zurich: Diaphanes, 2015.

MIGUEL, Lilian; SANTAELLA, Lucia. A relevância da semiótica para o campo da Administração: aplicação à questão do conhecimento tácito. (no prelo).

PAGLEN, Trevor. Invisible Images (Your Pictures Are Looking at You). In.: THE NEW INQUIRY. Publicado em 08 de dezembro de 2016. Disponível em: <https://goo.gl/JSZVsk>. Acesso em: 19 mar. 2018.

POLANYI, Michael. The tacit dimension. Primeira edição de 1966. Chicago and London: The University of Chicago Press, 2009.

SANTAELLA, Lucia. Navegar no ciberespaço: o perfil cognitivo do leitor imersivo. São Paulo: Paulus, 2004.

Paulus, 2013. Comunicação ubiqua: repercussões na cultura e na educação. São Paulo:

A aprendizagem ubíqua na educação aberta. In.: Revista tempos e espaços em educação. Volume 7. N. 14. Setembro/dezembro 2014. Disponível em: <https://seer.ufs.br/ index.php/revtee/article/view/3446>. Acessado em dezembro de 2017.

SOUSANIS, Nick. Desaplanar. Tradução Érico Assis. São Paulo: Veneta, 2017.

VIEIRA. Jorge de Albuquerque. O universo complexo e outros ensaios. Rio de Janeiro : Rizoma editorial, 2015.

VITA, Luís Washington. Introdução à filosofia. São Paulo: Edições Melhoramentos, 1964.

recebido em 10 mar. 2018 / aprovado em 13 mar. 2018

Para referenciar este texto:

POLICARPO, C.; SANTAELLA, L. A estética do conhecimento nas redes digitais. Dialogia, São Paulo, n. 28, p. 29-45, jan./abr. 2018. [DOI: 10.5585/Dialogia.n28.8455] 


\title{
A arte (música) e a educação: encontro eterno, esquecimento perene
}

\author{
Art (Music) and Education: everlasting meeting, perennial oblivion
}

\author{
Catarina Justus Fischer \\ Pós-Doutorada em Educação, UNINOVE-SP. \\ Doutora em História da Ciência, PUC-SP. \\ catarina.fischer@gmail.com
}

Resumo: O presente artigo foi elaborado com a intenção de despertar a atenção do leitor para a importância de se olhar a arte (música) por diversos aspectos e possibilidades, aplicáveis como uma ferramenta auxiliar para a educação. Mediante indícios que foram surgindo ao longo dos séculos, dos quais alguns relacionados neste texto, nota-se que a música é muito mais do que apresenta seu caráter hedonista.

Palavras-chave: Arte. Música. Educação.

\begin{abstract}
The content of this text aims to trigger the attention of the reader to the importance of the art (music) and its significant potentialities, applicable as an auxiliary tool for education. In this article some indications from past centuries substantiate that music is something more than just pleasure and entertainment.
\end{abstract}

Keywords: Art. Music. Education. 
As crianças de hoje serão os adultos de amanhã, e pode-se dizer que serão elas que irão levar adiante o conhecimento. Elas são o futuro, o futuro da humanidade, e o que passarmos para as nossas crianças será o fruto do que elas irão transmitir às suas crianças. $\mathrm{O}$ futuro da humanidade depende das nossas crianças de hoje. Para tanto, algo que parece óbvio, a educação, desempenha o papel fundante deste caminho a percorrer. A arte e a música acompanham e são cúmplices nesta eterna caminhada, do passado remoto até o incerto amanhã.

Sabe-se que para o desenvolvimento de uma aprendizagem e para o crescimento de cada um de nós como seres atuantes, faz-se necessário um processo que envolva minimamente quatro áreas do saber: a do conhecimento, a do afetivoemocional, a de habilidades e a de atitudes, ou valores. (FISCHER, 2014a, p. 116).

Acrescentando às diversas áreas do saber, sem os pressupostos ou interferências dos "dogmas" preestabelecidos dentro das ramificações da árvore do conhecimento, as artes, mais especificamente neste caso a música, deveriam ser consideradas como ferramentas facilitadoras para a educação.

Apesar de não haver conflitos entre a educação, as ciências e as artes, atualmente não se pode afirmar que elas estejam atuando em sincronia ou em conjunto para facilitar ou mesmo para melhorar a forma como se aprende. Por meio das mais diversas pesquisas, busca-se sempre entender melhor de que maneira as artes (música) podem ser utilizadas como uma ferramenta auxiliar no exercício da criatividade, do raciocínio, na persistência e na organização do pensamento dos seres humanos.

Atualmente, neste período que apresenta tantos conflitos, desentendimentos e uma grande disseminação de preconceitos, culpar a ignorância por tal infortunada época é no mínimo pertinente. Chocante, mas não deixa de ser uma verdade. As pessoas, em geral, não gostam de aprender. Não gostam de ler e o conhecimento é por elas relegado e desconsiderado.

Nunca é demais reiterar que aquilo que se propõe não se encaixa facilmente em nenhuma categoria das disciplinas até hoje estudadas (D’AMBROSIO, 2015, p. 312). ${ }^{1}$ De que maneira as artes (música) podem ser incluídas como uma disciplina auxiliar para as diferentes áreas e disciplinas? E como esta área do conhecimento poderia produzir resultados, incentivar o aprendizado e se encaixar na árvore do conhecimento atual?

Como se sabe, estas questões e as artes em si (música) ainda não possuem uma definição ou um nome concreto, mas talvez, em um futuro não muito 
distante, se possa nomeá-la e atribuir uma função a ela. Se não estivermos engessados por uma epistemologia rígida que atualmente circunda a educação e nosso pensamento contemporâneo, talvez se possa encontrar novas formas de despertar a curiosidade, como tantas vezes Paulo Freire tem invocado, e também a vontade de aprender, ler e cada vez mais aprimorar o conhecimento.

Infelizmente, as distorções ideológicas fizeram parte de nossa história e, segundo Cornford (1952), os originais gregos compilados teriam sido transformados de acordo com o interesse dos homens muitos séculos depois de escritos. E isto também se deve, em parte, à falta de interesse dos compiladores, ou falta de compreensão dos conteúdos dos textos.

É provável que tenha sido através da tradição oral, transmitida pelo ato de cantar, que a memória do passado conseguiu de alguma maneira se perpetuar e formar o nosso presente. Mas também, como se pode notar, há múltiplas outras formas em que a música se faz presente na história do desenvolvimento humano.

Há indícios de que, na antiga China de Confúcio, as pessoas mais valorizadas dentre os chineses eram aquelas que apresentavam habilidades em música, poesia, caligrafia, desenho e no manuseio do arco e da flecha. (GARDNER, 1999, p. 1).

$\mathrm{Na}$ cultura da Índia da Antiguidade, a música também fazia parte de seus costumes, mitos e cultos religiosos. Na ideologia musical indiana, a música é valorizada não apenas pelo prazer que proporciona, mas também pela experiência extrassensorial ao proporcionar um vislumbre de uma realidade que está além da realidade dos sentidos humanos. Para os indus, a música é a grande harmonia universal, razão pela qual a música ocupa a mesma importância da religião. (ROWEN, 1979, p. 5, grifo nosso).

No Antigo Testamento, os salmos de David, assim como uma canção dos tempos de Moisés, no Êxodo 15,21 estão preservados e lembram hinos. Espalhadas pelo Antigo e Novo Testamento encontram-se referências aos instrumentos musicais e ao hábito que os povos tinham de cantar hinos e salmos (ROWEN, 1979, p. 16). A poesia hebraica está estritamente associada à música. E, como menciona Zwilling (2013, p. 10), "[...] de fato, todos os salmos possuem um certo caráter musical, que determina o modo como devem ser "salmodiados"'.

Cada vez há mais indícios de que a música tenha sido utilizada como um meio de selecionar, destacar, elevar e educar as pessoas em todas as épocas. Entrelaçada entre o tempo, a memória, a educação, lentamente a música foi estabelecendo paralelos entre as diversas disciplinas. 
Com as ideias de Platão sobre a natureza e as funções da música tal como vieram mais tarde a ser entendidas, tem-se os indícios de que a música exerceu profunda influência na educação (GROUT; PALISCA, 1994, p. 20). Para Platão, a música não era apenas proeminente na vida cotidiana, mas também servia como um veículo auxiliar para o entendimento mais avançado dos estudos em geral (MATHIESEN apud STRUNK, 1998, p. 5).

Faz-se apropriado incluir aqui o ponto de vista de Ubiratan D'Ambrosio (2015, p. 310-312) no texto em que se refere à transculturalidade e transdisciplinaridade, segundo o qual

A atual organização universitária privilegia o conhecimento definido por limitações epistemológicas rígidas, responsável pela organização departamental, que pode se tornar um obstáculo ao intercâmbio de experiências nas variadas formas de conhecimento. ${ }^{2}$

As artes (música) nunca se encaixaram facilmente em nenhuma categoria das disciplinas (GOUK, 1999, p. 4). ${ }^{3}$ Muitas vezes, a música tem sido utilizada como instrumento de manobras políticas para exaltar o civismo e organizar as manifestações das massas em apoio aos líderes dos governos (CONTIER, 1998). ${ }^{4}$ A música sempre consegue mobilizar as massas e sensibilizar a todos os presentes ao mesmo tempo.

Como um fio condutor que interliga as partes separadas como em uma costura, as palavras de Deleuze demonstram como todos os elementos (tempo, memória, ciência, música, educação) estão interligados, assim como sempre foram. Tudo o que se percebe vem a ser importante para o entendimento de um todo. Razão pela qual, talvez, apropriar-se da diversidade do conhecimento seja tão essencial.

Não há nenhum privilégio de uma destas disciplinas em relação a outra. Cada uma delas é criadora. O verdadeiro objeto da ciência é criar funções, o verdadeiro objeto da arte é criar agregados sensíveis e o objeto da filosofia, criar conceitos. (DELEUZE, 2010, p. 158).

Para entender como a música realmente pode ser uma ferramenta auxiliar e facilitadora do aprendizado, Good, Russo e Sullivan (entre muitos), 
pesquisadores da área da psicologia cognitiva, comprovaram, em um estudo, que as crianças submetidas ao ensino de uma língua estrangeira através do canto aprenderam mais rapidamente e com menor dificuldade a língua proposta do que as crianças que foram submetidas ao aprendizado convencional. Suas conclusões neste estudo confirmam a noção empírica de que uma canção facilita a memorização de textos. Aprender cantando, ainda segundo este estudo, pode intrinsicamente motivar o foco de atenção assim como ser uma maneira mais agradável para aprender em todas as idades. (GOOD; RUSSO; SULLIVAN, 2015).

Em especial, o neurologista Oliver Sacks conta o caso de um homem que perdeu sua memória completamente, tendo apenas um minuto de retenção sobre quem ele é, para logo a seguir, perder-se novamente, que nada sabe sobre a sua própria identidade. Quando fica exposto a uma música já conhecida, anterior ao trauma, consegue repetir palavra por palavra da canção, assim como consegue reconhecer a sua esposa enquanto a música é tocada para depois esquecer-se completamente de quem seja a esposa ou ele próprio. (SACKS, 2008).

Platão também acreditava que a música devia ser utilizada como uma ferramenta auxiliar para a memorização e que era de grande utilidade para o ensino das crianças. Em Timeu, os indícios são aparentes quando Crítias, referindo-se ao passado, relembrado através das narrativas orais (PLATÃO, 1972, p. 79-80), menciona que "[...] as crianças 'cantavam' os poemas dos diversos poetas do passado". E no Estado Ideal, Platão refere-se à educação como sendo esta soberana. E diz que para se atingir o ideal por ele descrito, a arte desempenha um valor fundamental. E mais, para ele, a música é extremamente importante, e serve não apenas com propósitos de entretenimento superficial, ou para acalmar as paixões humanas, como também é útil para a construção da personalidade do indivíduo.

Um dos indícios de que mal-entendidos podem ocorrer com a interpretação das palavras encontra-se na Antiguidade, com o mito da caverna de Platão. Na Alegoria da Caverna, entende-se que na parede estão as sombras projetadas e as pessoas que veem essas sombras acreditam estar vendo a realidade (verdade). Quando um indivíduo consegue sair da caverna, ao retornar, não pode explicar o que viu na claridade, sem as sombras, por falta de conhecimento dos nomes de todas as coisas que nunca havia visto antes. Entretanto, em Gleiser (2014), entende-se que esta caverna pode ter muitas paredes, e mais, podem haver diversas 
paredes dentro de outras paredes, assim como as bonecas russas, umas dentro das outras. E um ponto interessante levantado pelo professor de física e de astronomia, diz o seguinte: "Platão sonhara com uma caverna cuja saída levaria à luz da sabedoria perfeita" (GLEISER, 2014, p. 95).

O que ocorre com a música não é diferente. As palavras musicais podem ser entendidas de diversas maneiras distintas. Em Mathiesen (1984, p. 265), a palavra harmonia na música antiga grega pode ser entendida de diversos modos. Em Timeus e em Fedro, de Platão, e na Política e na De Anima, de Aristóteles, a harmonia em seu sentido mais completo significa uma unificação das coisas que se apresentam desordenadas, desiguais ou sem nenhuma relação umas com as outras. Para Mathiesen, duas coisas podem ser notadas: a) o quão menos teóricos sofisticados (e alguns comentadores modernos) começam a pensar sobre as espécies tonais e as oitavas como sinônimos para a harmonia; b) enquanto que a oitava, a proporção, ou os tons são harmonia, o contrário não é verdadeiro, pois a harmonia não é um tom, não é uma oitava e nem uma proporção. E cita Aristides Quintilianus (De musica 1.1, 3, 8, 11-12, 19; 2.4, 6,7, 12, 14,16-17; e 3.6, 9, 12, 22 e 27) e Ptolomeu (Harmonica 3.3-7, 10-11). (cf. LLOYD, 1989, p. 206). ${ }^{5}$

Diversos pensadores do passado consideravam a música como um sistema e não como uma parte consorte da filosofia. ${ }^{6}$ Portanto, devemos ter em mente que, quando estudamos a teoria da música antiga grega, a harmonia não é a harmonia como os músicos a entendem atualmente (MATHIESEN, 1984, p. 266). O mesmo pode ser aplicável aos outros termos musicais ou não musicais.

Deve-se lembrar que, desde que começaram a ser escritos os tratados de música, os tons, os harmônicos, as escalas, e outros mais, sempre foram associados à harmonia. As notas e o que representam também fazem parte deste mesmo grupo harmônico. E, segundo Mathiesen (1984, p. 265), estas interpretações dependiam do grau de erudição do teórico. 0 primeiro interesse dos teóricos antigos era o de associar a harmonia musical às verdades filosóficas ligando proporções básicas, ordem e até algumas escalas e a álgebra, mimeticamente, às características do universo. Isto é, acreditavam que o universo e a natureza poderiam ser compreendidos através da harmonia musical, que, conforme se sabe, os teóricos da Antiguidade chamavam de harmonia das esferas. Mathiesen conclui que a harmonia e o ethos na música grega da Antiguidade estão interligados, assim como abrigam todo o corpo do que ele chama de mousike. Ethos é uma 
palavra originária da Grécia e que tem como significado, entre outros, "caráter moral", e que esta palavra pode ser usada para descrever um conjunto de hábitos ou crenças.

Em Boécio (480-525 A.D.), percebe-se claramente os perigos da diversificação dos sentidos dados às palavras. Pois, em seu tratado De institutione musica, ele define que

Harmônica é uma parte da ciência teórica e prática que lida com a natureza dos harmônicos. E os harmônicos são constituídos de notas e de intervalos dentro de uma certa ordem. As partes dos harmônicos são sete: notas; intervalos; gêneros; escalas; tom; modulação e composição. (cf. FISCHER, 2012, p. 82).

Em nossos dicionários, a definição para a palavra harmonia aparece como: a) conjunto ou sucessão de sons agradáveis ao ouvido; b) ciência da formação e encadeamento de acordes, princípios e normas que as regulam; c) disposição ordenada das partes de um todo, a harmonia do colorido das flores; d) simetria, regularidade, conformidade, coerência; e) concórdia, paz, acordo. (HOUAISS, 1987, p. 431, grifo do autor).

Portanto, observa-se que, com a música especificamente, a harmonia é considerada uma ciência que se refere tanto à física do som quanto aos intervalos sonoros, podendo indicar também a concordância entre vários sons.

Encontram-se também, no livro História da Música Ocidental, os indícios de como as palavras adquirem sentidos diversos quando se lê sobre o sistema tonal grego em que Cleonides (talvez do século II A.D.) enumera a harmonia contendo sete tópicos, em seu compêndio da teoria aristoxeniana, enquanto que o próprio Aristoxeno discute cada um dos tópicos ordenando-os de maneira diferente. (GROUT; PALISCA, 1994, p. 22).

A palavra harmonia, aplicada à música, pode inferir conotações de absoluto cunho religioso, como, ao saltar diversos séculos adiante, no século dezessete, observa-se como pensadores calvinistas desse período referiam-se à harmonia musical:

A harmonia é a ordem que mantém a unidade; pois Deus é autor e mantenedor de toda a ordem, e da unidade maior. E mais, 
Deus é o líder de uma alegria imensurável, portanto aqueles que se regozijam justamente, Dele se aproximam. Por esta razão dizem os rabinos, que o Santo Espírito canta em júbilo. E os filósofos dizem que a alma do homem sábio deve sempre se alegrar; pois sendo Harmonia pura a alegria, esta só poderá ser estimulada e mantida pela Harmonia Musical. (ALSTED apud FISCHER, 2012, p. 61).

Segundo Deleuze (2010, p. 158), a filosofia, a arte e a ciência entram em relações de ressonância mútua e em relações de troca, mas a cada vez por razões intrínsecas. Portanto, entende-se que a filosofia, a arte e a ciência são todas igualmente importantes para se obter o conhecimento de um todo. E mais, para Bergson, segundo Deleuze, a duração do tempo não está atrelada ao presente, passado ou futuro. Portanto, nota-se que, desde sempre, apesar das formulações a respeito do tempo serem sempre adaptadas ao pensamento vigente do determinado período, os tempos coexistem. E estão intrinsecamente atrelados à memória. E pode-se dizer, ainda, segundo a análise de Deleuze (2008) em Bergsonismo, que o passado vem antes do presente porque a memória é a fundação ontológica do ser.

Nosso ser é uma construção, assim como aprendemos sempre, tendo a priori algumas referências. E as referências, musicais ou não, as obtemos através da memória, possibilitadas através de uma consciência inserida de nós mesmos dentro de um tempo. Portanto, entre outros fatores ainda não vistos por nós, o tempo, como o percebemos em nossa condição de ser, é percebido por nós de acordo com a nossa capacidade de reter as experiências e o nosso conhecimento na memória. E é a partir desta nossa condição de ser que percebemos que existimos e que não apenas vivemos estando no mundo, com o mundo (FREIRE, 2012, p. 56). Saímos de nossa condição unidimensional do tempo para aprendermos com o ontem, perceber-nos enquanto no hoje e construirmos um amanhã. E assim como nos diz Paulo Freire (2012, p. 58): “Objetivando-se a si próprio, discernindo, transcendendo, lança-se o homem num domínio que lhe é exclusivo - o da história e o da cultura".

Atualmente, em nossa cultura, a música tornou-se uma instituição poderosa no que se refere à produção cultural, e a linguagem do tonalismo tornou-se um dos mais estruturados sistemas. Valoriza-se a música como entretenimento e, em 
alguns poucos casos, como arte, mas atualmente há um esquecimento da música como um possível meio de transporte dos nossos valores culturais e educativos. (IAZETTA, 1993, p. 12).

Mas mediante os indícios coletados aqui e acolá, nota-se que diversos segmentos do conhecimento já perceberam a importância da música, não apenas como um meio de entretenimento ou de arte, despertando cientistas e pensadores das diversas áreas do conhecimento, que estão voltando-se para a pesquisa do algo mais que está contido dentro da música, e que poderá de alguma maneira ser utilizada para melhorar e facilitar o ensino dentro das escolas, assim como em despertar novamente as pessoas para o prazer de ler e aprender.

Até o momento é a nossa competência cultural (HOFSTEDE, 2002, p. 18) que nos possibilita, através da formação das palavras, a construção de uma linguagem. E é com a linguagem que estabelecemos os nossos limites. Limites estes que poderão ser suplantados mediante o uso da imaginação, viabilizados através do conhecimento.

\section{Notas}

1 Ver interessante artigo de D'Ambrosio, aonde ele coloca que a Academia privilegia o conhecimento apenas que seja definido por limitações epistemológicas rígidas, e responsabiliza as mesmas por se tornarem obstáculos para interdisciplinaridade.

2 Notamos que a dificuldade vai além das propostas pesquisadas, pois sempre que se apresenta alguma inovação em pesquisas, a academia, por ser como é, dificulta e por vezes desanima a continuidade destas pesquisas.

3 Gouk inicia seu capítulo dizendo que entende seu livro como uma resposta às dificuldades impostas pela especialização, assim como pela divisão do conhecimento dentro das ciências humanas e sociais. A seu ver, este ramo do saber provou ser extraordinariamente indefinível para ser utilizado como material para as pesquisas e debates acadêmicos. E isto não se deve à falta de materiais documentais, ou de fontes, mas sim à maneira como foram se organizando as disciplinas acadêmicas.

4 Como, por exemplo, o Canto Orfeônico no Brasil.

5 Em Harmonica, Aristoxenus dedica um grande espaço para tratar sobre explicações e definições das palavras musicais. Entre estas terminologias musicais, encontram-se as palavras tensão, relaxamento, profundidade, altura, afinação, escala, intervalo, entre outras.

6 Notamos que a música no passado, como se sabe, era considerada como parte integrante do Quadrivium. 


\section{Referências}

ALSTED, Johann Heinrich, Encyclopaedia Septem Tomis Distinca: serie Praeceptorum, Regularum, \& Comentariorum Perpetua, 2 vols. Herborn: Herbonae Nassovirum, 1630.

CONTIER, Arnaldo D. Passarinhada do Brasil: canto orfeônico, educação e getulismo. Bauru: Edusc, 1998.

CORNFORD, Francis M. Principium Sapientiae: as origens do pensamento filosófico grego. Lisboa: Fundação Calouste Gulbenkian, 1952.

D’AMBROSIO, Ubiratan. Metáfora de Jano na Educação: Mesmice e Inovação como Faces da Prática Educativa. In: BAPTISTA, Ana Maria Haddad; ROGGERO, Rosemary; MAFRA, MAFRA, Ferreira Jason (Org.). Tempo-Memória: perspectivas em educação. São Paulo: Big Time, 2015. p. 305-326.

DELEUZE, Gilles. Bergsonismo. São Paulo: Editora 34, 2008.

Conversações. São Paulo: Editora 34, 2010.

FISCHER, Catarina Justus. Interdisciplinaridade e a música: reflexões e possibilidades. Revista da Fundarte, ano 14, n. 28, p. 116-135, jul./dez. 2014.

.Johann Heinrich Alsted e a 'árvore dos conhecimentos' no século XVII. 2012.

138 f. Tese (Doutorado em História da Ciência) - Pontifícia Universidade Católica de São Paulo, São Paulo, 2012.

FOSTNER, R. Ancients and moderns. São Paulo: PUC-SP, 2009.

FREIRE, Paulo. Educação como prática da Liberdade. São Paulo: Paz e Terra, 2012.

GARDNER, Howard. Intelligence reframed: multiple intelligences for the 21st Century. New York: Basic Books, 1999.

GLEISER, Marcelo. A ilha do conhecimento: os limites da ciência e a busca por sentido. São Paulo: Record, 2014.

GOOD, Arla J.; RUSSO, Frank A.; SULLIVAN, Jennifer. The efficacy of singing in-foreignlanguage learning. Psychology of Music, v. 43, n. 5, 2015. Disponível em: <http://metatoc. com/journals/326-psychology-of-music>. Acesso em: 13 abr. 2015.

GOUK, Penelope. Music, science and natural magic in the seventeenth-sentury England. New Haven e London: Yale University Press, 1999.

GROUT, Donald; PALISCA, Claude. História da música ocidental. Lisboa: Gradiva, 1994.

HOFSTEDE, Gert Jan. Exploring culture: exercises, stories and synthetic cultures. Maine: Intercultural Press Inc., 2002.

HOUAISS, Antonio. Dicionário Houaiss da língua portuguesa. Rio de Janeiro: Objetiva, 1987.

IAZETTA, Fernando. Música: processo e dinâmica. São Paulo: Annablume, 1993.

LLOYD, Geoffrey Ernest Richard. The Revolutions of Wisdom: studies in the Claims and Practice of Ancient Greek Science. California: University of California Press, 1989. 
MAGNANI, Sérgio. Expressão e comunicação na linguagem da música. Belo Horizonte: Editora UFMG, 1989.

MATHIESEN, Thomas J. Harmonia and Ethos in ancient greek music. JSTOR, The Journal of Musicology, v. 3, n. 3, p. 264-274, Summer 1984.

PLATÃO. Diálogos: O Banquete, Fédon, Sofista, Político. Tradução de José Cavalcante de Souza (O Banquete), Jorge Paleikat e João Cruz Costa (Fédon, Sofista, Político). São Paulo: Abril Cultural, 1972.

ROWEN, Ruth Halle. Music through sources \& documents. New Jersey: Prentice-Hall, 1979.

SACKS, Oliver. Musicophilia: Tales of Music and the Brain. New York: Vintage Books, 2008.

STRUNK, Oliver. Strunk's: source readings in music history. New York: W.W. Norton \& Company, 1998.

ZWILLING, Carin. A música no "Livro dos Salmos". 2013. Monografia - (Bacharelado em Teologia) - Faculdade Teológica Betesda, São Paulo, 2013.

recebido em 31 jan. 2018 / aprovado em 22 fev. 2018

Para referenciar este texto:

FISCHER, C. J. A arte (música) e a educação: encontro eterno, esquecimento perene. Dialogia, São Paulo, n. 28, p. 47-57, jan./abr. 2018. [DOI: 10.5585/Dialogia.n28.8317] 


\title{
Folhetos de cordel no ensino de língua materna: a aula de leitura revisitada
}

\author{
Cordel leaves in maternal language teaching: \\ the revisited reading class
}

\author{
Linduarte Pereira Rodrigues \\ Doutor em Linguística. Professor do Departamento de Letras e Artes \\ e do Programa de Pós-Graduação em Formação de Professores da \\ Universidade Estadual da Paraíba, Campina Grande, PB - Brasil \\ linduartepr@gmail.com
}

Rodrigo Nunes da Silva

Mestre em Formação de Professores pela Universidade Estadual da Paraíba, Campina Grande, PB - Brasil rodryggonunes22@gmail.com

Resumo: O estudo traz uma reflexão sobre métodos e práticas de leitura para aulas de Língua Materna, tendo em vista formar leitores proficientes, levando em consideração as tradições orais de transmissão cultural. Aponta possibilidades de abordagem do discurso pós-moderno a partir do folheto de cordel. Objetiva sugerir um trabalho em turmas de ensino médio, com vistas a desenvolver a proficiência leitora e o aprimoramento de conhecimentos essenciais à contemporaneidade. A proposta situa-se numa perspectiva educacional, perpassando as teorias da análise do discurso (AD) e da linguagem. Para tanto, apoia-se em estudos já realizados por Bakhtin/Voloshinov (2004), Hall (2005), Orlandi (2009), Possenti (2009), Sacristán (2002), entre outros. O propósito foi despertar nos alunos o gosto pela leitura e a funcionalidade de gêneros discursivos diversos na escola e na sociedade, o que em nossa prática foi evidenciado pela leitura do cordel.

Palavras-chave: Leitura. Cordel. Discurso pós-moderno. Educação.

\begin{abstract}
The study brings a reflection on methods and practices of reading for Mother Language classes, aiming to train proficient readers, taking into account the oral traditions of cultural transmission. It points out possibilities of approach of the postmodern discourse from the cordel pamphlet. It aims to suggest a work in high school classes, with a view to developing reading proficiency and improving knowledge essential to contemporaneity. The proposal is based on an educational perspective, spanning theories of discourse analysis (AD) and language. For this, it is based on studies already carried out by Bakhtin/Voloshinov (2004), Hall (2005), Orlandi (2009), Possenti (2009), Sacristán (2002), among others. The purpose was to awaken in students the taste for reading and the functionality of diverse discursive genres in school and in society, which in our practice begins by reading the cordel.
\end{abstract} Keywords: Reading. Cordel. Postmodern discourse. Education. 


\section{Introdução}

A partir da perspectiva da Análise do Discurso de vertente francesa (AD), para compreendermos um texto ou mesmo produzi-lo, enveredamos pelas condições em que se dá a produção desse texto, levando em conta não apenas quem escreve, quando ou onde foi escrito determinado texto, mas também o contexto amplo em que essa produção se dá: as crenças, os valores, os aspectos sociais, políticos, históricos, entre outros, que os sujeitos carregam consigo. O poeta popular é voz de uma memória social, denunciando o modo de ver o mundo de uma região, o que faz do cordel um valioso instrumento de pesquisas linguístico-textuais nas escolas e universidades.

A área da educação tem sido "bombardeada" pela famigerada crise dos sistemas e estruturas fortificadas na modernidade. Vivemos em uma época em que praticamente tudo é questionado, relativizado. As crises e rupturas são características da dita sociedade pós-moderna, mas como isso tem sido discutido em sala de aula? Quando o assunto é o discurso pós-moderno, como o cordel pode contribuir em aulas de língua materna, visando despertar a leitura crítica dos alunos de ensino médio? Com o intuito de responder essas questões, buscamos neste trabalho apresentar algumas possibilidades de atividades para a aula de língua materna (ensino médio), para desenvolver nos alunos a proficiência leitora e o aprimoramento de conhecimentos essenciais à contemporaneidade e que envolvam o discurso pós-moderno. O trabalho justifica-se pela necessidade de estudos sobre a linguagem que envolva o sujeito aluno no mundo pós-moderno nas aulas de leitura, numa interface de análise discursiva e produção de sentidos.

Através de uma pesquisa bibliográfica, buscamos base teórica nas leituras efetuadas em Bakhtin/Voloshinov (2004), sobre os estudos da linguagem; em Hall (2005), sobre a condição do sujeito pós-moderno e identidade cultural; em Orlandi (2009), sobre memória discursiva; em Possenti (2009), sobre questões formuladas pela AD referentes à leitura; em Sacristán (2002), sobre cultura e educação na sociedade contemporânea, entre outros. De início, apresentamos as contribuições que a $\mathrm{AD}$ trouxe para os estudos linguísticos, especificamente para prática de leitura. Veremos o destrinchar do termo discurso, conceitos de ideologia, de memória discursiva, entre outros elementos que fazem o momento da leitura ser entendido como um processo de interlocução entre leitor/texto/autor. Com isso, 
veremos que o sujeito leitor, especificamente o aluno de ensino médio, jamais será passivo, mas um agente que busca sentido nos textos lidos.

Em seguida, traremos uma abordagem sobre o discurso pós-moderno na educação, discutindo a relevância do tema diversidade cultural em sala de aula, para o desenvolvimento de uma cultura de paz, tolerância e respeito pelas diferenças culturais. Logo adiante, discutimos sobre a função social do poeta popular, uma vez que ele atua como instrumento de uma memória coletiva, detentor de informações e relatos sociais produzidos pela sociedade.

A partir da análise do folheto "A pós-modernidade ou um mundo desacunhado", do poeta popular Tiago Marinho (2011), traremos sugestões práticas de como abordar o discurso pós-moderno em sala de aula de língua materna no ensino médio, através de atividades direcionadas que promovam o desenvolvimento de um sujeito leitor que pratica a leitura numa concepção ampla, discursiva, dialógica. Neste cenário, o professor tem importante papel, ao mediar e elaborar atividades que visem à interpretação, os sentidos explícitos e implícitos da situação discursiva apresentada. Além disso, ele pode interagir com os alunos, levando-os a refletir sobre pontos positivos e negativos encontrados na dita sociedade pós-moderna, com o intuito de promover o respeito às diversas manifestações culturais. Pode ainda elaborar atividades com fim de reconhecer, relacionar, identificar e se posicionar sobre o caráter informacional do folheto, para que os alunos compartilhem e dialoguem experiências múltiplas, com vistas a fortalecer valores e práticas sociais. Dessa forma, estará cumprindo o dever de formar cidadãos críticos e reflexivos, oferecendo soluções para melhorar a vida da sociedade em que habita.

\section{Análise do discurso e leitura}

Os estudos referentes à $\mathrm{AD}$ trouxeram enormes contribuições, principalmente quando nos referimos ao modo como o "fazer leitura" tem sido trabalhado em sala de aula. Para Bakhtin; Voloshinov (2004, p. 172), "as palavras são tecidas por uma multidão de fios ideológicos". O signo verbal (entendido como unidade dotado de significado) não pode ter um único sentido: vozes permeiam os signos e deles resultam confrontos, discórdias, atritos sociais e ideológicos. Dessa forma, é fato que quando ocorre uma transformação qualquer na sociedade, essa mudança 
repercute imediatamente na língua e os sujeitos envolvidos, por pertencerem à comunidade, associam nas palavras essas mudanças sociais. Assim, as palavras vão exercer a função de uma memória coletiva, memória social.

A memória também faz parte da produção de um discurso. Ao falar sobre a questão da memória como construção de materialidade discursiva e sua complexidade, Pêcheux (1999, p. 52) diz que "a memória discursiva seria aquilo que, face a um texto que surge como acontecimento a ler, vem os implícitos de que sua leitura necessita”. Orlandi (2009, p. 31) também fala em memória discursiva como "o saber discursivo que torna possível todo dizer e que retorna sob a forma do pré-construído, o já-dito que está na base do dizível, sustentando cada tomada da palavra". Para ela, o termo discurso ultrapassa o nível puramente gramatical, linguístico, ou seja, envolve conhecimentos extralinguísticos. É contextualizado, interativo; é uma forma de atuar, de agir sobre o outro, que trabalha com enunciados concretos, regido pelo dialogismo, que tem efeito polifônico, construindo-se e constituindo-se numa rede interdiscursiva.

A AD tem como norte a interpretação, os sentidos explícitos e implícitos de dada situação discursiva. Para compreendermos leitura como um processo de produção de sentidos é preciso enveredar pelas condições em que se faz essa leitura, o que levará em consideração quem lê, por que lê o texto e seu contexto, quem escreveu e quais foram os motivos para se escrever, que posicionamentos e ideologias estão por trás dos ditos e não ditos. Os discursos carregam aspectos externos que se materializam na língua e produzirão sentidos interpretados pelos sujeitos da situação comunicativa.

Desse modo, compreender um texto ou mesmo produzi-lo, nos faz enveredar pelas condições dessa produção, que levará em conta não apenas quem escreve, quando ou onde foi escrito determinado texto, mas também um contexto amplo em que essa produção se dá: as crenças, os valores, os aspectos sociais, políticos, históricos, entre outros, que os sujeitos carregam consigo.

Para Possenti (2009), há duas vertentes nas quais a AD situa a questão da leitura. A primeira "dedica-se a investigação do dispositivo social de circulação de textos, sem preocupação direta com a questão do sentido" (POSSENTI, 2009, p. 10-11). Nas palavras do autor, na segunda vertente: "interessa especificar em que medida cada fator funciona como uma restrição sobre o discurso seja sobre sua a circulação, seja sobre sua interpretação". Enfatizaremos, em nosso trabalho, a segunda vertente. Assim, estaremos transitando pelos modos de 
significação do discurso, dissecando formas diversas de ler, interpretar e atribuir sentidos aos enunciados.

Possenti (2009, p. 12), ainda se referindo sobre o ato de ler pelo viés da AD, explica que "a leitura não é a leitura de um texto enquanto texto, mas enquanto discurso, isto é, na medida em que é remetido a suas condições, principalmente institucionais, de produção". Só conhecer os aspectos formais de uma língua não garantirá a leitura e compreensão de um texto. Compreender um texto é analisar as condições em que se encontram o autor, o leitor e o próprio texto, com foco na interação entre estes três ingredientes do ato de ler. Conforme apresenta Geraldi (2014, p. 107), "A leitura, por sua vez, é entendida como um processo de interlocução entre leitor/texto/autor." Disso, apreendemos que o sujeito leitor jamais será passivo, mas um "agente que busca significações", que busca sentido nos textos lidos.

\section{Educação, cordel e o discurso pós-moderno}

A literatura de cordel tem se tornado objeto de debates calorosos em eventos acadêmicos. Discussões polêmicas emanam do vasto universo temático dessa forma de expressão popular. O cordel acaba refletindo a vivência cotidiana, tratando desde os problemas atuais até a conservação de narrativas inspiradas no imaginário do povo e proveniente da cultura oral. Assim, o poeta popular acaba desenvolvendo diversas funções, tornando-se material textual de inclusão informacional de massa, de saberes e fazeres institucionalizados.

Em termos atuais, Evaristo (2000, p. 120) diz que "o cordel absorveu algumas tendências da modernidade, entre elas a veiculação de informações", de fatos do cotidiano. Para a autora, "o cordel mantém, enquanto narrativa, algumas características de origem, como a função social educativa, de ensinamento, aconselhamento, e não apenas entretenimento ou fruição individual". Assim, percebemos que as necessidades educacionais e sociocomunicativa do cotidiano exigem para o ambiente escolar a circulação de variados gêneros textuais e o cordel se mostra como instrumento valioso de pesquisas linguístico/textuais.

Bauman (2001) defende que o termo "pós-modernidade" condiz com a temporalidade das coisas e de tudo que correm, ou melhor, "escorrem" como 
água. São fluídos, efêmeros. Não há certezas nem as coisas se mantém, nem se estruturam, não ganham forma, pelo fato de tudo ser muito rápido. Tudo é questionável e está na "mira da verdade", verdade relativizada.

Fala-se em crise do sistema educacional. Os problemas e crises enfrentados no ambiente escolar, na sociedade pós-moderna, tem sido palco de muita discussão, levando o profissional docente a buscar novas maneiras de apresentar os conteúdos exigidos pelo currículo escolar. Faz-se necessário repensar o currículo escolar, rompendo com a ideia de padronização e homogeneização instaurada no contexto da escola. A finalidade dessa reflexão seria a promoção cultural e abertura de espaços para o trabalho com a diversidade, pluralidade e cruzamentos das mais variadas culturas. Assim, concordamos com Sacristán (2002, p. 99), ao afirmar que "cultura é a base de um potente vínculo social que nos aproxima das pessoas com quem compartilhamos as representações do mundo, os traços culturais em geral e os modos de comunicação, formando um genérico nós cultural".

A vida social é regida pelo o que diz o "global", as imagens, estilos, os lugares, a mídia, enfim, os meios de comunicação acabam por criar tendências, influenciando significativamente no modo de viver das pessoas. Individualismo, prazer e consumo são palavras-chave no discurso do sujeito pós-moderno.

Criam-se as "redes sociais". A cultura proporciona esse modo de pensar coletivo. Segundo Sacristán (2002), a vida social é desenvolvida em diferentes âmbitos sociais. Aflora-se o sentimento de pertencimento, o que leva o sujeito pós-moderno a criar redes de proximidades e afastamentos. "A educação deve desempenhar o papel de firmar e estimular o que nos une e de diminuir o que nos distância" (SACRISTÁN, 2002, p. 110).

Trazer esse assunto para a escola é tarefa do docente preocupado em transformar seu ambiente de trabalho para formação de cidadãos responsáveis. A sala de aula de língua materna precisa ser revisitada, com olhar para questões referentes às demandas educacionais da pós-modernidade, com vistas a promover a aprendizagem crítica e reflexiva do alunado. $\mathrm{O}$ aluno como sujeito social, torna-se protagonista de seu discurso a partir de um posicionamento crítico, que o promoverá a tornar-se um cidadão responsável e comprometido com a transformação do lugar em que habita. 


\section{O discurso pós-moderno na aula de leitura: folhetos de cordel, sugestões práticas}

Pretendemos trazer algumas possibilidades de abordagem do discurso pósmoderno em sala de aula a partir do folheto de cordel "A pós-modernidade ou um mundo desacunhado", de Tiago Marinho (2011). Veremos a visão defendida pelo poeta popular, detentor de uma visão coletiva, e como o professor pode dialogar com o alunado de ensino médio a partir de questões significativas para o conviver na contemporaneidade. Para tanto, elegemos a aula de língua materna como ambiente propício para o desenvolvimento de atividades que permitirão o aprimoramento do conhecimento do sujeito escolar.

Durante o processo de ação de um projeto de leitura, podemos realizar diversas atividades de modo que o ato de ler torne-se instrumento de participação, mudança e renovação sociocultural. Dessa forma, o momento da leitura passa a ser significativo e oportuno para que o aluno entre em contato com o diferente, enxergando a pluralidade cultural, os modos de aproximação e vínculos para que seja formado um sujeito capaz de exercer cidadania plena. A partir de um conceito amplo de leitura, pode-se ir além do caráter informacional trazido pelo folheto que se pretende trabalhar.

De início, cabe uma reflexão da capa do folheto. A imagem possui um caráter polissêmico, gerador de múltiplos sentidos. Durante uma atividade de leitura da imagem, o leitor pode criar diferentes efeitos de sentido e, ao mesmo tempo, pode ignorar outros. Isso acontece pelo fato de que cada leitor possui conhecimentos prévios distintos, relacionados através de um processo de referenciação e atualização do discurso pela linguagem.

A imagem da capa reflete uma visão de mundo, identidade e memória. Trata-se de uma antecipação da leitura do folheto, bastante sugestiva, por retratar um cenário típico do discurso pós-moderno. As capas de folhetos de cordéis, tradicionalmente, apresentam-se em xilogravura, arte popular da cultura medieval portuguesa herdada pelo Brasil e que se desenvolveu muito bem em terras nordestinas. Ultimamente, há o desenvolvimento do cordel pedagógico, com a representação de desenhos, fotografias etc., que se propaga com o auxílio das novas tecnologias, especificamente a computação gráfica. Em nosso estudo, evidencia-se o fato de que as imagens de capa trazem consigo uma carga de informação riquíssima para compreensão da mensagem que o poeta quer transmitir. 


\section{A PÓS-MODERNTDADE Ou Um Mundo Desacunhado Autor Tiago Marinho}

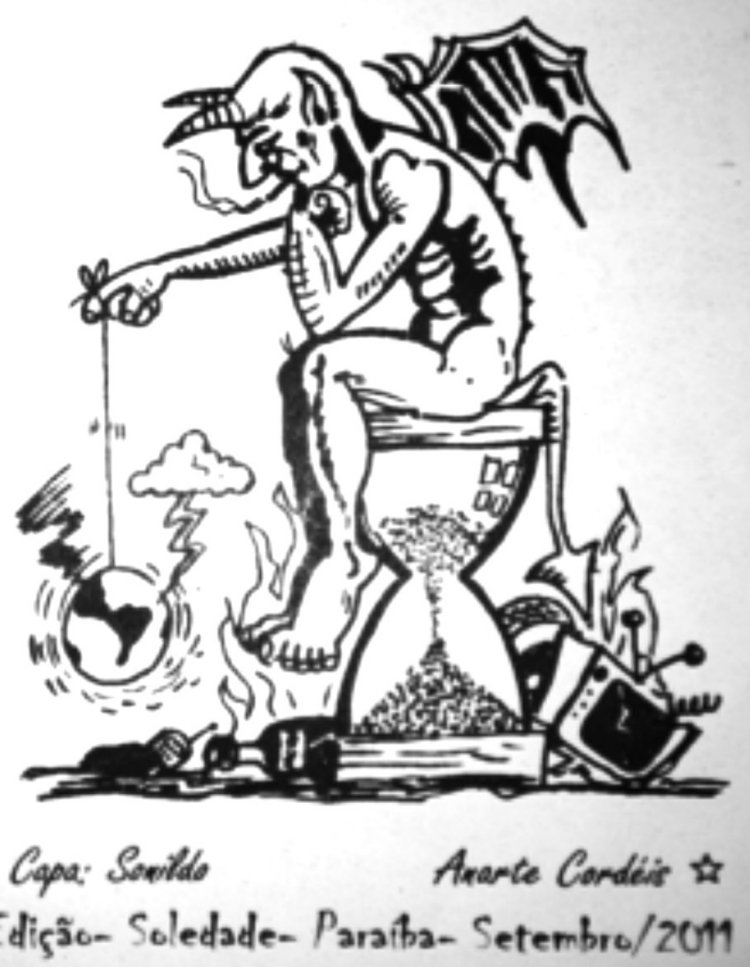

Figura 1: Capa do cordel "A pós-modernidade ou um mundo desacunhado" Fonte: Acervo pessoal

A cena desenhada na capa aponta para um demônio sentado numa ampulheta "brincando" com o planeta Terra como se brinca com um ioiô, um dos mais antigos brinquedos (Terra/ioiô) existentes. Do planeta terra sai fumaça e cai uma tempestade (raios e trovões). Referência a uma ideia de mundo caótico, em crise, "desacunhado". o termo desacunhado, presente no título do folheto, 
mostra o universo vocabular em que o poeta se insere e ao público que se dirige. O termo faz referência àquilo que está em desordem, desalinhado, desmantelado, desarranjado, desconjuntado. A ampulheta atualiza o sentido de um tempo que passa fluidamente, dos medos do ser com relação ao futuro de sua espécie, ideia já cristalizada de um sujeito histórico que sofre com a incerteza da vida terrena (RODRIGUES, 2006; 2011). Há lixo no cenário: um celular, uma garrafa de bebida alcoólica, uma TV. Uma das principais características do pós-modernidade é, sem dúvida, a explosão tecnológica e consequentemente a facilidade de comunicação e disseminação de informações. Contudo, a imagem faz pensar nos pontos negativos desse "avanço tecnológico". Nos dramas, perigos e riscos enfrentados por aqueles que não encontram um sentido para a vida.

O demônio se encontra na mesma posição de uma das mais famosas esculturas do escultor francês Auguste Rodin (O pensador), que retrata um homem em meditação. O demônio, enquanto fuma um cigarro, pensativo, observa atentamente o planeta Terra. Configura-se possuindo dois chifres, asas de morcego e rabo pontiagudo, oferecendo recurso para retomada de memórias cristalizadas a respeito da figura do diabo no discurso religioso cristão: o maioral e originador do mal, que aparece revestido de muitas características da condição humana. É como se a pós-modernidade fosse dirigida por ele e as mudanças, crises, conflitos e atritos gerassem algo não produtivo, desordem, confusão. Percebe-se que atualmente, diante do corre da vida e seus atropelos, do alto índice de violência, da corrupção de valores e princípios, entre outros fatores, o poeta popular se coloca como um neocordelista, denunciando a hipocrisia e os valores anticristãos. Vê-se, assim, que o tema evidenciado pelo cordel é produtivo para o debate no meio escolar, propiciando recurso metodológico para a aula de leitura no ensino médio.

O professor pode levar para sala de aula atividades com o intuito de promover o desenvolvimento do aluno como leitor que pratica a leitura numa concepção ampla, discursiva, dialógica. Ele pode, a partir das experiências dos alunos leitores, aproximar o discurso atualizado pela leitura da capa mediante o incentivo à exploração de suas memórias, exercício de análise linguística de base semântico-cognitiva que se efetiva por meio do recurso da intertextualidade, que permite a relação temática/discursiva dos sentidos postos no plano de fundo das questões pós-modernas exploradas pelas mídias, dentre elas, o folheto de cordel.

Frente ao exercício didático metodológico proposto, cabe à reflexão sobre quem enuncia no cordel e para quem o sujeito do cordel fala, além de ser relevante 
permitir que o alunado busque compreender o motivo que orienta o enunciador se expressar dessa forma e não de outra. O folheto em destaque traz a abertura de um tema significativo e pode ser caminho para um trabalho que gere conhecimentos múltiplos e aperfeiçoamento discursivo, elementos importantes para a formação do jovem leitor. Pode-se ressaltar, ainda, a relação da capa com a poesia do cordel, considerando a compreensão do texto como uma atividade de interação entre o leitor e o autor por intermédio da síntese textual que compõe o gênero capa.

O poeta cordelista reflete nos versos do folheto sua indignação pela destruição dos valores na pós-modernidade. Ele acaba sendo um sujeito informante e líder da opinião pública, "recodificando" para um público popular aquilo que ele capta nos meios de comunicação de massa (GRANGEIRO, 2002). Os versos indicam que o poeta vê com olhos negativos as mudanças ocorridas "nessa tal pósmodernidade", principalmente pela rapidez com que se dá e se faz as coisas, pela superficialidade e mudança de valores, pela incerteza quanto ao futuro e a ilusão do consumismo. Cabe ao professor discutir com seus alunos sobre essa visão do poeta, confrontando com outros pontos de vistas, ressaltando que a sociedade do consumo não é tão somente a de um individualismo egoísta, mas também da preocupação com questões ligadas a identidade e aceitação do outro que possui ponto de vista diferente.

As afirmações negativas do consumismo apresentadas pelo poeta revelam estereótipos e uma ideologia marcada, demonstrada pela característica própria de ver o mundo e interagir com ele. É salutar que o professor alerte os alunos para a conscientização de que o cordelista não deve ser classificado como sujeito preconceituoso, retrógrado e que não aceita as mudanças dos tempos pós-modernos, mas considerar que seus discursos permitem apontar para a reprodução de vozes sociais e, consequentemente, para a manutenção do ato de repugnar "o mundo fluído" pós-moderno (RODRIGUES, 2011).

É evidente a preocupação do poeta quanto aos valores ocidentais serem colocados em desconstrução. O fato é que "as transformações associadas com a pós-modernidade libertaram o indivíduo de seus apoios estáveis nas tradições e nas estruturas" (HALL, 2005, p. 25), ocasionando confrontos e atritos nos sistemas de representação simbólica, seja na esfera da língua, da cultura ou mesmo das diferenças sexuais. Para Hall (2005, p. 22), essa "concepção mutante do sujeito humano" é vista como figura discursiva e diz respeito às transformações que o sujeito humano sofreu até herdar a pós-modernidade. 
O professor da educação básica, visando o desenvolvimento de um trabalho com a leitura que permita a exploração dos sentidos e a própria atualização da produção discursiva, pode interagir com os alunos levando-os a refletir sobre pontos positivos e negativos encontrados na sociedade pós-moderna, com o intuito de promover uma cultura de respeito e paz. Pode ainda elaborar atividades para reconhecer, relacionar, identificar e se posicionar sobre o caráter informacional do folheto de cordel, aspectos essenciais ao exercício da compreensão textual. Como consequência, constrói-se em sala de aula um ambiente de interação através do conhecimento do "outro", e do autoconhecimento, eliminando os possíveis conflitos e desafios levantados, compartilhando e dialogando experiências múltiplas para, assim, desenvolver o respeito pelo diferente. Por isso, o professor deve perseguir um caminho na contramão de toda forma de preconceito e discriminação, trazendo à tona o fortalecimento de valores mediante a prática social da leitura.

\section{Considerações finais}

O cordel é uma das formas mais significativas de expressão cultural da região nordeste. Como observado, levar folhetos de cordel para sala de aula significa propiciar que gêneros textuais que possuem forte ligação com o contexto social do leitor sejam inseridos na escola, fazendo com que os sujeitos sociais encontrem-se representados através dos discursos proferidos por aqueles que se denominam porta vozes do povo.

Em nosso trabalho, buscamos apresentar uma proposta de abordagem do tema da pós-modernidade para um trabalho com a leitura no ensino médio, a partir de folhetos de cordel. Evidenciamos uma possibilidade de trabalho com a leitura multimodal que visou promover o desenvolvimento crítico/reflexivo do alunado, com vistas a atender as demandas educacionais da sociedade contemporânea, principalmente as que se referem ao respeito pelo diferente e o fortalecimento de práticas culturais, propostas advindas do trabalho com a diversidade cultural (RODRIGUES, 2016).

A proposta apresentada visou demonstrar atividades de leitura numa perspectiva discursiva, levando em consideração o sujeito envolvido e as condições em que se dá a produção do texto lido. Vimos que o professor pode tomar o momento 
da leitura como processo de interlocução entre o leitor, o texto e o(s) autor(es). O gosto pela novidade, inovação, o espírito de pesquisador, de instigador, o olhar para o mundo a partir de um ponto de vista outro, são elementos que devem permear a prática pedagógica dos docentes na contemporaneidade, para que a sala de aula possa ser de fato um lócus de interação e desenvolvimento do saber.

Para tanto, o ambiente de sala de aula precisa ser encarado a partir da totalidade de questões referente aos aspectos teóricos e metodológicos da pósmodernidade. O aluno como sujeito social, deve ter acesso aos variados textos/ discursos, trilhar outros caminhos, discutir o mundo que o cerca, para que possa tomar posicionamento e tornar-se protagonista de seu discurso. A partir do momento em que o aluno torna-se sujeito de seu discurso, mostra-se evidente a contribuição de nosso fazer docente para a promoção leitora do alunado, elevando a autoestima e o nível de aprendizagem, além das expectativas de vida no cotidiano das cidades.

\section{Referências}

BAKHTIN, Mikhail (Voloshinov). Marxismo e filosofia da linguagem. São Paulo: Hucitec, 2004.

BAUMAN, Zygmunt. Modernidade líquida. Tradução Carlos Alberto Medeiros. Rio de Janeiro: Jorge Zahar, 2001.

BENEVIDES, Araceli Sobreira. A leitura como prática dialógica. In: ZOZOLI, R. M. D. e OLIVEIRA, M. B. (Org.). Leitura, escrita e ensino. Maceió: EDUFAL, 2008.

EVARISTO, Marcela Cristina. O cordel em sala de aula. In: BRANDÃO, Helena Nagamine. Gêneros do discurso na escola: mito, conto, cordel, discurso político, divulgação cientifica. São Paulo: Cortez, 2000.

GERALDI, J. W. A aula como acontecimento. São Carlos, SP: Pedro e João Editores, 2010. GRANGEIRO, Cláudia Regina Pinheiro. O discurso religioso na literatura de cordel de Juazeiro do Norte. Crato, CE: A Província Edições, 2002.

HALL, Stuart. A identidade cultural na pós-modernidade. Rio de Janeiro: DP\&A, 2005. MARINHO, Tiago. A pós-modernidade ou um mundo desacunbado. Soledade, PB: Cordel Editora Leandro Gomes de Barros, set, 2011.

ORLANDI, Eni Pulcinelli. Discurso e leitura. São Paulo: Cortez, 2012. Análise de discurso: princípios \& procedimentos. 8. ed. Campinas, SP: Pontes, 2009. 
PÊCHEUX, Michel. O papel da memória. In: ACHARD, P. et. al. o papel da memória. Campinas, SP: Pontes, 1999.

POSSENTI, S. Questões para analistas do discurso. São Paulo: Parábola, 2009.

RODRIGUES, Linduarte Pereira. O apocalipse na literatura de cordel: uma abordagem semiótica. João Pessoa: UFPB, 2006. (Dissertação) - Mestrado em Letras - Programa de Pós Graduação em Letras da Universidade Federal da Paraíba - UFPB, João Pessoa, CE. 2006.

Vozes do fim dos tempos: profecias em escrituras midiáticas. João Pessoa:

UFPB, 2011. (Tese) - Doutorado em Linguística e Ensino - Programa de Pós Graduação em Linguística da Universidade Federal da Paraíba - UFPB, João Pessoa, CE.

Folhetos de cordel no ensino de língua materna: aspectos culturais e formação docente. Revista do Gelne, Natal, RN, 2016, p. 140-167.

SACRISTÁN, J. Gimeno. Educar e conviver na cultura global: as exigências da cidadaniaPorto Alegre: Artmed, 2002.

SANTOS, J. F. O que épós-moderno. 5. ed. São Paulo: Brasiliense. 1990. Disponível em: $<$ http://www.cefetsp.br/edu/eso/lourdes/oqueposmodernojair.html>. Acesso em: 01 fev. 2016.

recebido em 27 abr. 2017 / aprovado em 31 jan. 2018

Para referenciar este texto:

RODRIGUES, L. P.; SILVA, R. N. Folhetos de cordel no ensino de língua materna: a aula de leitura revisitada. Dialogia, São Paulo, n. 28, p. 59-71, jan./abr. 2018. [DOI: 10.5585/ Dialogia.n28.7338] 


\title{
Limites e possibilidades do direito à educação pública: contribuições freireanas ao Ensino Musical
}

\author{
Limits and possibilities of the right to public education: \\ freirean contributions to the Musical Teaching
}

\author{
Celso do Prado Ferraz de Carvalho \\ Doutor em Educação. Professor do Programa de Pós-Graduação em \\ Educação da Universidade Nove de Julho, São Paulo, SP - Brasil \\ cpfcarvalho@gmail.com \\ Mauricio Braz de Carvalho \\ Doutorando em Educação - Faculdade de Educação da USP, SP - Brasil \\ Professor de Música na Educação Básica \\ brazmauricio@hotmail.com
}

Resumo: 0 presente artigo se insere nas discussões acerca do retorno do Ensino Musical à educação básica brasileira, em decorrência da Lei no 11.769 sancionada em Agosto de 2008 pelo então presidente Luiz Inácio Lula da Silva. Tendo como foco o universo sociocultural da Escola Pública o texto busca argumentar, que os objetivos político-pedagógicos a serem delineados pela Formação Musical, devem ser constituídos a partir de uma compreensão mais ampla sobre o processo de construção social da escola pública brasileira, da apreensão de suas determinações histórico-sociais e das insuficiências marcantes em sua expansão, bem como de suas aberturas a usos e apropriações voltadas a uma formação efetivamente democrática e emancipadora. Para tais objetivos, recorre-se, dentre outros, ao pensamento educacional de Paulo Freire.

Palavras-chave: Educação Musical. Escola Pública. Paulo Freire. Democratização do Ensino.

\begin{abstract}
The present article belongs to the discussions about the return of the Musical Teaching to the basic education in Brazil, as a result of the Law $n^{\circ} 11.769$ sanctioned in August 2008 by the president at the time Luiz Inácio Lula da Silva. Aimming at the social universe of the Public School, the text defends that the political and pedagogical purposes of the Musical Teaching must be searched over a larger comprehension about the process of the social construction of the brazilian public school: over the apprehension of its historic determinations and of the remarkable precariousness of its expansion, as well as its availability to uses really concerned to an democratic and emancipating education. In order to attain of these objectives, the text makes use, among other authors, of Paulo Freire's pedagogical ideas.
\end{abstract}

Keywords: Musical Teaching. Public School. Paulo Freire. Democratization of the Instruction. 
O presente artigo tem como objeto o retorno do ensino musical obrigatório à educação básica brasileira, tendo em vista as recentes alterações na legislação educacional. Tais alterações têm servido como impulso à realização de um amplo debate sobre as condições de sua efetiva implementação, de sua realização concreta no ambiente escolar. Deste contexto surge o objetivo mais amplo deste artigo: participar, tendo como foco o universo sociocultural da escola pública, do debate sobre os principais desafios a serem enfrentados, bem como sobre os sentidos e objetivos político-pedagógicos a serem perseguidos, nesse percurso de efetivação da educação musical junto às classes populares.

Estamos interessados, sobretudo, em refletir sobre as possíveis contribuições da educação musical no sentido da construção de uma escola pública mais aberta e democrática. Concebendo o trabalho musical em termos sociológicos e culturais mais amplos, buscamos vislumbrá-lo enquanto meio de construção de identidade entre as classes marginalizadas: de denúncia e contraponto aos processos sociais que, historicamente, estigmatizam e deslegitimam os sujeitos e práticas oriundos das periferias, dando-os como inferiores, alienados, ingênuos, atrasados e, sobretudo, perigosos Vislumbramos, nesse sentido, uma prática político-pedagógica que, inserida na dinâmica cultural da escola pública, atue na legitimação simbólica dos saberes e práticas das classes populares, realizando-se criticamente no diálogo e enriquecimento junto aos seus interesses, vozes, leituras de mundo e repertórios culturais.

Assim é que se coloca um dos objetivos específicos desta pesquisa: discutir a iminente implantação do ensino musical tendo como fundamento norteador as diversas, tensas e, muitas vezes, contraditórias, linhas de força que atuaram - e atuam - historicamente na configuração da escola estatal no Brasil. Assim contextualizada, tal discussão cogita as possibilidades de um espaço de formação cultural e artística dos sujeitos que interaja e interfira, de algum modo, na dinâmica deste ambiente, e que o faça indo contra os mecanismos excludentes, seletivos, preconceituosos e autoritários diversamente presentes em nossa história educacional. Enfim, vislumbramos um espaço de reflexão e criação cultural que participe da construção social da escola pública opondose à lógica que se constitui como um processo velado de sua precarização pedagógico-intelectual, de esvaziamento do sentido verdadeiramente público da escola, de deslegitimação cultural das classes populares e seus saberes, de 
justificação dos expedientes de dominação política e de naturalização dos assombrosos índices de desigualdade social.

E é justamente na perspectiva adotada quanto às relações entre as esferas da cultura, da educação e do poder - intimamente imbricadas em nossa história educacional -, bem como quanto às possibilidades de combate e resistência político-cultural, que identificamos no pensamento de Paulo Freire importantes subsídios para as questões que nos propusemos discutir. O pensamento educacional freiriano nos oferece interessantes olhares sobre a Escola Pública, sua relação com a Cultura, seus profundos dilemas atuais e, acima de tudo, suas aberturas a possíveis espaços de transformação e superação. Discutiremos aqui, pois, algumas dessas contribuições: alguns dos conceitos e formulações de Freire que nos auxiliam a pensar sobre a inserção da Formação Musical na escola pública, na perspectiva sociocultural e democratizante já referida.

Em Freire, a ação cultural dialógica refere-se a sujeitos dispostos a unir suas forças em prol da transformação da realidade: o diálogo, na concepção do autor, como a profunda e respeitosa relação entre sujeitos que se encontram no intento de, coletivamente, repronunciar o mundo, dotando-o de novos e mais humanizados sentidos. O princípio pedagógico da dialogicidade, portanto, impõe-se como exigência de toda ação sócio-político-cultural voltada à instauração de novos patamares de sociabilidade entre os homens: de toda ação que se mostre antagônica à situação de exclusão social e de relativa acomodação/alienação política das classes populares. É nesta chave mais ampla - que abarca o universo das relações sociais, culturais, políticas, artísticas e educativas - que ganha corpo a proposta de educação conscientizadora de Freire.

Coloca-se claramente, assim, um dos propósitos centrais de uma pedagogia libertadora: impulsionar a inserção social crítica dos setores tradicionalmente marginalizados. A Pedagogia do Oprimido, nesse sentido, é aquela que atua na contramão das dificuldades tradicionalmente impostas pelas classes dominantes ao processo de desvelamento da realidade por parte das classes dominadas; é aquela pedagogia favorecedora do processo intelectual pelo qual, superando tais entraves, os oprimidos possam apreender as causas estruturais de suas desfavoráveis condições de vida, colocando-se de forma ativa enquanto efetivos sujeitos na reescrita de sua história. Em formulação precisa acerca desta concepção pedagógica enquanto ação cultural transformadora, afirma Freire: "A pedagogia 
do oprimido será sempre [...] a ação profunda através da qual se enfrentará, culturalmente, a cultura da dominação [. . .]." (FREIRE, 2012, p. 46).

Mostra-se, nesse sentido, o importante papel atribuído à educação e à cultura na transformação das marcas injustas e desiguais de nossa sociedade. E, no que diz respeito especificamente à análise da escolarização formal e de suas potencialidades democratizantes (contexto em que se insere este artigo), verifica-se a contribuição das proposições pedagógicas de Paulo Freire. Com efeito, formuladas inicialmente na passagem das décadas de 1950-60 em função dos processos de Educação Popular - sobretudo de alfabetização de adultos -, suas ideias reconhecidamente adquiriram um caráter mais geral, alimentando reflexões aplicáveis ao conjunto do processo educativo.

Nisto, um primeiro e fundamental aspecto: estabelecer a oposição dialogismo versus antidialogismo, na reflexão sobre o ensino regular, significa, antes de tudo, desvendar os fios (tensos e contraditórios) que correlacionam os processos escolares às estruturas macropolíticas que os transcendem. Significa, pois, compreender que as instituições sociais formadoras - tais como a escola e a família - tendem a mimetizar e naturalizar as opressoras e excludentes condições estruturais da sociedade neoliberal, a cujos valores se encontram estreitamente vinculadas.

Temos, assim, um pressuposto basilar da percepção freiriana: toda pedagogia é política e ideologicamente fundamentada, orientando-se - em termos de metodologias, objetivos, destinação de recursos, escolhas curriculares, critérios avaliativos, direcionamento de atenções e prioridades, concepções de reestruturação e reforma etc. - pelos interesses dos grupos que estão no poder em determinado momento histórico, bem como pelos choques, tensões e disputas entre tais interesses e as demandas dos demais grupos sociais. Tal o sentido da declarada politicidade da prática educativa, qualquer que seja o âmbito em que se dê: enquanto ação especificamente humana sobre os homens e sobre o mundo, ela implica, sempre e inevitavelmente, numa tomada de posição: na defesa - ainda que inconsciente por parte de seus agentes - de um determinado ponto-de-vista sobre a realidade.

Em todo o corpo deste capítulo se encontra firmado, ora implícita, ora explicitamente, que toda ação cultural é sempre uma forma sistematizada e deliberada de ação que incide sobre a estrutura 
social, ora no sentido de mantê-la como está ou mais ou menos como está, ora no de transformá-la. [...]

A ação cultural ou está a serviço da dominação - consciente ou inconscientemente por parte de seus agentes - ou está a serviço da libertação dos homens. (FREIRE, 2012, p. 191).

E, em Freire, o reconhecimento desta politicidade pelo educador que se pensa progressista, humanista, assume contornos eticamente radicais de comprometimento e atuação:

Não posso ser professor se não percebo cada vez melhor que, por não poder ser neutra, minha prática exige de mim uma definição. Uma tomada de posição. Decisão. Ruptura. Exige de mim que escolha entre isto e aquilo. Não posso ser professor a favor de quem quer que seja e a favor de não importa o quê. Não posso ser professor a favor simplesmente do Homem ou da Humanidade, frase de uma vaguidade demasiado contrastante com a concretude da prática educativa. Sou professor a favor da decência contra o despudor, a favor da liberdade contra o autoritarismo, da autoridade contra a licenciosidade, da democracia contra a ditadura de direita ou de esquerda. Sou professor a favor da luta constante contra qualquer forma de discriminação, contra a dominação econômica dos indivíduos ou das classes sociais. Sou professor contra a ordem capitalista vigente que inventou esta aberração: a miséria na fartura. Sou professor a favor da esperança que me anima, apesar de tudo. (FREIRE, 1996, p. 102-103).

É assim que uma educação verdadeiramente libertadora não o é apenas num sentido genérico e politicamente neutro; não se resume a metodologias e técnicas modernas, abstratamente voltadas à valorização dos saberes do educando, de sua criatividade, suas aptidões. Na perspectiva freiriana, tal valorização - absolutamente afirmada - se vincula, sempre e necessariamente, ao compromisso ético-político que vincula educador e educando: à valorização das potencialidades a um só tempo criadoras, imaginativas e transformadoras dos sujeitos das classes populares. 
Miguel Arroyo assinala que o mais importante na pedagogia subjacente à acepção freireana [sic] de prática da liberdade e depedagogia do oprimido é o deslocamento da atenção excessivamente focada nos objetos, métodos, conteúdos e instituições em direção ao sujeito. No seu entender, mais do que propor metodologias, Paulo Freire procurou nos reeducar na sensibilidade pedagógica para captar os oprimidos e excluídos como sujeitos de educação, de construção de saberes, conhecimentos, valores e cultura. Sujeitos sociais, culturais, pedagógicos em aprendizado, em formação. (FREITAS; BICCAS, 2009, p. 231, grifo do autor).

Eis, portanto, uma reflexão que consideramos fundamental dentro das ambições deste artigo: termos em conta que a inserção da Formação Musical no universo da escola pública necessariamente implicará, pelos conteúdos, reflexões e abordagens escolhidas, um posicionamento face aos valores culturalmente dominantes. Consequentemente, tal trabalho musical, enquanto instância de formação ética e cultural dos sujeitos, sempre atuará - independentemente de isto ser ou não declaradamente percebido pelos seus veiculadores - no fortalecimento ou no combate à construção de uma mentalidade efetivamente voltada à questão pública; sempre será favorecedor ou (na melhor das hipóteses) omisso quanto à difusão de uma mentalidade centrada em valores mais humanos, solidamente democráticos; uma mentalidade contrária a quaisquer processos de deslegitimação política, exploração econômica desregrada e imposição cultural dos homens sobre os homens; uma mentalidade, enfim, valorizadora da pluralidade entre as diversas culturas, avessa a quaisquer formas de preconceito e exclusão e eticamente comprometida com perspectivas de maior igualdade e justiça social.

Segundo Freire, os procedimentos da educação bancária servem aos interesses dominantes na medida em que, naturalizando a suposta "ignorância" dos educandos e a absoluta "erudição" dos educadores, apresentam o conhecimento enquanto um processo de doação, de entrega. Nesse sentido, são procedimentos calcados na transferência, na mera transmissão acrítica de valores e conhecimentos. Embotam e tolhem, pois, a busca inquieta pelo saber, pelo conhecer, pelo perguntar, pelo criar, pelo entender autônomo e ativo - logo, pelo reinventar e transformar o mundo. Na medida dos interesses opressores, inibem a criatividade e a reflexão autênticas, continuamente reforçando nos homens predisposições à 
passividade, ao ajustamento e à adaptação ao real tal como este se lhes apresenta. Traços, enfim, que definem tal concepção educativa como funcionalmente favorável à perpetuação das condições de opressão:

Esta é uma concepção que, implicando uma prática, somente pode interessar aos opressores, que estarão tão mais em paz, quanto mais adequados estejam os homens ao mundo. E tão mais preocupados, quanto mais questionando o mundo estejam os homens. [...] A concepção e a prática da educação que vimos criticando se instauram como eficientes instrumentos para este fim. Daí que um de seus objetivos fundamentais, mesmo que dele não estejam advertidos muitos dos que a realizam, seja dificultar, em tudo, o pensar autêntico. (FREIRE, 2012, p. 70).

É nesse sentido, pois, que as críticas freirianas ao "bancarismo" se mostram absolutamente significativas ao cogitarmos os possíveis contornos da Formação Musical a ser oferecida às classes populares. Seguindo suas pistas, apreende-se que tal formação não deve estar calcada na irreflexão: na memorização mecânica de conteúdos possuídos e narrados pelo professor, cabendo aos alunos somente o passivo papel de sistematicamente repeti-los e introjetá-los. Não deve, igualmente, oferecer uma leitura da realidade cultural e artística enquanto domesticada - vista como algo parado, a-histórico, sem movimento, um todo já "pronto" e normalizado. Nesse sentido, os conteúdos musicais não devem se apresentar desconectados de uma visão sociocultural mais ampla; de uma perspectiva acerca da totalidade social em que se engendram, totalidade esta cuja compreensão, ademais, muito pode ser favorecida pelas discussões e saberes específicos do universo cultural/musical. Tal formação musical não deve, ainda, bancariamente se dedicar ao tratamento exclusivo de conteúdos, temas e assuntos absolutamente alheios à realidade vivida pelos sujeitos: alheios às experiências, interesses e dificuldades cotidianas dos educandos. Aparece, aqui, outra exigência fundamental ao pensamento pedagógico freiriano, qual seja, a necessária aproximação político-pedagógica entre o mundo da escola e o mundo da vida. Exigência cuja compreensão muito pode agregar às formulações acerca do trabalho musical na rede pública de ensino. 
É assim que, para Paulo Freire, todo processo educativo efetivamente voltado ao alargamento das possibilidades democráticas deveria estar, em grande medida, calcado na problematização do mundo da vida. Pensando a escola pública em seu nível de atuação local, projetam-se novas relações entre a instituição escolar e o caldo cultural da comunidade em que está imersa: a intensa vinculação entre os saberes escolares e os saberes da vida cotidiana. Acredita-se, fundamentalmente, que a fértil interação entre escola e comunidade favoreceria a transformação de ambas, conduzidas a horizontes de maior promoção e emancipação humana.

Entende-se que a real formação dos sujeitos - enquanto a ampliação de suas capacidades de pensar autonomamente, de se colocar de modo criador e reflexivo diante do mundo e dos homens - possui fortíssimo vínculo com a dimensão cultural em seu sentido amplo. Esta formação implica, de partida, que os sujeitos devem poder coparticipar ativamente da própria elaboração do programa educativo: da escolha dos temas, materiais e conteúdos curriculares a serem trabalhados. Nesse sentido, a abertura da escola às vozes e interesses da comunidade proporcionaria que o currículo fosse construído, em cada unidade de ensino, de modo participativo, autônomo e coletivo. O que, na perspectiva freiriana, equivale a dizer: a escola deve ser o lugar onde os sujeitos tenham a oportunidade de criar e de refletir, de problematizar e improvisar, de discutir e inventar, a partir dos materiais, das experiências culturais e das dificuldades sociais cotidianamente vivenciadas.

Na Pedagogia do Oprimido, portanto, valorizam-se os aprendizados, valores simbólicos, práticas culturais e leituras de mundo que se constituem nos diversos âmbitos da vida. Entretanto, frizemos um ponto fundamental: é na contínua problematização e ressignificação destes materiais que reside a função emancipadora do processo educativo. Valorizar a leitura de mundo dos sujeitos não significa simplesmente inserir seus interesses e repertórios culturais, despropositadamente, na programação das aulas; nem, tampouco, uma necessária conversão do educador aos valores e saberes da comunidade em questão, vistos de forma romantizada e louvados enquanto um ideal de pureza a ser seguido. Ao contrário, tal valorização implica em questionar tanto o formato das experiências cotidianas quanto esta própria leitura de mundo que sobre elas se ergue: em desmistificar tanto as determinações da realidade vivida - mormente propagada pela ideologia dominante enquanto natural, inevitável - quanto as percepções, saberes e expressões culturais que acerca dela se constroem, superando-os. 
Chega-se, pois, à função do educador progressista: propor caminhos que aproximem os saberes curriculares fundamentais - suas disciplinas, seus temas e conteúdos, quaisquer que sejam - à realidade concreta dos alunos, proporcionando compreensões mais apuradas sobre o real, novos olhares que os levem a refletir sobre os seus próprios valores, manifestações e saberes socialmente constituídos e, consequentemente, novas possibilidades destes sujeitos se expressarem nas várias instâncias de sua sociabilidade - cultural, política, pedagógica, religiosa, artística.

É nesse sentido que a aproximação entre os processos de escolarização e o mundo que está além dos muros da escola fundamentaria significativas alterações tanto no plano interno quanto no plano externo ao espaço escolar. Escola e comunidade aproximadas e criticamente se influenciando: a comunidade (pais, alunos, professores) se apropriando efetivamente dos processos escolares; a escola debruçada sobre as várias dimensões da vida coletiva, e interferindo nas possibilidades de expressão e participação política, cultural, artística, econômica, social, dos membros da comunidade.

Tal proposta não diz respeito, naturalmente, às causas macropolíticas que explicam a manutenção de padrões de insuficiência no que diz respeito à educação pública em nosso país - às questões estruturais que concorrem, historicamente, para a depreciação dos serviços básicos sempre que estes se destinam às camadas mais empobrecidas da população. Mas aponta ações que, no dia a dia concreto da unidade escolar, em suas (im)possibilidades vividas, fariam significativa diferença. E, no que tange à dimensão do Ensino Musical, sugere um enorme campo de possibilidades: de conteúdos, trocas, discussões e abordagens acerca do universo musical e cultural dos educandos que muito enriqueceriam uma formação escolar radicalmente humanista e emancipadora.

Associa-se, pois, a compreensão dos mecanismos de exclusão socioeducacional à busca por suas possibilidades viáveis de ruptura e combate. Sobretudo, sugere-se que se busque pelas aberturas da escola, pelas brechas, pelos espaços potencialmente transformáveis; que se atente aos seus ainda possíveis sentidos formativos, reiterando a todo tempo tanto os limites quanto as possibilidades e conquistas do direito à educação.

Aproxima-se, nesse ponto, a outra questão central do pensamento freireano: sua postura profundamente esperançosa, a esperança enquanto compromisso histórico. 
[...] este não é um tempo de choro ou fatalismo, embora tenhamos motivo ou vontade de fazê-lo; este é um tempo dramático, desafiador, tempo de briga e de esperança. [. . .] os fatalismos emperram a reflexão. Fatalismo é aceitação passiva, elimina o senso Humano de ser e sentir-se fazedor de História. (FREIRE, apud SAVIANI, 2010, p. 19).

Há, pois, uma crença na vocação ontológica e histórica dos homens de continuamente se humanizarem, continuamente se constituírem enquanto seres criadores e transformadores da cultura e da realidade em que se inserem. Entretanto, um ponto fundamental: esta aposta na mudança, na abertura ao novo, não se mostra enquanto utopia idealista, ingênua; nem, tampouco, como utopia de escritório, restrita ao gabinete, à biblioteca; mostra-se, ao contrário, enquanto utopia político-cultural, utopia em ação.

Trata-se, pois, de uma crença que funciona como força mobilizadora, desencadeadora de energias de resistência. Uma utopia que impulsiona e alimenta a ação, o comprometimento político-pedagógico: a superação das contradições da sociedade é vista como viável, mas somente enquanto decorrência da instauração de uma percepção crítica, a qual desmistifique e denuncie tais contradições como desafio superável, e não como limite instransponível. Daí, novamente, o sentido e o imenso papel do ato educativo. Sobre esta dimensão esperançosa da educação, diz Freire:

[...] a utopia como a unidade inquebrantável entre a denúncia e o anúncio. Denúncia de uma realidade desumanizante e anúncio de uma realidade em que os homens possam ser mais. Anúncio e denúncia não são, porém, palavras vazias, mas compromisso bistórico. (FREIRE, 2012, p. 204, grifo nosso).

Enfatiza-se, assim, a responsabilidade ético-política dos seres humanos na construção de sua ação no mundo, de sua existência. Pois, sendo o mundo atual resultado da ação dos homens, assim também o serão as possíveis superações de suas mazelas.

Esta forma de compreender os movimentos históricos oferece subsídios à interpretação acerca dos insumos sociais historicamente agregados à escola 
brasileira. Ao longo do último século, verificou-se um progressivo e intenso processo de imbricação entre política social e política educacional, a escola passando a assumir funções não diretamente vinculadas à dimensão pedagógica: distribuição de uniforme, merenda, cesta básica, vestuário e leite; assistência médica e odontológica; oferecimento de transporte e salário-educação etc. Trata-se de um movimento complexo, dotado de imensa significação na trama histórica de constituição da escola pública, e que pode ser lido com ênfase em suas contradições.

Não se trata de ignorar os condicionantes macroestruturais mais amplos; nem de menosprezar as linhas de força e poder atuantes ao longo de toda a complexa trajetória da escola brasileira, as quais concorrem, permanentemente, para que a precarização, a insuficiência e o improviso constituam certo padrão distintivo na expansão de seus serviços a parcelas mais largas da população. Trata-se, sim, de uma abordagem que abre a discussão para outros ângulos de visão; que, reconhecendo os usos instrumentais certamente presentes na formulação destas agregações sociais - usos que transformam a escola em ferramenta estrategicamente utilizada pelo Estado no sentido do aliviamento da miséria e de suas potenciais e indesejadas consequências -, procura nelas outros sentidos.

A função social progressivamente assumida pela escola pública é vista, ao menos em parte, como fruto das reivindicações do próprio povo, da própria classe trabalhadora. São elementos que não vieram ao acaso, mas que foram percebidos pelos sujeitos que se encontravam excluídos da escola como uma forma possível de superar aquilo que se apresentava, para muitos, como um gigantesco desafio: ingressar e, mais do que isso, ter condições de permanecer no ambiente escolar. Nessa perspectiva, tais elementos são valorizados quanto aos avanços e ganhos que representam num lento, mas progressivo, movimento de democratização da escola: de sua ocupação pelos novos sujeitos de direitos.

Trata-se, pois, de ponderar que esta contínua agregação de elementos sociais à escola - forma velada e conservadora de gestão da pobreza e de contenção de políticas públicas efetivas (ALGEBAILE, 2009) - também pode ser considerada uma espécie de subversão: foram direitos conquistados, reivindicados, os quais não estavam previstos de antemão e que certamente não foram dados de graça pelos grupos políticos dirigentes. Tal como a progressiva universalização do ensino, não foram conquistados à toa, e sim devido às inúmeras pressões sociais 
das camadas populares no sentido de obterem, também elas, o direito à educação: de conseguirem, na forma como se mostrou possível a cada momento, o direito ao acesso e à permanência na escola, e isso no seio de uma esfera pública historicamente gerenciada por forças pouco dispostas à participação popular ampla, igualitária e verdadeiramente democrática.

Este conjunto de ideias sugeridas pela abordagem educacional freiriana, atento sempre tanto à denúncia quanto ao anúncio, tanto aos obstáculos quanto aos avanços, tanto aos limites quanto às possibilidades da efetiva conquista do direito à educação - e que, neste momento de nossas discussões sobre o Ensino Musical e a Escola Pública, gera inquietações e questionamentos -, possui paralelos com a perspectiva sobre a história social da educação no Brasil defendida por Marcos C. de Freitas e Maurilane de S. Biccas (2009).

Na obra citada, é analisado o processo de expansão da escola brasileira dentre os anos de 1926-1996. Tais autores centram a sua análise, de um lado, no caráter fortemente paradoxal que marca praticamente todos os passos da expansão da escola pública no Brasil: a ampliação e progressiva universalização de um direito que, não obstante, sofreu também progressivos e ininterruptos ataques voltados ao seu empobrecimento pedagógico, ao seu esvaziamento crítico e intelectual, à sua precarização estrutural e à depreciação de seu valor simbólico e reconhecimento social. Nesse sentido, e contextualizando a trajetória da instituição escolar em nossa história republicana, tais insuficiências adquirem um sentido ainda mais amplo: vinculam-se à história de um país desleixado em relação à construção da própria esfera pública como um todo.

Tais colocações não os impedem, todavia, de ler a história da educação no século XX enquanto um contínuo campo de lutas: de disputas, debates e mobilizações intensas voltadas aos temas do alcance e da qualidade da ação estatal sobre a escola em construção. E, quanto aos avanços conquistados, afirmam:

Em relação à escola pública, ainda hoje se reitera frequentemente que ela é fruto exclusivo da 'distribuição' de 'inclusão social' por parte do Estado. Essa 'distribuição' é enganosa. Nem sempre o acesso das pessoas pobres às instituições públicas resultou da ação 'benevolente' do Estado ou das elites financeiras e políticas. Esse acesso muitas vezes foi conquistado por movimentos sociais em momentos nos quais entraram em cena novos atores políticos 
dispostos a invadir territórios institucionais bloqueados. (FREITAS; BICCAS, 2009, p. 22).

Nesse sentido, a ação estatal sobre a escola mostrou-se sempre como um processo em aberto, sujeito aos diferentes interesses e forças sociais em jogo. A perspectiva da análise, portanto, reafirma a História enquanto campo disponível à disputa de sentidos. Não obstante as inúmeras tentativas de uso instrumental da escola enquanto mecanismo de integração social das camadas marginalizadas e de gestão (residual, paliativa) das desigualdades sociais, o livro ressalta, em diversas passagens, uma constante fundamental na trajetória da escola estatal, em síntese, o fato de que a vida social, em toda a sua complexidade, nunca pode ser totalmente direcionada e predeterminada; de que as relações sociais concretas estão sempre abertas às tentativas de ressignificação, de rearranjos; de usos e apropriações muitas vezes distintos dos propósitos inicialmente concebidos pelas forças planejadoras e implementadoras das políticas públicas. Usos estes que, numa perspectiva de longo prazo, podem significar acúmulos históricos fundamentais ao alargamento dos direitos sociais.

Todas as ideias e análises citadas contribuem, pois, para os rumos desta pesquisa. Diante da questão fundamental a que nos propusemos discutir poderia a inserção do trabalho musical interferir na dinâmica cultural da escola pública, contribuindo para oferecer novos rumos à formação por ela oferecida? -, apresentam perspectivas de leitura, de atuação, e geram importantes indagações. Sugerem, sobretudo, que propostas progressistas de transformação e inclusão socioeducacional apreendam os dilemas vividos pela escola com foco em suas tensões e contradições: na profunda apreensão de suas causalidades estruturais, mas, também, em suas possibilidades e aberturas ao aprofundamento do direito à educação efetivamente pública, democrática e de qualidade.

\section{Referências}

ALGEBAILE, Eveline. Escola pública e pobreza no Brasil: a ampliação para menos. Rio de Janeiro: Lamparina; FAPERJ, 2009.

FREIRE, Paulo. Pedagogia da autonomia: saberes necessários à prática educativa. São Paulo: Paz e Terra, 1996. 
Pedagogia do oprimido. Rio de Janeiro: Nova Fronteira, 2012.

FREITAS, Marcos Cezar de; BICCAS, Maurilane de Souza. História social da educação no Brasil. São Paulo: Cortez, 2009.

SAVIANI, Dermeval. Interlocuções pedagógicas: conversa com Paulo Freire e Adriano Nogueira e 30 entrevistas sobre educação. Campinas, SP: Autores Associados, 2010.

recebido em 20 ago. 2017 / aprovado em 2 fev. 2018

Para referenciar este texto:

CARVALHO, C. P. F.; CARVALHO, M. B. Limites e possibilidades do direito à educação pública: contribuições freireanas ao Ensino Musical. Dialogia, São Paulo, n. 28, p. 73-86, jan./abr. 2018. [DOI: 10.5585/Dialogia.n28.7715] 
ARTIGOS

/ ARTICLES 


\title{
Uma análise textual dos discursos empregados no gênero redação do enem
}

\author{
A textual analysis about the used discourses in \\ the textual genre wording of enem
}

\author{
Marilúcia dos Santos Domingos Striquer \\ Doutora em Estudos da Linguagem. Professora da Universidade \\ Estadual do Norte do Paraná (UENP) e do Mestrado Profissional \\ em Letras - PROFLETRAS/UENP, Jacarezinho, PR - Brasil \\ marilucia@uenp.edu.br
}

\begin{abstract}
Resumo: Apoiados em uma abordagem em que texto, discurso e gênero são pensados de forma articulada, analisaremos textos que configuram o gênero textual redação do ENEM, produzidos por alunos do último ano do ensino médio, atendidos por um projeto PIBID. A intenção é a de identificar o que os alunos já sabem sobre a organização textual de seus discursos e o que precisa ser aprimorado ou desenvolvido. O aporte teórico-metodológico se constitui dos preceitos da linguística textual e da análise textual dos discursos. Os resultados demonstram as deficiências que os alunos têm no emprego dos elementos que formam os aspectos globais e dos mais pontuais do gênero, os quais, portanto, devem ser tomados, pela equipe do projeto, como conteúdos específicos.
\end{abstract}

Palavras-chave: Análise textual dos discursos. Textualidade. Gênero textual. Redação do ENEM.

\begin{abstract}
Based on an approach which text, speech and genre are thought in articulated way, texts will analysed that configure the textual genre wording of ENEM, produced by students taking the last grade of high school, served by a PIBID project. The intention is to identify what the students have studied about textual organization and its discourses and what it is necessary to be improved and developed. The theoretical-methodological contribution is made up of the precepts about Textual Linguistics and Textual analysis of discourse .The results have shown the difficulties of the students have in the use of elements that form the global aspects and of the most exact ones of the genre, which, therefore, should be taken by the project team as specific contents.
\end{abstract}

Keywords: Textual analysis of discourses. Textuality. Textual genre. Wording of ENEM. 


\section{Introdução}

Ao considerar a definição de Adam (2011) de que a linguística textual é um "subdomínio da área mais ampla da análise das práticas discursivas, postulando, ao mesmo tempo, uma separação e uma complementaridade" (p. 14), interessamo-nos em investigar a produção textual de alunos do ensino médio. Apoiando-nos, assim, em uma abordagem em que texto, discurso e gênero são pensados de forma articulada, norteados pelos estudos de Marcuschi (2008), Antunes (2010) e Adam (2011).

Sempre preocupados com o desenvolvimento das capacidades de linguagem dos alunos da educação básica, na coordenação de projetos de ensino, extensão e pesquisa, projetos que atuam diretamente na interação entre universidade e escola, vimos nos estudos de Marcuschi (2008), originários dos preceitos de Jean-Michel Adam, a importância de considerarmos um condicionamento mútuo entre texto e discurso ao analisarmos os textos produzidos pelos alunos atendidos por nossos projetos, a fim de que que tenhamos condições de compreender o que os alunos já sabem na organização textual de seus discursos e o que, no efetivo trabalho dos projetos, é preciso aprimorar ou levar a conhecimento dos alunos.

Assim, nosso corpus é formado por textos concretos, produzidos por 26 alunos do último ano do ensino médio, de uma escola da rede pública de ensino do estado do Paraná, atendida, em 2017, pelo projeto de ensino Letras/Português vinculado ao Programa Institucional de Bolsa de Iniciação à Docência (PIBID). Sobre os referidos textos, analisamos os elementos que formam a textualidade, sobretudo, como posto, com a finalidade de conhecer o que os alunos já sabem, especificamente, para a produção do gênero redação do Exame Nacional do Ensino Médio (ENEM), e aquilo que precisa ser tomado como objeto de ensino e aprendizagem pelo projeto, a fim de que os discentes possam de forma adequada participar da referida prática social.

\section{A proposta teórico-metodológica}

Em definição teórico-metodológica para a análise textual dos discursos, Adam (2011) afirma que "a linguística textual é, [...], uma teoria da produção 
co(n)textual de sentido, que deve fundar-se na análise de textos concretos. É esse procedimento que nos propomos desenvolver e designar como análise textual dos discursos" (p. 23, grifo do autor). Nessa perspectiva, defende o autor que texto e discurso não podem ser vistos de forma dissociada, e que parte integrante dos sentidos de um texto são os elementos que formam o seu contexto. Por sua vez, o contexto não pode ser visto apenas como formado por elementos que dão condições para a interpretação global de um enunciado, nem tampouco apenas para reconhecer elementos que fazem referência ao que está fora do texto. De acordo com Adam (2011), para que o leitor (ou o analista) tenha acesso ao contexto é preciso recorrer à memória discursiva, a qual é apresentada por Adam (2011) como um "conjunto dos saberes conscientemente partilhados pelos interlocutores" (p. 57), saberes formados pelos conhecimentos enciclopédicos, pelos pré-construídos culturais, entre outros aspectos que formam a memória discursiva dos interlocutores. Logo, é a memória discursiva que permite a interação entre autor e leitor por meio do texto.

Diante desses conceitos, Marcuschi (2008) defende que discurso é o "objeto de dizer" e está no plano da enunciação, e o texto é o "objeto de figura" (p. 81-82) e está no plano da esquematização, da configuração concreta, "entre ambos, o gênero é aquele que condiciona a atividade enunciativa" (p. 82). Logo, um indivíduo ao participar de uma situação comunicativa, ou esfera social como denomina Bakhtin (2003), a partir de uma intenção comunicativa, tem um objeto de dizer, isto é, elabora seu discurso e, então, elege um gênero, a fim de dizer o que quer dizer, considerando a situação imediata de comunicação, seu papel social dentro da interação em questão, quem é seu interlocutor, o objetivo da interação, entre outros fatores (BAKHTIN, 2003). Tal gênero se concretiza em um objeto material e empírico, um texto.

De acordo com Marcuschi (2008), nesta perspectiva, o gênero

É uma espécie de condicionador de atividades discursivas esquematizantes que resultam em escolhas dentro de uma prática que nos levaria a pensar em esquematizações resultantes. Assim, muitas decisões de textualização (configuração textual com suas estruturas, ordenamento paragráfico, etc.) devem-se à escolha do gênero. Deste modo, o gênero inscreve também formas textuais que se manifestam no artefato linguístico. (p. 85-86). 
Essa definição pode ser exemplificada da seguinte forma: para que os alunos atendidos pelo PIBID participem do ENEM, produzindo o gênero redação do ENEM de forma adequada, a equipe do projeto toma como objetos de ensino e aprendizagem: as característica da situação comunicativa, o que é o ENEM, o que obter um bom resultado no exame implica, quais os programas oferecidos pelo governo para aqueles que alcançam boas notas no exame, quais os conteúdos cobrados nas provas objetivas, quanto tempo pode ser calculado para a escrita da redação, quais competências são avaliadas na prova de redação, quais os temas possíveis, quais as exigências para a estruturação textual da redação, quem são as pessoas que corrigem a redação. Conhecidos todos esses aspectos que configuram a situação comunicativa específica, o indivíduo tem então o que dizer, assim, tem consciência de que o gênero a ser escolhido é a redação, na denominação do ENEM, um texto dissertativo/argumentativo, e para produzir a redação é preciso seguir uma estrutura relativamente estável (BAKHTIN, 2003), com o emprego de elementos discursivos e linguísticodiscursivos que organizam o texto, os quais também são objetos de ensino e aprendizagem na proposta de trabalho do PIBID.

Nessa relação entre discurso, texto e gênero, afirma Marcuschi (2008) que não é possível "dividir os aspectos da textualidade de forma tão estanque e categórica” (p. 93), separando aquilo que forma contexto e o que forma o contexto, uma vez que o texto não é um fenômeno virtual, é uma realidade, uma realização linguística, um evento comunicativo. Em decorrência os critérios da textualização são "muito mais critérios de acesso à construção de sentido do que princípios de boa formação textual" (p. 97).

E é a partir dessas concepções que analisamos os aspectos da textualidade que constituem nosso corpus, tendo como aporte metodológico a proposta de Antunes (2010) apresentada na obra "Análise de textos: fundamentos e práticas", visto que o objetivo da autora é "trazer [na referida obra] uma espécie de reforço à prática da análise de textos, privilegiando, é claro, aspectos da sua textualidade" (p. 13). Para tanto, de um modo geral, a proposta consiste em analisar os aspectos globais e os aspectos mais pontuais que contribuem para a construção dos sentidos de um texto.

Os aspectos globais envolvem tudo aquilo que "confere 'centralidade' e 'unidade semântico-pragmática'" a um texto (ANTUNES, 2010, p. 23, grifo nosso), assim, em uma análise, o foco centra-se no eixo da coerência textual, 
englobando: (1) ${ }^{1} \mathrm{o}$ universo de referência para o qual o texto se remete; (2) a unidade semântica; (3) a progressão do tema; (4) o propósito comunicativo; (5) os esquemas de composição: tipos e gêneros; (6) a relevância informativa; (7) as relações com outros textos.

Já quando o foco de análise centra-se nos aspectos mais pontuais da construção do texto, os objetos são: (A) a coesão e a coerência; (B) os tipos de nexos textuais; (C) a repetição de palavras; (D) a paráfrase; (E) o paralelismo; (F) a substituição de unidades do léxico; (G) a substituição pronominal; (H) a associação semântica entre palavras; (I) os conectores; entre muitos outros aspectos uma vez que, segundo Antunes (2010, p. 58), "é quase impossível enumerar exaustivamente o que podemos analisar nos textos. Uns podem oferecer uma gama maior de elementos, outros, menos, na dependência de uma série de fatores, que, como sabemos, são determinantes para sua composição".

\section{Contextualizando a atividade}

A equipe do projeto $\mathrm{PIBID}^{2}$, para início do planejamento do trabalho em sala de aula, como primeira atividade do ano letivo de 2017, solicitou a produção de um texto dissertativo-argumentativo aos 110 alunos atendidos pelo projeto, de 4 turmas de 3 diferentes escolas da rede pública de ensino localizadas em 2 cidades do norte velho do estado do Paraná. O objetivo da atividade foi o de que a partir das análises dos textos produzidos pelos alunos, os conteúdos específicos fossem definidos, a fim de que só então as sequências didáticas para o ensino e aprendizagem do gênero redação do ENEM pudessem ser elaboradas e implementadas em sala de aula. Neste trabalho, apresentamos as análises realizadas sobre 26 textos produzidos por alunos de uma das 4 turmas.

A atividade teve início com a explicação detalhada pela equipe do PIBID do trabalho a ser realizado em 2017 com os alunos, entre outros gêneros a serem trabalhados a proposta era o de auxiliar os discentes no aprimoramento da produção do gênero discursivo/textual redação do ENEM. Para tanto, a equipe precisava conhecer o que os alunos já sabiam e o que não sabiam a respeito do gênero. Assim, foi oferecido aos alunos a instrução a seguir: 


\section{Proposta de redação}

Redija um texto dissertativo-argumentativo sobre o tema proposto abaixo:

Imagens, discursos e representações sociais presentes na mídia televisiva e na web podem ser incorporadas por adolescentes ao ponto de influenciar comportamentos e a formação para a vida adulta.

Sem mais nenhum comando de produção, os 26 alunos tiveram um tempo cronometrado de 60 minutos para a produção do texto.

Tomando como norte a sugestão de encaminhamento para análise de textos de Antunes (2010), primeiramente, ressaltamos que o gênero dissertativoargumentativo é o solicitado pelo ENEM na prova de redação. Sendo um texto em que o aluno deve desenvolver para o tema um ponto de vista, argumentar sobre ele e ainda elaborar uma proposta de intervenção para o problema em discussão no referido tema. O tema é sempre uma questão ou situação social controversa para a sociedade.

\section{Os aspectos globais}

O que destacamos primeiramente é o fato de que o universo de referência (1) do qual a redação do ENEM participa remete às propriedades de um mundo real, estando, assim, o gênero inserido no campo social-discursivo escolar/ acadêmico, visto que a redação é uma exigência do ENEM, que é uma das portas de acesso às universidades e aos programas de bolsa do governo federal, e por isso objeto de ensino na disciplina de língua portuguesa nos anos que formam o ensino médio, principalmente, no último ano.

A partir dessa definição, recorremos ao quadro de agrupamento de gêneros sugerido por Dolz, Noverraz e Schneuwly (2004), por entendermos que o princípio é considerar texto, discurso e gênero de forma não estanque (conforme ADAM, 2011). Assim ao observarmos como se configura o domínio social de comunicação do gênero propriamente dito, estamos reputando o princípio em referência. Logo, de acordo com agrupamento, o domínio social de comunicação da redação do ENEM é: a "discussão de problemas sociais controversos" (p. 121) esse é o discurso, objeto de dizer (MARCUSCHI, 2008) a ser organizado pelo autor do texto. Contudo, 
conforme Bakhtin e Volochinov (2014), "qualquer que seja o aspecto da expressão-enunciação considerado, ele será determinado pelas condições reais da enunciação em questão, isto é, antes de tudo pela situação social mais imediata" (p. 116, grifo do autor), nesse sentido, ao levarmos em conta o que é a prática social do ENEM, o propósito comunicativo (4) da redação não seria apenas discutir problemas sociais controversos instituídos no tema oferecido pelo exame mas também o propósito do autor da redação deve ser o de produzir um bom texto, seguindo o que é estabelecido pelo exame, a fim de conseguir uma boa nota e, então, ingressar em uma universidade pública ou conseguir bolsas concedidas pelo governo para estudar em uma instituição da rede particular de ensino superior. A redação do ENEM é uma prova avaliativa, conforme expõe a Cartilha do participante: redação do ENEM 2016 (BRASÍLIA, 2016).

A prova de redação exigirá de você a produção de um texto em prosa, do tipo dissertativo-argumentativo, sobre um tema de ordem social, científica, cultural ou política. Os aspectos a serem avaliados relacionam-se às competências que devem ter sido desenvolvidas durante os anos de escolaridade. Nessa redação, você deverá defender uma tese - uma opinião a respeito do tema proposto -, apoiada em argumentos consistentes, estruturados com coerência e coesão, formando uma unidade textual. Seu texto deverá ser redigido de acordo com a modalidade escrita formal da Língua Portuguesa. Por fim, você deverá elaborar uma proposta de intervenção social para o problema apresentado no desenvolvimento do texto que respeite os direitos humanos. (p. 7, grifo do autor).

Portanto, o autor do texto deve considerar na construção da textualidade da redação todos os elementos que serão avaliados pelos corretores, pois o esquema de composição (5) é dado como algo obrigatório ao referido objeto de figura (MARCUSCHI, 2008) exigido pelo ENEM. Contudo, apesar de todos os 26 textos se relacionarem ao universo de referência (1), que caracteriza o gênero, abordando aspectos do mundo real nas redações, como por exemplo, a existência da internet, a televisão, o jogo da baleia azul, a inspiração que os 
jovens adquirem em filmes, novelas, poucos textos apresentam uma discussão do problema indicado no tema, com um discurso organizado a partir da defesa de uma tese que deve apoiar-se em argumentos consistentes, e principalmente apresentando proposta de intervenção, conforme prescreve a cartilha (BRASÍliA, 2016). Dos 26 textos, 7 deles fogem totalmente do tema proposto. Dos 19 restantes, 3 são formados apenas pela exposição de ponto de vista, sem construção de argumentos e proposta de intervenção, o que pode ser reflexo de uma limitação de conhecimento de mundo instituído na memória discursiva do autor (ADAM, 2011) e da falta de adequação necessário do conteúdo à situação comunicativa (BAKHTIN, 2003; MARCUSCHI, 2008). Textos, portanto, que não se estabelecem como materialização do gênero discursivo/textual dissertativoargumentativo. Exemplo:

Texto $1^{3}$ : Redação com a apresentação apenas do ponto de vista do autor Sim, através de imagens, discurso e representações sociais podemos aprender, e sermos influênciados a mudança de comportamento e de mente.

Nos influência na formação da vida adulta porque através dos diversos temas, diversas variações podemos aprender sobre a faculdade, cursos, trabalho assim nos formando pra vida adulta. ${ }^{4}$

O texto 1 , com extensão de 7 linhas, responde ao comando de produção como se o comando fosse uma pergunta; fala sobre influência, mas não promove uma discussão de forma a direcionar a influência gerada pela internet ou pela TV, como posto no enunciado de instrução, sobre o qual, principalmente, o texto 1 é quase que apenas uma paráfrase.

Dentro do conjunto de 16 textos (desconsiderando os 4 que figuram ao tema e 3 que não são dissertativos-argumentativos), 10 apresentam apenas tese e argumentos, sem proposta alguma de intervenção ou de uma conclusão simples. Por esse motivo, também não se caracterizam como dissertativos-argumentativos no plano estrutural imposto pelo ENEM. Bem como, nesses 10 textos os argumentos são todos formados pelo senso comum, não apresentando consistência e estruturação de ideias. Exemplo: 
Texto 2: Redação com apenas a apresentação de ponto de vista e argumentos

Os adolescentes são muito influênciados, por exemplo, o jogo da Baleia Azul que viralizou neste ano, muitos adolescentes que entraram nesse jogo foram influenciados e, até mesmo, obrigados a jogar por medo, os curadores, que são os "donos" do jogo, adicionam os adolescentes no facebook e ameaçam seus familiares, fazendo assim com que se sintam obrigados à participar, sem saber que esse jogo vai levá-los à morte. A mídia, as novelas e as séries, influênciam também, por que os adolescentes acham que tudo que foi passado a eles está certo, sem se informarem de que tudo pode estar absolutamente errado, eles saem fazendo o que viram, e assim acabam até infringindo leis.

O ponto de vista apresentado pelo autor no texto 2 é superficial: os "adolescentes são muito influenciados" e para defendê-lo o produtor apresenta argumentos que fazem referência a um jogo da web e a informação de que muitos adolescentes foram influenciados pelo jogo, mas a afirmação é de que os adolescentes participaram do jogo porque foram ameaçados. Há quase que em uma contradição de posicionamento, uma vez que se jogaram por influência, não poderia ser por ameaça. O texto 2 expõem também que a mídia, as novelas e as séries são influenciadoras dos comportamentos dos adolescentes, porém sem explicativas de quais assuntos ou comportamentos são mostrados nessas mídias para que sejam considerados certos ou errados. Ainda é possível verificar a construção de uma verdade absoluta, como se todos os adolescentes tivessem a mesma opinião a respeito do que assistem, o que vai de encontro a proposta do gênero e ao conceito defendido por Bakhtin (2003) e por Marcuschi (2008) de que as escolhas de textualização estão diretamente ligadas à escolha do gênero.

Portanto, dos 26 textos, apenas 6 se adequam na estrutura do gênero dissertativo-argumentativo, mas ainda assim de forma precária, tangenciando o tema, elaborando de forma pouco consistente os argumentos e a proposta de intervenção. Nesse sentido, compreendemos que os textos são constituídos de tentativas de discutir o problema inserido pelo tema (MARCUSCHI, 2008), não de discussão propriamente dita. Exemplo: 
Texto 3: Redação com a apresentação da estrutura dissertativa-argumentativa As representações sociais presentes na midia influência os adolescentes, pois a televisão influência na opinião das pessoas, fazendo dessa forma o povo não ter uma opinião própria, e sim, uma opinião relativas as representações da web, penso que a mídia deveria passar as informações, mas não passar a opinião deles, porque relativamente isso influencia as opiniões populares.

Sendo assim, a população escolhe "soluções" influenciados pela mídia, mas nem sempre a mídia passa opiniões verdadeiras, causando uma má formação para a vida adulta, pois seriam as consequências da adolescência com opiniões da mídia, e sem opinião própria, causaria um futuro desproporcional na sociedade.

Dessa forma, penso que devemos se informar bem, antes de tirar a opinião sobre o assunto, para não fazermos má escolhas e estragar de alguma forma o futuro.

Uma das cinco competências apontadas pela Cartilha como instrumento avaliador pelos corretores da redação, a competência 2, diz respeito ao autor do texto demonstrar compreender a proposta de redação e aplicar conceitos de áreas de conhecimento para desenvolver o tema, assim como pode ser visualizado no texto 3, nenhum das 6 textos dissertativos-argumentativos produzidos pelos alunos faz menção a conceitos oriundos de outras áreas do conhecimento. Há apenas construções de ideias retiradas do sendo comum. Em decorrência, não há também o cumprimento do prescrito na competência 3, que avalia se o autor tem habilidade para selecionar, relacionar, organizar e interpretar informações, fatos, opiniões e argumentos em defesa de um ponto de vista. Os textos apresentam esses fatores, mas desorganizados e limitados, com sérios problemas de progressão textual (ANTUNES, 2010).

Não diferente é a proposta de intervenção, nenhum dos 6 textos desrespeita os direitos humanos, determinação da competência 5, contudo as propostas não têm rijeza: uma delas em nada se relaciona ao tema, e as outras 5 são vagas e relacionadas apenas ao assunto de forma direta, como pode ser visualizado no texto 3, reiterada aqui: "Dessa forma, penso que devemos se informar bem, antes de tirar a opinião sobre o assunto, para não fazermos má escolhas e estragar de alguma forma o futuro". E em outro exemplo, a proposta do texto 4: "Não viva a sua vida pelos outros, mas sim vivendo a sua vida escolhendo o que você quer. Converse com seus pais, ou se preferir amigos, pois a tv e a internet não irá te ajudar 
a tomar suas próprias decisões". As referidas tentativas de construção de propostas de intervenção revelam que os alunos conhecem a estrutura determinada pelo ENEM, porém os discentes não sabem como construir a referida proposta.

O exemplo retirado do texto 4, supracitado, demonstra também que os alunos não conhecem como se constitui a prática social do ENEM (BAKHTIN, 2003), as características específicas dessa situação comunicativa, a qual determina o discurso a ser proferido pelo participante (MARCUSCHI, 2008), uma vez que alguns alunos "conversam" em seus textos com seus destinatários como se estes fossem adolescentes assim como são os alunos produtores de nosso corpus. Recorrendo a Antunes (2010), o outro elemento que forma (1) o universo de referência de um texto é o destinatário previsto pelo autor, no momento da construção da textualidade. Sendo os corretores das redações do ENEM uma banca formada por dois professores especialistas na área de língua portuguesa, com no mínimo dois anos de experiência em docência ${ }^{5}$, os participantes do ENEM devem dirigir seus textos a esses destinatários. A informação sobre quem são os avaliadores está disponível da Cartilha (BRASÍLIA, 2016, p. 8): “Quem vai avaliar a redação? O texto produzido por você será avaliado por, pelo menos, dois professores, de forma independente, sem que um conheça a nota atribuída pelo outro". Logo, os alunos demonstram não conhecer essa especificidade da prática social.

A respeito da (2) unidade semântica, elemento que compõem os aspectos globais de um texto (ANTUNES, 2010), em decorrência de apenas 6 textos apresentam a estrutura dissertativa-dissertativa, nosso entendimento é o de que a maioria das 26 produções não apresenta unidade semântica. Entretanto, vale destacar que ao considerarmos que um dos 6 textos estruturados de forma conciliada ao gênero constrói a proposta de intervenção completamente desvinculada do tema e das outras partes do texto, como pode ser visualizado pela transcrição a seguir, Nesse sentido, apenas 5 das 26 redações apresentam unidade semântica. 
Texto 5: Redação que apresenta a proposta de intervenção desvinculada das partes do texto.
Tem muitas imagens que podem sim influênciar os adolescentes, alguma delas deixam os adolescentes revoltados e outras que não.
Eu acho que os discursos tem que falar uma coisa que vale a pena, para pelo menos conseguir que ela seja vista por muitas pessoas e principalmente pela mídia para que seja um movimento muito importante.
As representações tem que ser bem organizadas tem que ter um líder que tá por dentro do assunto para que não seja uma coisa mal feita que ninguém vai ligar.
As representações deveriam ser feitas só por adolescentes que querem lutar para uma vida melhor, e não colocar pessoa que só tão lá por tá, porque eles só vão estragar as coisas que os outros já conseguiram conquistar.
O Brasil está passando por um momento muito crítico por causo dos roubos. Já mudaram de presidente sai um ruim e entra outro pior. Por isso o Brasil não sai dessa crise se não colocar pessoas que querem comandar nosso pais certo, o Brasil vai ficar nessa crise.
Vamos lutar por um país melhor.

O texto 5 além de demonstrar problema de (2) unidade semântica, revela inadequações na construção da progressão do tema (3), o que consequentemente não confere (6) relevância informativa ao texto. Embora, de um modo geral, seja preciso destacar que nenhum das 26 redações trazem "um grau de informatividade adequado às suas circunstâncias de circulação" (ANTUNES, 2010, p. 74). Isto é, por serem textos que materializam a prática social de participar de um exame de avaliação, não se coadunam totalmente ao tema proposto e ao propósito comunicativo instituído na situação comunicativa.

Sobre a construção da (7) intertextualidade, nenhum dos 26 textos apresentam uma articulação com outros textos, como posto, não trazem informações originárias de outras áreas do conhecimento, não são formados por fatos históricos e científicos. É possível apenas entender que alguns deles se relacionam de forma explícita ao comando de produção, formando paráfrases com o que está à esquerda das redações. Isto é, a orientação de Adam (2011, p. 53) é a de que para compreensão de um texto é essencial observar o que está "à esquerda e/ ou à direita" do enunciado. Assim, a constatação é a de que não há progressões significativas do tema, há em algumas redações, conforme apresentamos no quadro 1, um tipo de repetição das informações do comando de produção, que está à esquerda das redações. 


\begin{tabular}{|c|c|}
\hline Comando de produção & Alguns trechos das redações \\
\hline PROPOSTA DE REDAÇÃo & Texto 1: Sim, através de imagens, \\
Redija um texto dissertativo- & discurso e representações sociais podemos \\
argumentativo sobre o tema proposto & aprender, e sermos influenciados... \\
\cline { 2 - 2 } abaixo: & Texto 5: Tem muitas imagens que podem \\
Imagens, discursos e representações & sim influênciar os adolescentes [...]. \\
sociais presentes na mídia televisiva & Eu acho que os discursos tem que falar \\
e na web podem ser incorporadas por \\
adolescentes ao ponto de influenciar \\
comportamentos e a formação para a \\
vida adulta.
\end{tabular}

Quadro 1: Exemplo das relações de paráfrases realizadas por algumas redações

O quadro demonstra a frágil relação intertextual apresentadas pelos textos 1 e 5. Para que os alunos pudessem construir intertextualidades seria preciso que empregassem, nas redações, os saberes armazenados em suas memórias, ou seja, buscassem informações em suas memórias discursivas, uma vez que para o autor, "a memória discursiva é, ao mesmo tempo, o que permite e o que visa uma interação verbal" (ADAM, 2011, p. 57). Nesse sentido, nossa interpretação é que os alunos não possuíam muitos conhecimentos a respeito do tema. Como a intenção era de que as redações servissem de diagnóstico para a definição dos conteúdos a serem elencados como objeto de ensino e aprendizagem em sala de aula, os alunos receberam apenas essa informação, sem uma proposta de debate a respeito do tema, ou do oferecimento de textos de apoio à leitura.

\section{Aspectos mais pontuais}

De acordo com Antunes (2010) os aspectos mais pontuais dizem respeito à arquitetura do texto propriamente dita, formada pelas regularidades, ou reportando-nos aos preceitos bakhtinianos, aos elementos que formam a construção composicional e o estilo do gênero (BAKHTIN, 2003). Vale destacar que não nos ocupamos, como orienta Antunes (2010), em analisar cada um dos aspectos, nos pautamos naqueles mais característicos do gênero, com base 
em outros estudos específicos do gênero, como os de Striquer (2014) e Batista e Striquer (2016).

Partindo para observação dos (a) elementos coesivos, referenciamos, primeiramente, o fato de que a cartilha do ENEM (BRASÍLIA, 2016), que é um documento de instrução, não prescreve em nenhum momento qual pessoa do discurso o autor da redação deve empregar para organizar as ideias no texto. Logo, empregar a primeira pessoa do discurso não pode ser considerado incorreto, uma vez que o gênero requer a exposição de um ponto de vista de seu autor. Contudo, é visível que a maioria das redações que alcançam notas de 900 a 1.000, muito veiculadas pelas mídias, são construídas no modo impessoal, exigindo do autor um tom racionalista, sem exposição da subjetividade com achismos, generalizações e exemplificações subjetivas de forma explícita.

Diante dessa especificidade, ao analisarmos as 19 redações (não consideramos para a análise dos aspectos pontuais apenas as 7 redações que fugiram do tema) constatamos que nenhuma delas se organiza pelo modo impessoal. Dezoito textos empregam a primeira pessoa do discurso. Exemplos: texto 3: "penso que a mídia"; "para não fazermos"; texto 4: "as mídias nos mostram"; texto 5: "Vamos lutar". E em um outro texto o autor emprega a terceira pessoa do discurso, exemplo: texto 8: "Por isso os adolescentes tem que mudar a forma de como eles veem toda essa situação, e procurar se aprofundar mais e procurar a verdade a qualquer custo e não se deixar influenciar ao ver qualquer tipo de manifestação tanto na televisão como na internet".

O fato das 19 redações não empregarem o modo impessoal, valorizado pelo ENEM, não corresponde que estejam incorretas, só que os textos acabam por se afastar daquilo que é regular na arquitetura do gênero (ANTUNES, 2010), ou conforme defende Bakhtin (2003) do que constitui o gênero como relativamente estável. Esse afastamento se estabelece ainda mais quando em muitos dos textos dos alunos estão presentes expressões que marcam o achismo e as generalizações, como pode ser verificado nos exemplos: texto 5: "Eu acho que os discursos"; texto 7: "O mundo das pessoas de nossa sociedade, gera apenas entre televisão e web, não pensão em mais nada, somente nessas coisas". Como mencionado, a exposição da subjetividade com achismos, de generalizações e exemplificações subjetivas de forma explícita são avaliadas de forma negativa pelos responsáveis pelo ENEM. 
Sobre (g) a estratégia de utilização da substituição pronominal como mecanismo coesivo, de modo geral, as 19 redações fazem um adequado uso desse recurso. A maior parte dos textos usa expressões referenciais pronominais em ordem gramatical, no que se refere à concordância de gênero e número entre a expressão referencial e a pronominal, bem como na ordem textual, na ilação pretendida entre tais expressões. Exemplos destacados no texto a seguir:

\section{Texto 2:}

Os adolescentes são muito influênciados, por exemplo, o jogo da Baleia Azul que viralizou neste ano, muitos adolescentes que entraram nesse jogo foram influenciados e, até mesmo, obrigados a jogar por medo, os curadores, que são os "donos" do jogo, adicionam os adolescentes no facebook e ameaçam seus familiares, fazendo assim com que se sintam obrigados à participar, sem saber que esse jogo vai levá-los à morte. A mídia, as novelas e as séries, influênciam também, por que os adolescentes acham que tudo que foi passado a eles está certo, sem se informarem de que tudo pode estar absolutamente errado, eles saem fazendo o que viram, e assim acabam até infringindo leis.

Um outro elemento são (i) os conectores, sendo o gênero predominantemente composto pela sequência argumentativa (STRIQUER, 2014; BATISTA, STRIQUER, 2016), os conectores ou conjunções é que promovem a articulação entre as ideias e entre as partes essenciais: introdução com a apresentação da tese, desenvolvimento com os argumentos, e a conclusão com construção da proposta de intervenção. Nos 19 textos, o emprego desse recurso pode ser interpretado como adequado, com a verificação de problemas individuais. Apenas destacamos que dos 6 textos que apresentam a proposta de intervenção, em apenas uma redação a conjunção conclusiva é empregada como abertura do parágrafo, no texto 8: "Por isso os adolescentes tem que mudar a forma de como eles veem toda essa situação".

Exemplos do adequado emprego das conjunções podem ser expostos no que se refere ao: uso de expressões conectivas com valor semântico de exemplificação: texto 9: "Os adolescentes são muito influenciados, por exemplo, o jogo da Baleia azul"; texto 10; "Muitas vezes, acabamos sendo influenciados em alguns tópicos, por exemplo, política, classes sociais, como pensar a respeito de sexualidade"; com valor de confirmação/justificação (ANTUNES, 2010): texto 9: "adicionam os adolescentes no facebook e ameaçam seus familiares, fazendo assim com que se 
sintam obrigados à participar"; "eles saem fazendo o que viram, e assim acabam até infringindo a lei; com valor de causalidade: texto 5: "e não colocar pessoas que só tão lá por tá, porque elas só vão estragar as coisas"; texto 8: "o que pode ajudar muito a não se deixar influenciar facilmente, porque os conteúdos presentes são muito manipuladores".

Analisados alguns dos aspectos sugeridos por Antunes (2010), é necessário que apontemos ainda outros aspectos que formam as redações produzidos pelos alunos, aspectos problemáticos, visto que são prescritos como essenciais no emprego da modalidade escrita forma da língua portuguesa pela Cartilha do ENEM (BRASÍLIA, 2016):

Além dos requisitos de ordem textual - como coesão, coerência, sequenciação, informatividade -, há outras exigências para o desenvolvimento do texto dissertativo-argumentativo:

- ausência de marcas de oralidade e de registro informal;

- precisão vocabular;

- obediência às regras de - concordância nominal e verbal; - regência nominal e verbal; - pontuação; - flexão de nomes e verbos; - colocação de pronomes oblíquos (átonos e tônicos); - grafia das palavras (inclusive acentuação gráfica e emprego de letras maiúsculas e minúsculas); e divisão silábica na mudança de linha (translineação). (p. 15).

Nos textos analisados, encontramos: o mal emprego da pontuação, principalmente do uso da vírgula, exemplos: texto 5: "o que as empresas veem fazendo a muito tempo para conseguir o que querem, e terem vantagens sobre as outras pessoas"; Uso de reticências e de ponto de exclamação, o que não é comum no gênero, exemplo: texto 6: "atravez de jornais, internet, novelas, etc...; "Sejam presentes!"; Problemas com a ortografia das palavras: texto 6: "atravez"; texto 4: "veêm"; texto 12: "estrupos" - incluindo nesse item a falta de acentuação gráfica das palavras; Problemas com a concordância verbal e nominal: texto 6: "nas notícias que eles vêna mídia; texto 3: "Sendo assim a população escolhe 'soluções' influenciados pela mídia"; texto 3: "para não fazermos má escolhas"; texto 12: "os jovens de hoje se inspiram em filmes, series, novelas, etc que mostra um mundo surreal"; Problemas com a conjugação verbal: texto 6: "Pais, 
conversam com seus filhos, ajuda-os a tomarem um caminho"; texto 3: Dessa forma, penso que devemos se informar bem"; texto 4: "dependendo do que veêm em novelas, filmes, etc"; Problemas com a paragrafação, dos 19 textos, 4 são construídos em um único parágrafo; 5 em 2 parágrafos. Não que exista um número regular de parágrafos característico do plano geral do gênero redação de vestibular, contudo, em apenas dois parágrafos é muito complexo organizar a estrutura relativa que contempla o gênero.

\section{Considerações finais}

Com o objetivo de analisar as redações de ENEM, produzidas como textodiagnóstico, por 26 alunos atendidos por um projeto nosso de ensino-PIBID, tomamos os preceitos teóricos metodológicos que consideram texto, discurso e gênero de forma dissociada, conforme MARCUSCHI (2008); ANTUNES (2010) e ADAM (2011). Nossa intenção era de que tivéssemos condições, a partir dos resultados encontrados, de compreender o que os alunos já sabiam sobre a organização textual de seus discursos e o que é ainda preciso aprimorar ou levar a conhecimento dos discentes pela equipe do projeto. Os resultados demonstram que para que os alunos atendidos pelo projeto tenham um bom rendimento na produção da redação do ENEM os conteúdos a serem trabalhos em sala de aula são: A situação comunicativa da qual participa o gênero; $O$ domínio social de comunicação: discutir problemas sociais controversos - visto que 7 dos 26 textos fugiram ao tema proposto; O papel social do qual o aluno deve assumir ao produzir seu texto: o de candidato que deve alcançar uma boa nota, assegurando assim uma vaga em uma universidade pública brasileira ou em programas de bolsa para instituições particulares de ensino; O esquema de composição que organizam o texto do tipo dissertativo-argumentativo, com a prescrição de defesa de um ponto de vista a respeito do tema proposto, articulando argumentos consistentes, estruturados, bem como elaborar uma proposta de intervenção social para o problema apresentado no desenvolvimento do texto que respeite os direitos humanos - visto que dos 26 textos, 3 são formados apenas pela exposição de ponto de vista; 10 apresentam só ponto de vista e argumentos; 6 se adequam a estrutura do gênero dissertativo-argumentativo, mas de forma precária; Estratégias para que os alunos possam aplicar conceitos de diferentes 
áreas de conhecimento em suas redações, o que implica na construção de relações intertextuais; Estratégias para selecionar, relacionar, organizar e interpretar informações, fatos, opiniões e argumentos em defesa do ponto de vista; Estratégias de elaboração da proposta de intervenção detalhadas e relacionadas ao tema e articulada à discussão desenvolvida no texto; Estratégias para que os alunos tenham consciência de quem são e do papel social dos corretores das redações; Estratégias para que os alunos possam dar unidade semântica às redações, com adequada construção de continuidade, progressão, articulação e não contradição aos textos; Relevância informativa ao texto, com um grau de informatividade adequado à prática social refletida pelo gênero; Situações para formação de hábito de leitura de notícias, reportagens, textos de opinião, blogs, editoriais, textos de divulgação científica, textos relacionados às áreas de história, filosofia, sociologia, a fim de um aprimoramento da memória discursiva; Atividades para que os alunos desenvolvam a escrita empregando o modo impessoal; Mecanismos linguísticos-discursivos necessários para a construção da argumentação com o emprego do modo impessoal; dos conectores que, de forma mais específica, iniciam de forma explícita a conclusão do texto; da pontuação, priorizando o uso da vírgula; a correta ortografia, considerando a acentuação gráfica das palavras; concordância verbal e a nominal; conjugação verbal; paragrafação.

Frente ao elencado, acreditamos que a proposta metodológica sugerida por Antunes (2010), nos possibilitou de forma muito eficiente e eficaz perceber nos textos-diagnósticos elementos problemáticos na construção dos discursos e organização dos textos e de como podemos, então, ultrapassar só o diagnóstico, tendo condições de definir quais atividades são necessárias na formação de sequências didáticas para o ensino do gênero redação do ENEM.

\section{Notas}

1 Apenas para uma melhor organização na apresentação dos aspectos analisados, os identificamos da seguinte forma: os aspectos globais analisados foram marcados com a numeração de 1 a 7; e os aspectos mais pontuais receberam as letras de A a I.

20 projeto é formado por uma equipe de dois professores coordenadores, vinculados à Universidade Estadual do Norte do Paraná (UENP), quatro professores das escolas parceiras; e 22 alunos dos cursos Letras/Inglês e Letras/Espanhol da UENP, campus Jacarezinho. 
3 Não discutiremos nesse momento os problemas com os aspectos mais pontuais que formam os textos, o faremos apenas no momento de abordagem aos elementos que constituem tais aspectos.

4 Os textos produzidos pelos alunos foram transcritos exatamente como do original.

5 Quem coordena os critérios e o processo de seleção de professores para as correções das redações do ENEM é o Centro Brasileiro de Pesquisa em Avaliação e Seleção e de Promoção de Eventos (CESPE) da Universidade de Brasília.

\section{Referências}

ADAM, J.P. A linguística textual: iniciação à análise textual dos discursos. 2. ed. São Paulo: Cortez, 2011.

ANTUNES, I. Análise de textos: fundamentos e práticas. São Paulo: Parábola Editorial, 2010. BAKHTIN, M. Estética da criação verbal. Tradução Maria Ermantina Galvão G. Pereira. 4. ed. São Paulo: Martins Fontes, 2003.

; VOLOCHINOV. Marxismo e filosofia da linguagem. Tradução de Michel Lahud e Yara Frateschi. 16 ed. São Paulo: Hucitec, 2014.

BATISTA, P.C.; STRIQUER, M.S.D. A redação do ENEM: um modelo didático do gênero textual. In: REIS, S.; EGIDO, A.A. Anais [do] I Congresso Internacional da Linguística Aplicada Crítica [livro eletrônico]: linguagem, ação e transformação. Londrina: UEL, 2016, p. $985-1000$.

BRASÍLIA. Ministério da Educação. Redação no ENEM 2016: cartilha do participante. Brasília: Ministério da Educação, 2016.

DOLZ, J.; NOVERRAZ, M.; SCHNEUWLY, B. Sequências didáticas para o oral e a escrita: apresentação de um procedimento. In: SCHNEUWLY, B; DOLZ, J. Gêneros orais e escritos na escola. Tradução e organização Roxane Rojo e Gladis Sales Cordeiro. Campinas/SP: Mercado de Letras, 2004, p. 95-129.

MARCUSCHI, L.A. Produção textual, análise de gêneros e compreensão. São Paulo: Parábola Editorial, 2008.

STRIQUER, M.S.D. O Método de análise de textos desenvolvido pelo Interacionismo Sociodiscursivo. Eutomia, Recife, n. 1, v. 14, dez./2014, p. 313-334.

recebido em 29 ago. 2017 / aprovado em 31 jan. 2018

Para referenciar este texto:

STRIQUER, M. S. D. Uma análise textual dos discursos empregados no gênero redação do Enem. Dialogia, São Paulo, n. 28, p. 89-107, jan./abr. 2018. [DOI: 10.5585/Dialogia.n28.7769] 


\title{
Língua inglesa como terceira língua: considerações sobre o ensino de línguas estrangeiras para estudantes surdos na educação básica brasileira
}

\author{
English as a third language: considerations on foreign language \\ teaching for deaf students in the Brazilian basic education
}

\author{
Felipe Flores Kupske \\ Doutor em Letras. Professor do Departamento de Letras Germânicas \\ da Universidade Federal da Bahia, Salvador, BA - Brasil \\ kupske@ufba.br
}

Resumo: Ainda são poucos os estudos no Brasil que buscam deslindar o desenvolvimento de línguas estrangeiras em contextos formais de instrução por estudantes surdos. Como consequência, o ensino de língua inglesa na escola inclusiva ainda se constitui como uma prática norteada por poucas bases teóricas. Nesse sentido, este trabalho busca discutir o ensino de língua inglesa para estudantes surdos na educação básica, trazendo à tona questões de motivação, transferência linguística e de interpretação no processo de ensino. Em nosso levantamento empírico e bibliográfico, percebemos que o ensino de língua inglesa é mais complexo para o estudante surdo, pois é considerada sua terceira língua, dependente do sistema de Libras e do português. Notamos que o estudante surdo continua à margem educacional e, no caso do ensino de línguas, a situação é agravada, pois, nem sempre, tem oportunidades de interagir organicamente ou vê a língua estrangeira como relevante, dada sua configuração metodológica usual.

Palavras-chave: Surdez. Língua inglesa. Educação Básica.

\begin{abstract}
There are few studies in Brazil seeking to investigate the development of foreign languages in formal settings for deaf students. As a result, English language teaching in the inclusive school is still a practice guided by few theoretical bases. In this sense, this work aims to discuss the teaching of English for deaf students in basic education, bringing up issues of motivation, language transfer and interpretation in the teaching process. In our empirical and bibliographical analysis, we realized that the teaching of English is more complex for the deaf student as it is considered his/her third language, dependent on the systems of Libras and Portuguese. We note that deaf students continue at margin of education and in the case of language teaching, the situation is worse, because they do not always have opportunities to organically interact or see the foreign language as relevant, given its usual methodological configuration.
\end{abstract}

Keywords: Deafness. English Language. Basic Education. 


\section{Introdução}

Em 2013, recebi a gratificante e desafiadora tarefa de coordenar um curso de licenciatura em Letras com ênfase em Língua Brasileira de Sinais (Libras). Tendo minha formação acadêmica na área de línguas orais, mais especificamente, na área das línguas portuguesa e inglesa, trabalhar na formação de professores de língua de sinais (LS), sendo que a metade dos graduandos era composta por surdos, despertou inquietações sobre as quais, aos poucos, tenho me debruçado na tentativa de entendê-las. Uma dessas inquietações está relacionada à aquisição do sistema de escrita de línguas orais por estudantes surdos no contexto da educação básica brasileira. Nessa jornada de inquietudes, percebi que as pesquisas sobre o desenvolvimento da linguagem escrita do português brasileiro (PB) representam uma área do conhecimento pouco pesquisada em comparação às pesquisas em outras áreas que também envolvem a surdez. Em adição, a área do desenvolvimento de uma língua estrangeira (LE) por estudantes surdos representa uma área ainda menos pesquisada no Brasil; uma lacuna teórica.

Dessa forma, este trabalho, um gênero híbrido entre pesquisa qualitativa e desabafo de um formador de professores, tem como objetivo apresentar algumas considerações sobre o ensino de língua inglesa na educação básica brasileira para estudantes surdos, já que a formação de professores da área da língua inglesa comumente defende o desenvolvimento holístico da linguagem, que envolve o ensino de habilidades de produção e compreensão oral e escrita como modelo default de ensino. Assim, nesta pesquisa bibliográfica, trazendo ideias da área da Linguística Aplicada, busco, primeiramente, apresentar um panorama sobre o ensino da língua inglesa na educação básica. Dou continuidade, então, discorrendo sobre o ensino de língua inglesa especificamente para estudantes surdos, trazendo à tona pontos que acredito que devam ser evidenciados, como, por exemplo, problemas de motivação para o desenvolvimento de sistemas de escrita, o papel do intérprete em uma sala que envolve duas línguas orais mediadas por uma língua gesto-visual e o papel da transferência linguística entre as línguas envolvidas no processo instrucional. Apresento, também, sempre que possível, sugestões para a classe que contém estudantes surdos. Encerro, então, este trabalho expondo minhas considerações finais. Neste ponto, devo ressaltar que este artigo não busca um extenso levantamento bibliográfico de dados, mas, acima de tudo, constituir uma plataforma crítica para reflexão e debate sobre a educação de surdos no Brasil. 


\section{Um panorama sobre o ensino de língua inglesa no Brasil: a obrigatoriedade e a surdez}

O ensino de língua inglesa como disciplina obrigatória no currículo escolar brasileiro data de 1809, quando Dom João VI decreta a implantação do ensino de duas línguas estrangeiras no Brasil, o inglês e o francês, escolhidas estrategicamente, visando relações comerciais (LIMA, 2008). Nesse prisma, o início do ensino de inglês no Brasil teve como foco a conversação, buscando a capacitação de profissionais para o mercado de trabalho dadas as relações comerciais com nações estrangeiras. Em 1837, então, funda-se o Colégio Pedro II, a primeira instituição de ensino secundário do país. Desde sua fundação, incluía em sua grade curricular o ensino do inglês, francês, latim e do grego. Seguindo esse modelo, o inglês torna-se parte do currículo obrigatório das escolas secundárias em todo o país. Contudo, conforme sinaliza Lima (2008), em 1889, após a proclamação da República, Benjamin Constant implementa reformas no sistema educacional brasileiro baseadas no positivismo, corrente filosófica que considera a educação prática como anuladora das tensões sociais. Com a Reforma, o ensino deveria ser transformado para formar estudantes para os cursos superiores, além de permutar a predominância literária pela científica (LIMA, 2008). Como resultado desses movimentos, o inglês acaba sendo excluído do currículo obrigatório.

Em 1892, após o afastamento de Benjamin Constant, as LE voltam a ter caráter compulsório. Em 1898, com o ministro Amaro Cavalcanti, as disciplinas humanísticas como a filosofia, o latim e o grego adquirem grande importância em solo brasileiro (LIMA, 2008). Com essa nova reforma, o inglês passa a ser facultativo e ter uma abordagem literária. Assim, como podemos perceber, desde o século XIX, o nosso sistema educacional sofre diversas reformas, por meio das quais, por exemplo, a língua inglesa chega a ser excluída da grade curricular obrigatória, como nas Leis de Diretrizes e Bases da Educação Nacional (LDB) de 1961 e 1971. A LDB de 1961, além de alterar o currículo nacional de "ginásio" e "científico", para 1o. e 2o. graus, respectivamente, estabelece que o ensino de LE tem caráter de obrigatoriedade apenas parcial para o 1o. grau, mas recomenda a inclusão das disciplinas de LE sempre que possível. Já a LDB de 1971 reduz a duração da educação básica de doze para onze anos, sendo oito anos para o 10. grau e três para o 2o. Essa redução, além de um foco mais profissionalizante do ensino, leva a uma redução na carga horária para as LE. Para Leffa (1999), essa 
situação se agrava por meio de um parecer do Conselho Federal de que a LE seria "dada por acréscimo" dentro das condições de cada estabelecimento (LEFFA, 1999, p. 10). Como consequência desses gestos políticos, diversas instituições de ensino retiraram as disciplinas de LE do $1^{\circ}$ grau e reduziram a carga horária do $2^{\circ}$ grau para uma hora semanal.

É apenas por meio da LDB de 1996 que a LE torna-se um componente compulsório da educação básica novamente no, agora, ensino fundamental e médio. Nesse documento, o aprendizado de línguas passa a ser visto como um direito de todos os cidadãos brasileiros, cabendo ao estado a sua oferta. Para o ensino fundamental, fica clara a necessidade do ensino de uma LE, cuja escolha ficaria a cargo da própria comunidade escolar. Por outro lado, para o ensino médio, a LDB de 1996 estabelece a obrigatoriedade de uma LE moderna, existindo a possibilidade de uma segunda língua adicional optativa.

De acordo com os Parâmetros Curriculares Nacionais (PCN) de 1999, que complementam a LDB de 1996, as LE resgatam sua importância ao assumirem a condição de parte integrante do conjunto de saberes essenciais que permitem o aprendiz a aproximar-se de várias culturas e, dessa forma, propiciando sua integração no atual mundo globalizado. Todavia, não há, nos PCN, a sinalização por metodologias específicas, mas há uma inclinação a abordagens sociointeracionistas, além de um foco no desenvolvimento de habilidades de leitura em LE, já que, para os próprios PCN (BRASIL, 1999), a leitura, além de atender às demandas de uma educação formal e de ajudar no desenvolvimento integral do processo de letramento, representa a habilidade que o aprendiz pode aplicar efetivamente em seu contexto social imediato.

Neste contexto, o mesmo movimento político que reaviva a importância das LE em nosso cenário globalizado traz à tona a sua obrigatoriedade, seu caráter prescritivo. Contudo, no que concerne ao ensino de línguas na escola, Kupske e Loss (2016), por exemplo, ao analisarem narrativas de estudantes surdos acerca de sua escolarização, sinalizam que o desenvolvimento da linguagem escrita da língua nacional oral é a principal dificuldade de estudantes surdos, sobretudo para aqueles com surdez profunda e severa. Lidar com os fatos sistemáticos do português é uma tarefa complexa, pois a Libras - gesto-visual - não pode ser transcrita linearmente da mesma forma como línguas orais. Além disso, a surdez faz com que estudantes não desenvolvam a consciência fonológica, isto é, a consciência dos sons das línguas que é baseada na oralidade e nas representações dos 
sons no cérebro, que possui um papel importante na aquisição da linguagem, já que é por meio dessa que os aprendizes balizam o desenvolvimento da escrita. Nesse sentido, o ensino de língua inglesa, que envolve, por natureza, duas línguas orais naturais (inglês e PB) - e é obrigatório - deve ser pensado com cautela na educação básica que inclui estudantes surdos, e é sobre isso que nos debruçaremos a partir de agora.

\section{Inglês como terceira língua (L3) para estudantes surdos}

Nossa Constituição Federal de 1988 (BRASIL, 1988), em seu artigo $3^{\circ}$, inciso V, já apresenta, como um objetivo fundamental, "promover o bem de todos, sem preconceitos de origem, raça, sexo, cor, idade e quaisquer outras formas de discriminação.” Apresenta, também, a definição de educação como um direito de todos (Art. 205), garantindo o pleno desenvolvimento pessoal, o exercício da cidadania e a qualificação para o trabalho. O Artigo 206 estabelece, por sua vez, "a igualdade de condições de acesso e permanência na escola" como um dos princípios do ensino.

Em sintonia, as políticas nacionais de inclusão são baseadas na LDB de 1996, que define "educação especial como a modalidade escolar para educandos portadores de necessidades especiais", preferencialmente na rede regular de ensino (Capítulo V, Art. 58). Assim, os representantes governamentais, por meio de documentos oficiais, evocam a Declaração de Salamanca de 1994. A partir dessa declaração, toda Educação é especial, pois deve atender com qualidade a todos os estudantes (KUPSKE; LOSS, 2016). Na Declaração dos Direitos Humanos (ONU, 1948) e igualmente na Declaração de Salamanca (UNESCO, 1994), os estudantes surdos têm direito ao acesso ao conhecimento por meio da sua própria língua, ou seja, Libras, no caso do Brasil. Neste prisma, a inclusão de surdos na rede regular de ensino é respaldada, entre outros documentos, pelo Conselho Nacional de Educação, que institui as Diretrizes Nacionais para a Educação Básica de 2001. Ela indica "referências para a Educação Especial", tendo como foco a organização dos sistemas de ensino e a formação do professor.

Em consonância com essas diretrizes, é sancionada a Lei de $\mathrm{n}^{0} 10.436$, de 24 de abril de 2002, regulamentada pelo Decreto 5.626/2005 (BRASIL, 2005), que se volta ao atendimento dos estudantes surdos na rede regular. A partir de 
então, a Libras é reconhecida como meio natural legal de comunicação dos surdos brasileiros, determinando (Art. $3^{\circ}$ ) que é dever das instituições públicas escolares, órgãos públicos e de saúde pública garantirem o atendimento adequado aos surdos. Assim, Libras passa a ser considerada a sua língua materna, cabendo à escola disponibilizar a presença de tradutores e intérpretes de Libras e de PB.

A partir do momento em que a Libras é considerada uma língua oficial, começou a ser criada a legislação que garante a educação dos surdos. Na lei $n^{\circ}$ 10.436/2002, entende-se Libras com uma estrutura gramatical própria. Contudo, essa lei também sinaliza que a Libras não poderá substituir a modalidade escrita do PB, que torna-se a segunda língua (L2) dos surdos brasileiros. Assim, há a necessidade de se desenvolver a língua materna gesto-visual e a L2 escrita para que se possa exercer a cidadania em sua totalidade em solo brasileiro. Para aprendizes surdos, a aquisição da língua escrita do PB representa, então, a alfabetização em outra língua, que possui uma estrutura lexicogramatical completamente diferente, ao contrário do imaginário social errôneo de que Libras é PB na forma de sinais. Esse processo custoso de aquisição de L2 fica claro, por exemplo, na escrita de surdos, quando o sistema lexicogramatical de Libras se transfere para a escrita do PB, como podemos perceber pela falta de uso de preposições e conetivos ou pela inversão da ordem sintática da frase entre outras estratégias oriundas da transferência linguística.

Nessa perspectiva, a LE, para o estudante surdo, é uma terceira língua (L3) e completamente dependente da aquisição do PB como L2, pois é apenas baseado nesse sistema que o inglês-L3 poderia se desenvolver, já que o PB se torna o sistema de escrita base do estudante surdo. Nessa complexidade linguística, uma das principais dificuldades na aquisição do inglês-L3, além do próprio domínio da escrita, é seu status artificial para o aprendiz surdo. Sabemos, hoje, que é necessário que haja motivação de aprendizagem (BROWN, 2001), contudo, o estudante surdo pode tomar o uso da língua inglesa como não produtivo/orgânico ao não ver propósito comunicacional real na aquisição de uma L3 de origem oral. Dessa forma, o ensino de um segundo sistema de escrita, às vezes, é permeado pela resistência por parte dos estudantes surdos, obviamente, militando negativamente no processo de desenvolvimento das L2 e L3. Nesse sentido, acredito que, ao deparar-se com estudantes surdos, o professor de língua inglesa deve abordar a importância da língua inglesa no cenário internacional, bem como analisar 
as habilidades de escrita e leitura em PB-L2, para, então, proceder com o seu planejamento didático.

Outro ponto que reflete diretamente na motivação dos estudantes surdos na sala de aula de língua inglesa é a escolha do professor por metodologias exclusivamente baseadas nas demandas de estudantes ouvintes, norteadas pelas concepções de que apenas o trabalho com todas as habilidades de produção e compreensão das LE leva o estudante ao desenvolvimento linguístico. Para Domagala-Zysk (2013, p. 2) "a metodologia contemporânea para o ensino de línguas introduz estratégias de ensino ativas, baseadas na comunicação oral e trabalho em grupo". Com isso, há um elenco de elementos dificultadores para estudantes surdos, como, por exemplo, a velocidade rápida da interação entre os participantes, que dificulta o trabalho do intérprete e, como consequência, do acompanhamento por parte do aprendiz surdo que, por sua vez, possui um sistema perceptivo mais lento (DOMAGALA-ZYSK, 2013). Como percebemos, o estudante surdo precisa de mais tempo para assimilar uma nova língua, já que o acesso limitado à nova língua inibe a assimilação rápida de vocabulário, por exemplo. Além disso, a memória auditiva é menos útil como um auxílio no estudo de línguas. Esses aspectos assimilação de vocabulário e a falta da "voz interna" afetam, por exemplo, a fluência na leitura da L2/3. Nesse sentido, então, deve ficar claro que o tempo de processamento de leitura em LE pelo surdo é mais lento. Estudantes surdos não conseguem ler ou tomar notas enquanto observam o intérprete ou fazem leitura labial, assim, devemos sempre dar um tempo extra para que possam, por exemplo, ler o conteúdo de um slide antes de o explicarmos. Assim, nossa prática deve ser planejada a dar a esse estudante um tempo compatível com sua realidade linguística, sobretudo durante as avaliações.

O desenvolvimento comunicacional integral dos estudantes deve, sim, ser fomentado; contudo, para Miccoli (2005), além dessa visão holística do ensino do inglês, há, também, uma perspectiva que entende que desenvolver uma LE é saber utilizá-la de forma adequada de acordo com as necessidades dos aprendizes. Nessa perspectiva, muitas vezes o inglês trabalhado na escola não leva em consideração o aprendiz surdo. Assim, deveríamos, então, neste contexto, pensar no desenvolvimento de habilidades instrumentais com fins específicos de leitura, habilidade acessível ao aprendiz surdo.

Outro quesito que deve ser levado com consideração é a inter-relação entre os sistemas linguísticos de um aprendiz. Hoje, já se sabe que todas as línguas de um 
estudante, aprendidas ou em processo de desenvolvimento, irão interagir mutuamente (KUPSKE, 2016), já que criam um único sistema linguístico (FLEGE, 1995; BEST, TYLER, 2007). Assim, a transferência entre as línguas a serem aprendidas é um fenômeno natural do processo de desenvolvimento linguístico. Com estudantes ouvintes, na aula de inglês, esperamos que o PB se transfira para as estruturas adquiridas do inglês. Por outro lado, o sistema linguístico de estudantes surdos é mais complexo. No processo de aprendizagem do inglês-L3, a Libras e o PB irão interagir com essa nova língua. Assim, tanto Libras como o PB irão influenciar o inglês-L3. Grosso modo, o aprendiz surdo baseia sua aquisição da escrita do PB na gramática de Libras, e baseia o inglês-L3 no PB-L2 e em Libras-L1. Pesquisas como de Sousa (2008) sinalizam que a escrita do inglês de estudantes surdos conta com estruturas esperadas para o PB e para Libras, isto é, as três línguas estão interagindo simultaneamente. Na aula de inglês, para o surdo, há o convívio entre três línguas, e não apenas duas, como em contextos em que existem apenas estudantes ouvintes. Exemplo disso, é o uso de dicionários bilíngues. Caso um estudante surdo apresente alguma dúvida sobre algum item lexical do inglês, ele deverá procurá-lo em um dicionário escrito em PB, para, então, acionar seus conceitos consolidados via línguas de sinais.

Domagala-Zyks (2013) aponta que não ouvintes são positivos em relação à inclusão em turmas de ouvintes; contudo, sinaliza que a quantidade e qualidade da interação com professores e colegas ainda é deficitária. Nesse sentido, existem algumas estratégias que podem ser adotadas e que irão auxiliar no aprendizado de uma L2/L3 pelo estudante surdo.

No que concerne à comunicação, uma das possíveis estratégias utilizadas pelo estudante surdo é a leitura labial. Contudo, três quartos do processo é baseado na adivinhação, então, por esse motivo, uma fala clara, com uma velocidade razoável e com pistas contextuais é vital para a inteligibilidade. Em adição, durante as aulas, é necessário que os estudantes surdos possam escolher lugares privilegiados para que possam executar a leitura labial, caso queiram.

Sobre a aula em si, antes de se começar uma discussão ou de se trocar o tema discutido, contextualize para todos os alunos. Novamente, durante a aula, sobretudo de inglês-L3, deve-se sempre tentar incluir o máximo de pistas visuais para facilitar a inteligibilidade tanto do intérprete quanto do estudante surdo. Durante as aulas, usar recursos visuais é importante, como, por exemplo, handouts, lista de vocabulário, diagramas entre outros. Idealmente, o estudante 
surdo deveria receber uma lista de novas palavras a aparecerem na lição sempre que possível, já que pode afetar a leitura, bem como a leitura labial para aqueles que a fazem. Assim, as aulas que contêm estudantes surdos não devem carecer de planejamento. Se possível, por exemplo, devemos providenciar material impresso contendo o planejamento da aula para o intérprete e para o estudante surdo. Novamente, a velocidade da exposição dos dados é crucial. Deve-se tentar permitir um tempo maior para que os estudantes assimilem e respondam ao conteúdo antes de darmos continuidade. Além de checarmos a compressão constantemente, é muito importante fazermos com que os demais estudantes se organizem para falar um de cada vez, para que o intérprete possa cumprir com sua tarefa.

Além do já relatado, devemos fazer considerações acerca do papel do intérprete de Libras no ensino de inglês-L3. Geralmente, e infelizmente, os professores regulares de língua inglesa desconhecem Libras, e, além disso, os intérpretes de Libras desconhecem a língua inglesa. 0 estudante surdo, mesmo em uma aula de línguas, acaba recebendo seus insumos linguísticos na forma de Libras, exceto por conta dos textos escritos. Biotto (2016), nesse sentido, aponta que o desconhecimento da LE por conta do intérprete de Libras é um dos principais problemas enfrentados pelos aprendizes surdos na sala de línguas, corrompendo, assim, a organicidade do sistema. Para a autora, muitas vezes, a aula de língua inglesa acaba sendo um espaço no qual o estudante surdo faz outras atividades que não estão relacionadas à disciplina, pelo não entendimento do enunciado dos exercícios e/ou da fala do professor por parte do intérprete. Toda a instituição de ensino que contenha estudantes surdos tem garantido por lei o direito a intérprete de Libras. Contudo, como podemos perceber, a falta de profissionais devidamente capacitados e especializados em determinadas áreas do conhecimento pode fazer com que a educação inclusiva não tenha sucesso. Assim, os profissionais devem conhecer os três sistemas envolvidos no processo de aquisição (L1, L2 e Língua de Sinais).

Para finalizar, a Estrutura da aula também possui um papel importante. Os assentos devem ser disponibilizados de forma que os estudantes surdos tenham visão completa do intérprete e do professor. Pessoalmente, acredito que uma sala ampla, para que se forma um semicírculo/ ferradura frente ao professor e intérprete é o ideal. Por mais estranho que possa parecer, uma sala barulhenta pode atrapalhar mais um estudante surdo que de um estudante ouvinte, já que muitos podem sentir as vibrações dos sons, levando a problemas de concentração. Assim, 
idealmente, devemos optar por uma sala com o mínimo de ruídos possível. Além disso, salas altamente decoradas e com muitos estímulos visuais podem distrair os estudantes surdos.

Dessa forma, por meio deste breve relato pessoal e científico, podemos perceber que o já complexo ensino de LE se torna ainda mais desafiador para o estudante surdo. Para Gesser (2009, p. 57), "há quem pregue que o surdo não aprende conteúdos escolares porque tem mais dificuldades que os ouvintes [...] não se trata de dificuldade intelectual e sim oportunidade" e isso fica ainda mais evidente na sala de aula de língua inglesa. Notamos que o estudante surdo continua à margem educacional e, no caso do ensino de línguas, a situação é agravada, pois, nem sempre, tem oportunidades de interagir organicamente ou vê o ensino de LE como relevante, dada sua configuração metodológica usual. Muito embora os cursos de licenciatura, hoje, devam disponibilizar disciplinas de Libras como parcela integrante da formação de professores, as poucas horas ainda destinadas aos componentes surtem pouco efeito na prática do ensino de línguas. Contudo, acreditamos que qualquer professor de língua inglesa, ao fazer pequenas adequações em sua aula, levando em consideração as consideração aqui destacadas, ou fazendo o estudante surdo perceber a importância da língua inglesa em nossa sociedade globalizada, será capaz de não apenas "incluir" o estudante surdo, mas dar acesso a um novo mundo e a novas culturas por meio da leitura em língua inglesa.

\section{Considerações Finais}

O movimento de inclusão na/para educação formal faz parte de uma ação política, cultural, social e pedagógica que defende uma educação em que todos participem e aprendam sem discriminação. A Política Nacional de Educação Especial, na perspectiva da educação inclusiva (BRASIL, 2008), acompanha os avanços do conhecimento científico e das lutas sociais na busca por alternativas para que se supere a discriminação e para que se promova uma educação de qualidade e proporcional a todos. Contudo, muito ainda há a ser feito. No que concerne ao ensino da língua inglesa para estudantes surdos - obrigatório em solo nacional, percebemos pela própria lacuna de pesquisas na área, que ainda estamos balbuciando tanto em teoria como na prática. Neste artigo, como sina- 
lizado em minha introdução, que tem um pouco de desabafo e um pouco de pesquisa bibliográfica, busquei apenas levantar algumas questões que, segundo minha experiência em cursos de Letras - Inglês e Letras - Libras, não são tratadas durante o processo de formação de professores. Tentei, aqui, não trazer pesquisas que representam o estado-da-arte e, muito menos, apresentar exaustivamente os problemas enfrentados por estudantes surdos na educação básica brasileira; tentei, sim, problematizar, levantar questionamentos empíricos inicias na esperança de trazer à tona questões e não respostas. Fica, então, minha sugestão - e apelo para que pesquisas nessa temática do ensino de LE para aprendizes surdos sejam fomentadas.

\section{Referências}

BEST, C.; TYLER, M. Nonnative and second- language speech perception commonalities and complementarities. In: BOHN, O.; MUNRO, M. Language experience in second language speech learning: in honor of James Emil Flege. Amsterdam: John Benjamins, 2007. p. 13-34.

BIOTTO, F. A aprendizagem da língua inglesa - L3 na educação básica por estudantes surdos. Trabalho de Conclusão de Curso (Letras - Libras). Universidade Comunitária da Região de Chapecó, 2016.

BRASIL. Constituição da República Federativa do Brasil de 1988, de 5 de outubro de 1988. Brasília, DF, 1988. Disponível em: < http://www.planalto.gov.br/ccivil_03/constituicao/ constituicao.htm>. Acesso em: 19 mar. 2018.

BRASIL. Ministério da Educação Média e Tecnológica. Parâmetros curriculares nacionais, códigos e suas tecnologias: língua estrangeira moderna. Brasília: MEC, 1999.

Ministério da Educação. Decreto n. 5.626 - Regulamenta a Lei no 10.436, de 24 de abril de 2002, que dispõe sobre a Língua Brasileira de Sinais - Libras, e o art. 18 da Lei no 10.098, de 19 de dezembro de 2000. Brasília, 2005.

Ministério da Educação. Secretaria de Educação Especial. Política Nacional de

Educação Especial na perspectiva da Educação Inclusiva. Brasília, DF: MEC/SEESP, 2008.

BROWN, H. D. Teaching by principles: an interactive approach to language pedagogy. USA: Longman, 2001.

DOMAGALA-ZYSK, E. English as a foreign language for the deaf and hard-of-hearing persons in Europe. Lublin: Wydawnictwo KUL, 2013.

FLEGE, J. E. Second language speech learning: Theory, findings, and problems. In: STRANGE, W. (Ed.). Speech perception and language experience: issues in crosslanguage research (pp. 233-277). Baltimore: York Press, 1995. 
GESSER, Audrei. LIBRAS? : que língua é essa? : crenças e preconceitos em torno da língua de sinais e da realidade surda. São Paulo: Parábola Editorial, 2009.

KUPSKE, F.; LOSS, J. O ensino médio aos olhos da surdez: uma análise de narrativas. Dialogia, São Paulo, n. 23, p. 59-68, jan./jun. 2016.

KUPSKE, Felipe Flores. Imigração, atrito e complexidade: a produção das oclusivas surdas iniciais do inglês e do português por sul-brasileiros residentes em Londres. Porto Alegre: UFRGS. Tese (Doutorado) - Letras, 2016.

LIMA, G. Breve trajetória da língua inglesa e do livro didático de inglês no Brasil. Anais... VII Seminário de Pesquisa em Ciências humanas. Londrina, 2008.

LEFFA, Vilson J. O ensino de línguas estrangeiras no contexto nacional. Contexturas, APLIESP, n. 4, p. 13-24, 1999.

MICCOLI, Laura Stella. Autonomia na Aprendizagem de Língua Estrangeira. In: PAIVA, Vera Lúcia M. O. (Org.). Práticas de ensino e aprendizagem de inglês com foco na autonomia. São Paulo: Pontes, 2005.

ORGANIZAÇÃO DAS NAÇÕES UNIDAS (ONU). Declaração Universal dos Direitos

Humanos. 1948. Disponível em: < https://www.unicef.org/brazil/pt/resources_10133.

htm>. Acesso em: 19 mar. 2018.

SOUSA, A. Surdos Brasileiros escrevendo em inglês: uma experiência com o ensino comunicativo de línguas. Dissertação (Mestrado) - Linguística Aplicada. Universidade Estadual do Ceará, 2008.

UNESCO. Declaração de Salamanca: Sobre Princípios, políticas e práticas na área das necessidades educativas especiais. 1994.

recebido em 31 ago. 2016 / aprovado em 7 fev. 2017

Para referenciar este texto:

KUPSKE, F. F. Língua inglesa como terceira língua: considerações sobre o ensino de línguas estrangeiras para estudantes surdos na educação básica brasileira. Dialogia, São Paulo, n. 28, p. 109-120, jan./abr. 2018. [DOI: 10.5585/Dialogia.n28.6722] 


\title{
Contribuições do processo reflexivo para o entendimento da prática docente
}

\author{
Contributions from the reflexive process for the \\ understanding of the teaching practice
}

\author{
Eliana Alves Arxer \\ Mestre em Educação. Professora de Química na Rede Estadual de São Paulo \\ e de Matemática na rede Municipal de Araraquara, São Paulo - Brasil \\ nana_unesp@yahoo.com.br
}

Dulcimeire Ap. Volante Zanon

Doutora em Educação. Professora do Programa de Pós-Graduação Profissional em Educação da Universidade Federal de São Carlos, São Paulo - Brasil dulci@ufscar.br

\author{
José Luís Bizelli \\ Doutor em Sociologia. Professor Adjunto da Universidade \\ Estadual Paulista de Araraquara, São Paulo - Brasil \\ bizelli@fclar.unesp.br
}

\begin{abstract}
Resumo: Este artigo tem como objetivo apresentar discussões sobre o processo reflexivo a partir de uma situação de ensino intitulada "energia elétrica e ano internacional da luz", de acordo com a perspectiva CTS (Ciência - Tecnologia - Sociedade) da abordagem de conteúdos, a fim de favorecer o entendimento da prática docente. A professora pesquisadora elaborou o planejamento e a execução das atividades, em seis etapas, junto a alunos de duas turmas de nono ano do Ensino Fundamental durante as aulas de Matemática. O registro em vídeo de cada etapa, bem como os registros escritos dos envolvidos - professora, interlocutora e alunos - foram analisados de forma qualitativa, considerando-se referenciais de Schön e Alarcão. Dentre as contribuições do processo reflexivo ressaltamos que, ao pesquisar sua própria prática, o professor tende a sair de sua "zona de conforto" e enfrentar as próprias angústias relacionadas à profissão, além disso, permite a reconstrução de teorias e concepções de ensino.
\end{abstract}

Palavras-chave: Processo reflexivo. Formação docente. Metarreflexão.

\begin{abstract}
This article aims to present discussions about the reflexive process from a teaching situation entitled "electric energy and international year of light", according to the perspective STS (Science - Technology - Society) of the approach of content, in order to promote the understanding of the teaching practice. The teacher researcher prepared the planning and implementation of activities in six steps, along with students from two classes of ninth grade in Basic Education during the lessons of mathematics. The record in video for each step as well as the written records of those involved - teacher, observer teacher and students - were analyzed in qualitative way, considering the theoretical referential of Schön and Alarcão. Among the contributions of the reflexive process we emphasize that, when searching for your own practice, the teacher tends to go out of their "comfort zone" and face their own fears related to the profession, moreover, allows the reconstruction of theories and conceptions of teaching
\end{abstract}

Keywords: Reflexive process. Teacher training. Meta-reflection. 


\section{0 professor pesquisador de sua prática e o processo reflexivo}

A pesquisa e a profissão docente, de certo modo, sempre estiveram interligadas, pois para se ensinar é necessário saber e para saber é necessário adquirir a informação, seja por pesquisa ou por experiência. Quando o professor direciona a pesquisa para a própria prática, adquire uma maturidade profissional importante para o aprimoramento dessa prática, assim como aumenta as possibilidades do sucesso educacional.

Em seus diversos trabalhos, Nóvoa (1992, 2000, 2009) reporta-se à prática docente como herança histórica dos primórdios, onde os sábios ensinavam seus discípulos. Embora o processo de ensino e aprendizagem remeta a uma era arcaica, a preocupação com a formação docente é originada, relativamente, há pouco tempo, tornando-se mais evidente no século XX e XXI.

No que se refere à reflexão sobre a prática, Dewey (1959), um precursor, retrata sua importância, ao nível da formação de professores, como sendo uma avaliação contínua de crenças, princípios e hipóteses perante um conjunto de dados e de possíveis interpretações dos mesmos. Para ele, a capacidade de refletir surge quando se está diante de um problema e pretende-se resolvê-lo. Dessa forma, a reflexão é uma ação que se dá espontaneamente a partir de uma situação problemática, opondo-se assim, as atitudes pré-estabelecidas tecnicamente.

Discussões sobre os processos reflexivos têm sido intensificadas a partir das obras de Schön $(1992,1997,2000)$ que, embora direcionadas a outra profissão, foram adaptadas à educação, ampliando a aplicação de sua teoria para a discussão no campo da atuação e formação docente.

Autores como Alarcão (2003, 2005), Ghedin (2012) e Zeichner (2008) afirmam que, para melhorar a capacidade de ensinar, o professor precisa se autoavaliar. As qualidades de um prático reflexivo são: refletir sobre a própria prática, o que requer pensar no que se faz, comprometer-se com a profissão, ser autônomo, atender e interpretar o contexto de trabalho; adaptar-se às condições necessárias para a prática reflexiva, questionar a escola, o currículo, o trabalho, o planejamento (ZEICHNER, 2008). Assim, é necessário que o professor se mobilize e encontre meios para enfrentar as dificuldades do cotidiano e transpor didaticamente sua reflexão para sua prática educacional, observando-se como um sujeito ativo no processo, ao mesmo tempo que objeto de observação. Para isso, é 
necessário um distanciamento de sua própria prática para a observação exterior (ARXER, 2015).

Acreditamos que ao refletirmos sobre uma ação, poderemos compreendê-la e, com isso, gerar transformação na prática docente. Neste trabalho, visamos apreender a situação em estudo, "energia elétrica e ano internacional da luz", a partir da perspectiva Ciência - Tecnologia - Sociedade (CTS) da abordagem de conteúdos, a fim de identificar contribuições do processo reflexivo para o entendimento da docência.

\section{A perspectiva CTS da abordagem dos conteúdos}

A perspectiva CTS iniciou-se na década de setenta, marcada por um contexto calcado na crítica a um modelo de desenvolvimento científico e tecnológico, cujos efeitos começam a afetar cada vez mais a vida das pessoas. Nesse período começaram a surgir orientações curriculares que priorizavam, entre outros aspectos, a implementação de projetos CTS no sistema escolar em países europeus e nos EUA (SANTOS, 2008).

Um dos objetivos do ensino CTS é reverter a visão negativa que se tem das ciências, com o intuito de instigar o interesse pelos assuntos científicos, "particularmente pelos alunos brilhantes e criativos que são muitas vezes desencorajados por um currículo tedioso e irrelevante" (AIKENHEAD, 1994, p. 49). Outro aspecto que merece destaque nessa abordagem é a interdisciplinaridade, uma vez que os conhecimentos não são apresentados como simples unidades isoladas de saberes, mas sim, inter-relacionam, contrastam, complementam, ampliam e influem uns nos outros.

Para que as relações CTS sejam favorecidas, faz-se necessário usar recursos e estratégias didáticas diferenciadas como palestras, demonstrações, sessões de questionamento, solução de problemas e experimentos de laboratório, jogos de simulação e desempenho de papéis, fóruns e debates, projetos individuais e de grupo, redação de cartas para autoridades, pesquisa de campo do trabalho, palestrantes convidados e ação comunitária.

Nesse sentido, o docente faz o intermédio da relação aluno-aprendizagem, auxiliando-o a construir e (re)significar os conhecimentos dos alunos a partir de estratégias mais dinâmicas, atuando como agente ativo. Ou seja, o professor é o 
grande articulador para a mobilização dos saberes e para o desenvolvimento do processo de aprendizagem, tendo a finalidade de despertar o interesse, a postura crítica e questionadora no aluno para exercer a cidadania.

Entretanto, a utilização deste tipo de abordagem, embora seja útil no processo de ensino e aprendizagem, ainda é pouco usada na prática docente (AMARAL et al., 2009). Para estes, um possível motivo seria o fato de os currículos e livros textos ignorarem a maioria das discussões centrais sobre as relações CTS.

Desta forma, concordamos com Castelli (2010), que afirma ser necessário o rompimento das "amarras" da "zona de conforto", onde os modelos metodológicos ultrapassados comprometem um ensino de qualidade, o que faz com que permaneçam na execução de uma prática pedagógica distante da dialógica, ação-reflexão-ação, por meio do conhecimento científico e da prática cotidiana.

\section{Percurso metodológico}

A obtenção dos dados ocorreu no período letivo escolar regular (vespertino), junto a duas turmas de nono ano, com idades entre 14 e 17 anos, em uma escola municipal de Ensino Fundamental II de uma cidade do interior do Estado de São Paulo, localizada na periferia, envolvendo 42 alunos. A professora que é uma das pesquisadoras deste artigo, atua na rede básica de ensino na disciplina de Matemática. Cabe destacar que uma professora interlocutora acompanhou o desenvolvimento das atividades e favoreceu as discussões do processo reflexivo.

Elegemos a temática "energia elétrica e ano internacional da luz", pois o ano de 2015 foi assim designado na $68^{\circ}$ sessão das Nações Unidas em 2013 como o "Ano Internacional da Luz" (International Year of Light) e foi celebrado em diversos países, como tema da atualidade para o ano. Além disso, esse tema está presente na vida cotidiana dos alunos, principalmente devido ao racionamento de energia no Estado de São Paulo.

O planejamento e a execução das atividades ocorreu em seis etapas, de acordo com o ciclo investigativo que considera a tríade CTS, conforme Figura 1.

Assim, tais etapas, de acordo com a temática foram estruturadas da seguinte forma: 


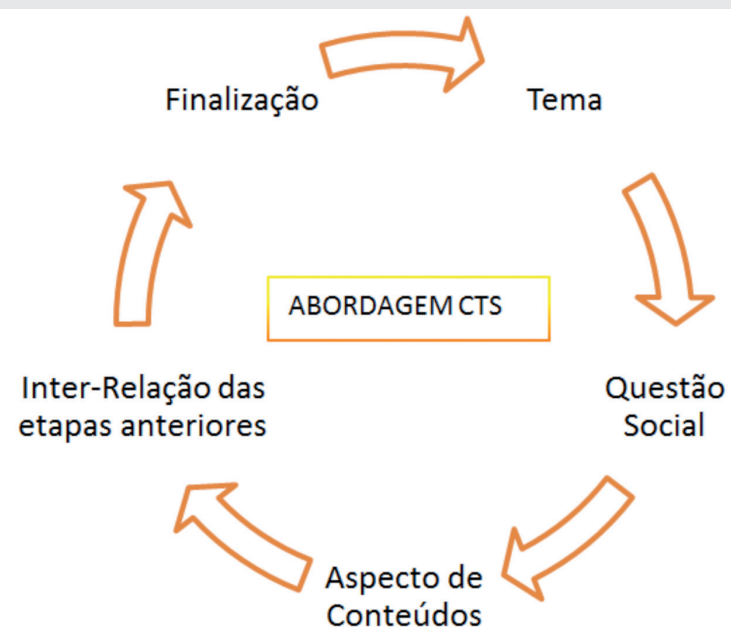

Figura 1: Etapas não lineares da Abordagem CTS Fonte: Elaborado pelos autores.

1) Contextualização da temática: charges e texto informativo;

2) Construção coletiva de questões com impacto social;

3) Investigação sobre as tecnologias envolvidas no processo de geração de energia elétrica e fontes alternativas de geração de energia;

4) Abordagem de conteúdos de Matemática articulados com a temática;

5) Inter-relação das etapas anteriores: jogo de tabuleiro humano, debate e palestra com um profissional da Companhia de Força e Luz - CPFL;

6) Finalização: roda de conversa, discussão dos principais tópicos da aprendizagem acerca da temática e aplicação de questionário junto aos alunos.

Nesse sentido, a reflexão foi realizada mediante instrumentos que viabilizassem a autoanálise como vídeo, diário de bordo (registros pela professora, caracterizando um olhar para dentro de si), escrita da professora interlocutora e roda de conversa com alunos. Esses instrumentos foram analisados a partir dos quatro momentos reflexivos de Schön (1992, 1997 e 2000), conforme Figura 2.

A reflexão antes da ação compreende o planejamento, a observação, a expectativa e os passos que norteiam a prática da ação. Já a reflexão na ação é o momento em que o professor reflete e se orienta para a tomada de decisões, cabendo a ele examinar sua prática enquanto atua, permitindo-se surpreender 


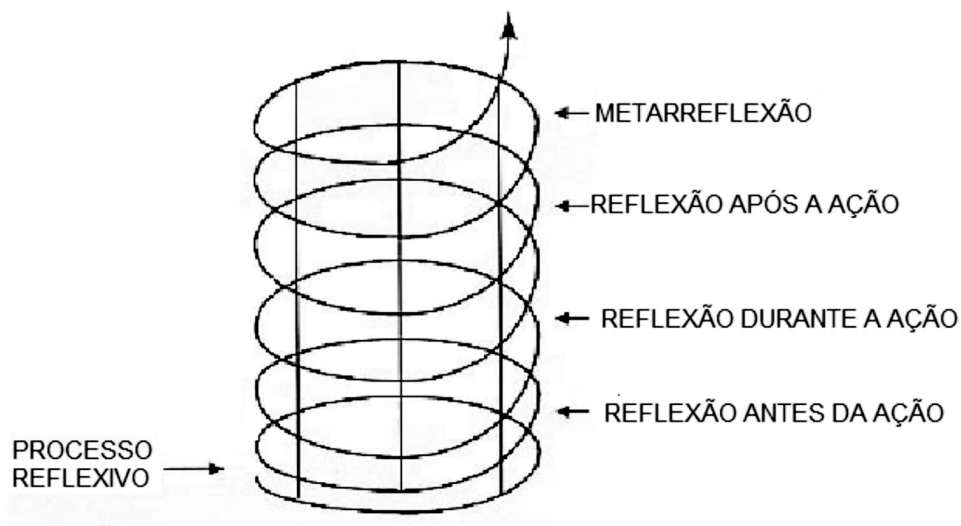

Figura 2: Espiral com os momentos reflexivos de Schön (1992)

Fonte: Adaptado pelos autores.

pelas observações explicitadas dos alunos e aprender a reconstruir e (re)significar conhecimentos. A reflexão após a ação permite ao professor refletir sobre tudo o que ocorreu, a partir de questões, como: "Como o aluno me viu?", "Como eu me vi?", "Como foi minha aula hoje?", "Como estava minha sala hoje?", "Como abordei o conteúdo planejado?", "Oportunizei espaço para que os alunos participassem?", "Como me senti hoje?", "Sobrecarreguei com conceitos e conteúdos?", "Valorizei as participações dos alunos?" (SCHÖN, 1992). Por fim, no momento de reflexão sobre a reflexão na ação ou metarreflexão, o professor analisa a totalidade do processo reflexivo, observando de forma principal a reflexão do conjunto, faz anotações sobre o que e como a ação ou o ato de ensinar ocorreu. Para isto, deverá se distanciar de si mesmo e, com um olhar de observador, analisar criticamente as decisões tomadas do planejamento à reflexão pós-ação. Esta reflexão situa o contexto, as limitações, os avanços e retrocessos em busca de uma prática mais consciente mediante as necessidades dos alunos. Para este artigo, o foco reside na última etapa, a metarreflexão.

Além da espiral adaptada dos momentos reflexivos de Schön (1992) para a análise do planejamento e do processo, utilizamos a espiral reflexiva de Alarcão (2005), representada na Figura 3.

A partir desses espirais reflexivos, o professor pode nortear suas ações de forma a observar panoramicamente as situações de ensino e aprendizagem e os objetivos finais da autorreflexão. 


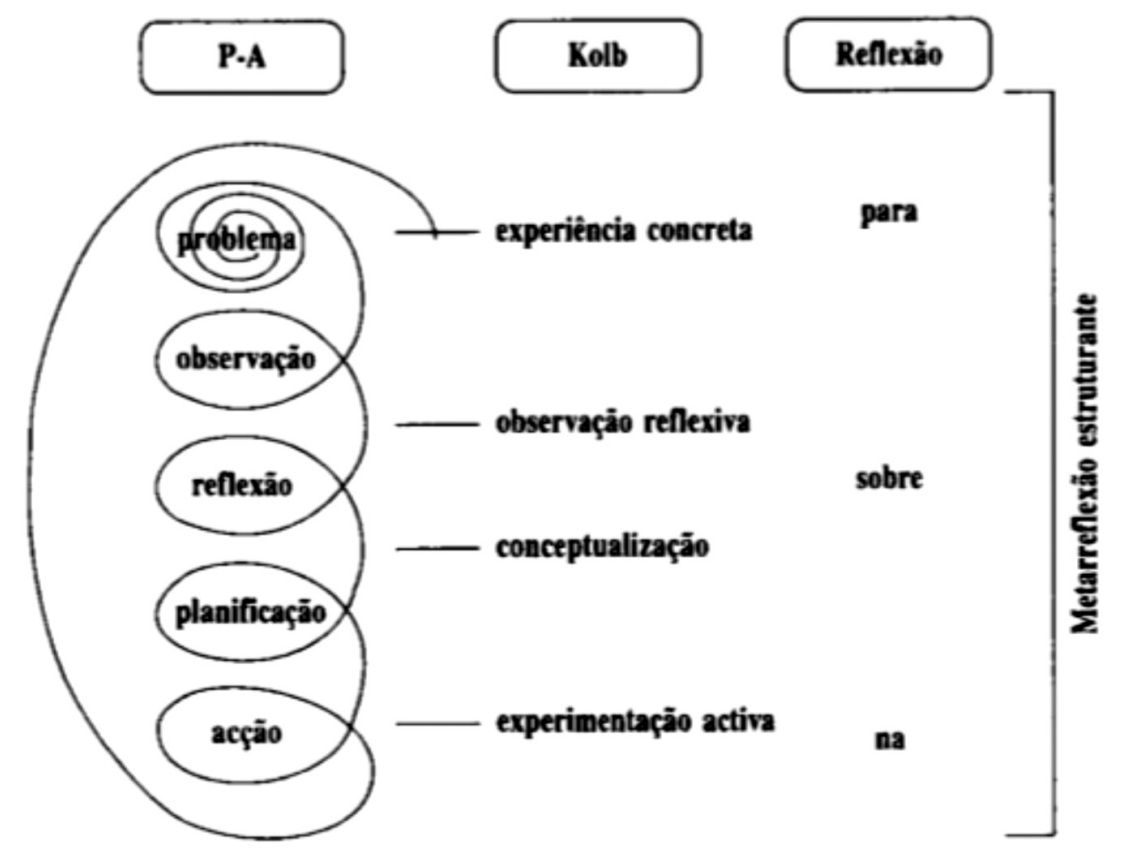

Figura 3: A metarreflexão em espiral Fonte: Alarcão, 2005, p. 48.

\section{Resultados e discussões}

Entendemos que cada momento reflexivo é importante para a constituição do profissional que reflete sobre a própria prática, para a autoanálise e mudança na postura a ser adotada pelo professor. De acordo com Alarcão,

para que a dimensão formadora atinja um alto grau formativo e um valor epistêmico, resultando em aquisição de conhecimentos a disponibilizar em situações futuras, importa que esse processo seja acompanhado por uma metarreflexão sistematizadora das aprendizagens ocorridas (2003, p. 50).

Partindo dessa premissa, as reflexões feitas pela professora advindas da análise de cada etapa foram: 
- Etapa 1: saber ouvir os alunos e interagir com eles;

- Etapa 2: saber conduzir a discussão para construção coletiva;

- Etapa 3: superar a ideia de explicar e controlar e da fragmentação do conteúdo;

- Etapa 4: contextualizar para auxiliar na interpretação e aplicação de conteúdos de matemática;

- Etapa 5: motivar a participação dos alunos ao argumentar e defender uma ideia, provocar motivação;

- Etapa 6: estar aberta às opiniões, sugestões e críticas dos envolvidos.

Diante de tais desafios e da análise da escrita da professora interlocutora (abertura à exposição de ideias pelos alunos e valorização de argumentos; elaboração de perguntas reflexivas) e alunos (mudança na prática da professora, aprendizagem de conteúdos) foi possível identificar elementos que apontam implicações da abordagem CTS sobre a prática docente da professora.

As estratégias utilizadas foram importantes para a participação ativa dos alunos, a fim de despertar o espírito crítico acerca do consumo excessivo de energia elétrica, impostos e tarifas em boletos de pagamento da conta energética, por exemplo. Além disso, a escolha de um tema introdutório para a aprendizagem de conteúdos auxiliou na ruptura de uma visão simplista anterior à aplicação das atividades pela professora. O planejamento também foi essencial nesse processo, já que ao propor estratégias, elaborar materiais e auxiliar na construção de conhecimentos pelos alunos, há uma projeção futura de ações coletivas e individuais.

A análise do processo (conforme Figura 2) favoreceu a reflexão sobre a prática profissional da professora, caracterizada por uma abordagem tradicional de ensino com aulas expositivas. Desta forma, a espiral de Alarcão que envolve:

$$
\text { PROBLEMA } \rightarrow \text { OBSERVAÇÃO } \rightarrow \text { REFLEX̃̃O } \rightarrow \text { PLANIFICAÇÃO } \rightarrow \text { AÇÃO }
$$

favoreceu a internalização das seguintes situações, conforme Figura 4.

Após planejar e executar as atividades de acordo com a perspectiva CTS, foi possível identificar mudanças na postura da professora em sala de aula, principalmente no que concerne à interação com os alunos e, consequentemente, maior oitiva. De forma mais aprofundada, categorizamos os elementos analisados, considerando os pressupostos da perspectiva CTS e da prática reflexiva em relação 


\section{Problematizar a prática profissional; \\ Observação interna e externa sobre a prática; \\ Reflexão: Como posso melhorar? Como proceder? \\ Planejamento para melhoria na qualidade da prática profissional; \\ Agir com qualidade.}

\section{Figura 4: Adaptação da espiral ação-reflexão-ação}

Fonte: Elaborado pelos autores.

à prática docente, a participação dos alunos e ao ensino de Matemática, conforme Quadro 1 e detalhamentos a seguir:

\begin{tabular}{|c|c|c|c|c|}
\hline & \multicolumn{2}{|c|}{ Perspectiva CTS } & \multicolumn{2}{|c|}{ Prática Reflexiva } \\
\hline & Pressupostos & Durante a SD & Antes a SD & Durante a SD \\
\hline $\begin{array}{l}\text { Prática } \\
\text { docente }\end{array}$ & $\begin{array}{c}\text { Professor } \\
\text { problematizador, } \\
\text { mediador do } \\
\text { conhecimento. }\end{array}$ & $\begin{array}{c}\text { Professora } \\
\text { problematizadora, } \\
\text { indução de } \\
\text { pensamento crítico } \\
\text { e contextualizado. }\end{array}$ & $\begin{array}{c}\text { Aulas } \\
\text { predominantemente } \\
\text { expositivas. }\end{array}$ & $\begin{array}{c}\text { Aulas com } \\
\text { abordagens } \\
\text { investigativas e } \\
\text { colaborativas. }\end{array}$ \\
\hline $\begin{array}{l}\text { Aprendizagem } \\
\text { dos alunos }\end{array}$ & $\begin{array}{l}\text { Participação mais } \\
\text { ativa com vistas em } \\
\text { processos decisórios } \\
\text { e formação } \\
\text { consciente. }\end{array}$ & $\begin{array}{c}\text { Participação } \\
\text { ativa em todas as } \\
\text { etapas da SD; das } \\
\text { estratégias que } \\
\text { simulam processos } \\
\text { decisórios e } \\
\text { conscientes. }\end{array}$ & Alunos passivos. & $\begin{array}{c}\text { Participação } \\
\text { e motivação } \\
\text { evidentes. }\end{array}$ \\
\hline $\begin{array}{l}\text { Educação } \\
\text { matemática }\end{array}$ & $\begin{array}{l}\text { Problematizadora, } \\
\text { inclusões das } \\
\text { relações CTS; } \\
\text { utilização de } \\
\text { elementos que } \\
\text { estimulem a } \\
\text { crítica dos alunos. } \\
\text { Contextualizada. }\end{array}$ & $\begin{array}{c}\text { Problematizadora; } \\
\text { consideração das } \\
\text { relações CTS e do } \\
\text { contexto do aluno. }\end{array}$ & $\begin{array}{c}\text { Realizada de } \\
\text { forma tradicional; } \\
\text { planejamento } \\
\text { com estratégias } \\
\text { convencionais } \\
\text { pertinentes a este } \\
\text { modelo. }\end{array}$ & $\begin{array}{c}\text { Planejamento } \\
\text { mais elaborado, } \\
\text { com inclusões } \\
\text { de estratégias } \\
\text { diferenciadas; } \\
\text { preocupação } \\
\text { com a interação } \\
\text { professor-aluno. }\end{array}$ \\
\hline
\end{tabular}

\section{Quadro 1: Categorias de análise}

Fonte: Elaborado pelos autores.

De modo geral, é possível afirmar que a professora atuou no sentido de promover a reflexão e a criticidade pelos alunos no ensino de Matemática, contextualizou o estudo a partir da realidade dos mesmos e favoreceu sua 
participação ativa e colaborativa na realização das atividades. No que se refere à prática docente, anteriormente caracterizada de acordo com a abordagem de ensino tradicional e expositivo, a partir dos pressupostos CTS, tornou-se mais problematizadora, investigativa e reflexiva. 0 ensino de Matemática foi mais bem planejado com a preocupação de relacionar recursos e estratégias diferenciadas e favorecer a interação professor-aluno. Esses fatores, associados ao deslocamento da participação dos alunos de passiva para ativa e colaborativa, despertaram a motivação docente.

\section{Considerações finais}

O professor atuante na educação básica, principalmente no setor público, nem sempre tem disponibilidade de tempo para a realização da autorreflexão (ANDRÉ, 2001). Nesse sentido, algumas situações precisam ser superadas como o paradigma dominante na escola tradicional, a burocratização escolar, a falta de planejamento, o excesso de trabalho e aulas em muitas jornadas de trabalho, pois dificultam a formação de um profissional não reflexivo. Depende da autonomia de cada profissional em permitir uma autoavaliação e analisar as implicações de sua prática para que esta não seja meramente instrumento para se avaliar a execução de um currículo.

Neste trabalho, a avaliação reflexiva foi possível, mas difícil para a professora, pois rever cada reflexão nos registros escritos (da pesquisadora e da professora interlocutora), bem como das postura nos vídeos e posterior transcrição exigiram a "tomada de consciência no sentido de algumas posturas e condutas profissionais, abrindo caminhos para as tentativas de enfrentamento das contradições vividas" (SUDAN, VILLANI; FREITAS, 2006, p. 13). A professora, voltada para a reflexão sobre sua prática pedagógica, teve o cuidado de buscar ações e estratégias diversificadas para uma melhor abordagem do tema e com significação para os alunos. Neste sentido, o exercício da reflexão sobre a prática permitiu evidenciar um distanciamento de um ensino com características predominantemente de uma abordagem tradicional e expositiva, como era exercida anteriormente pela professora.

Dentre as contribuições do processo reflexivo, podemos destacar as implicações diretas na prática pedagógica, já que permite a reconstrução de teorias 
e concepções de ensino, embora entendamos que o processo de mudanças seja lento, exigindo persistência e força de vontade do professor.

\section{Referências}

AIKENHEAD, G. What is STS science teaching? In: SOLOMON, J.; AIKENHEAD, G. STS Education: international perspectives on reform. New York: Teachers College Press, 1994. p. 47-59.

ALARCÃO, I. Professores reflexivos em uma escola reflexiva. 2. ed. São Paulo: Cortez, 2003.

ALARCÃO, I. A formação do professor reflexivo. IN: uma escola reflexiva. São Paulo: Cortez, 2005. p. 40-59. . Professores reflexivos em

AMARAL, C. L. C; XAVIER, E. S.; MACIEL, M. L. Abordagem das relações Ciência/Tecnologia/ Sociedade nos conteúdos de funções orgânicas em livros didáticos de química do ensino médio. Investigações em Ensino de Ciências, v. 14 n. 1, p. 101-114, 2009.

ANDRÉ, M. Pesquisa em educação: buscando rigor e qualidade. Cadernos de Pesquisa, n. 113, p. 51-64, julho/2001. Disponível em: < http://www.scielo.br/pdf/cp/n113/a03n113> Acesso em: 20 jul. 2016.

ARXER, E. A. A abordagem aos conteúdos de ensino na Educação Básica com ênfase nas relações CTS: implicações na prática docente. 2014. Dissertação (Mestrado Profissional em Educação) - Universidade Federal de São Carlos, São Carlos, 2014.

CASTELLI, M. D. B. A reflexão sobre a prática pedagógica: processo de ação e transformação. In: VIII Encontro de pesquisa em educação da região Sul. AnpedSul. Londrina. Anais. Londrina. 2010. Disponível em: <http://www.portalanpedsul.com.br/admin/uploads/2010/ Educacao_Basica/Trabalho/02_01_00_A_reflexao_sobre_a_pratica_pedagogica processo_de_acao_e_transformacao.PDF>. Acesso em: 20 maio 2016.

DEWEY, J. Como pensamos: como se relaciona o pensamento reflexivo com o processo educativo (uma exposição). 3. ed. São Paulo, Companhia Editora Nacional, 1959.

GHEDIN, E. Professor reflexivo: da alienação da técnica à autonomia da crítica. In: PIMENTA, S; G.; e GHEDIN, E. Professor reflexivo no Brasil: gênese e crítica de um conceito. São Paulo: Cortez, 2012. p.148-173.

NÓVOA, A. Formação de professores e profissão docente. In: NÓVOA, A. Os professores e a sua formação. Lisboa: Instituto de Inovação Educacional, 1992. p. 15-34.

. Os professores: um "novo" objecto da investigação educacional. In: NÒVOA, António. Vidas de Professores. Lisboa: Porto Editora, 2000. p. 14-17.

Professores: imagens do futuro presente. Educa: Lisboa, 2009. 
SANTOS, W. P. Educação científica e humanística em uma perspectiva freireana: resgatando a função do Ensino CTS. Alexandria Revista de Educação em Ciência e Tecnologia, v. 1, n. 1, p. 109-131, mar./2008.

SCHÖN, D. Formar professores como profissionais reflexivos. In: NÓVOA, A. (coord.). Os professores e a sua formação. Lisboa: Instituto de Inovação Educacional, 1992. p. 77- 91.

Os professores e sua formação. Lisboa, Portugal: Dom Quixote, 1997.

Educando o profissional reflexivo. Um novo design para o ensino e a aprendizagem. Porto Alegre: Artmed, 2000.

SUDAN, D; VILLANI, A; FREITAS, D. Professor-pesquisador: o caso da professora Flora. Anais. 29a Reunião anal da Anped. Caxambu, MG. out. 2006. Disponível em: < http://29reuniao. anped.org.br/trabalhos/trabalho/GT08-2617--Int.pdf > . Acesso em: 10 ago. 2016.

ZEICHNER, K. M. Uma análise crítica sobre a "reflexão" como conceito estruturante na formação docente. Educação e Sociedade, v. 29, n.103, p. 535-554, maio/ago.2008.

recebido em 5 set. 2016 / aprovado em 7 fev. 2017

Para referenciar este texto:

ARXER, E. A.; ZANON, D. A. V.; BIZELLI, J. L. Contribuições do processo reflexivo para o entendimento da prática docente. Dialogia, São Paulo, n. 28, p. 121-132, jan./abr. 2018. [DOI: 10.5585/Dialogia.n28.6737] 


\title{
Portfólios reflexivos e o ensino de ciências: estratégia inovadora de ensino
}

\author{
Reflexive portfolios and science education: \\ innovative teaching strategy
}

\author{
Alessandra Mocellim Gerevini \\ Graduanda do curso de Nutrição da Universidade do Vale \\ do Taquari - UNIVATES, Lajeado, RS - Brasil \\ amgerevini@universo.univates.br
}

Diógenes Gewehr

Mestre em Ensino. Doutorando do curso de Ensino da Universidade do Vale do Taquari - UNIVATES, Lajeado, RS - Brasil diogenes.gewehr@universo.univates.br

\author{
Andreia Aparecida Guimarães Strohschoen \\ Doutora em Ecologia. Professora dos Programas de Pós-graduação: Doutorado \\ e Mestrado em Ensino e Mestrado Profissional em Ensino de Ciências Exatas \\ da Universidade do Vale do Taquari - UNIVATES, Lajeado, RS - Brasil \\ aaguim@univates.br
}

\begin{abstract}
Resumo: Este estudo busca problematizar as implicações do uso de uma estratégia inovadora no ensino de ciências: portfólios reflexivos. Trata-se de um estudo descritivo e exploratório com abordagem qualitativa. Foi desenvolvido em uma escola pública do estado do Rio Grande do Sul/Brasil, tendo como sujeitos de investigação dois professores da disciplina de Ciências e seis estudantes do Ensino Fundamental, sétimo e oitavo anos. Os professores planejaram as atividades. Tanto eles, como os estudantes, utilizaram portfólios reflexivos individuais, que compõem os instrumentos de análise deste estudo. A pesquisa teve início em novembro de 2014 e término em outubro de 2015. Os portfólios produzidos foram analisados à luz da Análise Textual Discursiva. Os achados deste estudo permitem inferir a contribuição do uso de portfólios reflexivos para o aprendizado, estímulo ao pensamento crítico-reflexivo dos estudantes e desenvolvimento de sua autonomia.
\end{abstract}

Palavras-chave: Autonomia. Portfólio de Aprendizagem. Educação Básica.

\begin{abstract}
This study seeks to problematize the implications of the use of an innovative strategy in science education: reflexive portfolios. This is a descriptive and exploratory study with a qualitative approach. It was developed in a public school in the state of Rio Grande do Sul / Brazil, having as subjects of investigation two professors of the discipline of Sciences and six students of Elementary School, seventh and eighth years. The teachers planned the activities. They and the students used individual reflexive portfolios, which are the instruments of analysis of this study. The research began in November 2014 and ended in October 2015. The portfolios produced were analyzed in light of the Discursive Textual Analysis. The findings of this study allow us to infer the contribution of the use of reflexive portfolios for learning, stimulation of students' critical-reflexive thinking and their autonomy development.
\end{abstract}

Keywords: Autonomy. Learning Portfolio. Basic education. 


\section{Introdução}

As rápidas e crescentes transformações das sociedades contemporâneas têm colocado em debate, de modo muito expressivo, os aspectos relativos à necessidade de mudanças no ensino (COTTA; MENDONÇA, COSTA, 2011; COTTA et al., 2012; COTTA, COSTA, MENDONÇA, 2013). Muitas vezes a estrutura curricular tem restringido, em muitos aspectos, os processos de ensino e aprendizagem, levando apenas à reprodução do conhecimento. Neste caso, o educador assume o papel de transmissor de conteúdos de forma estática e autoritária, sem estímulo ao diálogo e à dúvida, cabendo ao educando, memorizar e repetir os conteúdos, sem a necessária crítica e reflexão imprescindíveis a uma aprendizagem que tenha significado para este (COTTA, MENDONÇA, COSTA, 2011; COTTA et al., 2012).

As preocupações que impulsionaram este estudo concentraram-se na percepção de que, diante da multiplicidade de aprendizagens exigidas pelo contexto atual, existe o risco de uma dispersão que confunde e fragiliza o processo de ensino. É preciso que haja um redimensionamento das práticas docentes, exigindo uma reflexão por parte dos docentes e discentes quanto ao seu papel e também quanto aos objetivos didáticos (CERRI; TOMAZELLO, 2011).

Observa-se que um dos grandes desafios para o ensino está na perspectiva de se desenvolver a autonomia dos educandos, principalmente considerando o processo de autoavaliação. Torna-se importante romper com o método formal de ensino focado na simples memorização, familiarizando o estudante com o processo de pesquisa, salientando o prazer da descoberta, focando na formação de cidadãos capazes de responder às necessidades do mundo atual e não apenas meros repetidores pouco criativos. Para tanto, o professor deve promover a investigação, a experimentação e a discussão, em vez de realizar apenas um repasse de conteúdos (SCHIEL, 2005).

O ensino deve, assim, ser capaz de proporcionar uma visão do todo, considerando a interdependência e a transdisciplinaridade. Possibilitando a construção de redes de mudanças sociais, alcançando a expansão da consciência individual e coletiva. Neste sentido, o processo de ensino parte da realidade do estudante, buscando a construção de estratégias que permitam a realização de mudanças, conforme o arco da problematização, proposto por Charles Maguerez (BORDENAVE; PEREIRA, 2011). Com isto, tem crescido a busca por métodos inovadores de ensino, que admitam uma prática pedagógica ética, crítica, 
reflexiva e transformadora, ultrapassando os limites de um treinamento técnico. É importante que o professor, neste sentido, propicie situações, tanto coletivas quanto individuais, para observações, questionamentos, formulação de hipóteses, experimentação, análise e registro, indagações, gerando um processo de intensa troca de experiências (PAVÃO, 2011). Desta forma, alcançando a formação de um ser humano como um ser histórico, inscrito na dialética da ação-reflexão-ação. As metodologias consideradas ativas possibilitam esta formação desafiadora necessária para nossos ambientes escolares (BORDENAVE; PEREIRA, 2011).

Neste contexto foi implementado o presente estudo que busca problematizar o uso de portfólios reflexivos no desenvolvimento da autonomia dos estudantes, tornando-os mais independentes e protagonistas em suas ações.

\section{Estratégias de aprendizagem ativa}

A utilização de estratégias de ensino que instiguem os estudantes a serem ativos é um desafio para os educadores. Tem se buscado uma práxis criadora, na qual seja possível, a formação de sujeitos crítico-reflexivos, corresponsáveis pela construção de seu próprio processo de aprendizagem ao longo da vida. Sua utilização implica não somente conhecer os modos de operacionalização, mas, fundamentalmente, os princípios pedagógicos que a sustentam, ou seja, os princípios da pedagogia crítica (PRADO et al., 2012). Esta mudança de foco do conteúdo para a aprendizagem, de processo para resultados, conduz à necessidade de implementar estratégias pedagógicas mais ativas e inovadoras do ponto de vista do estudante. É preciso implementar a utilização de novos instrumentos pedagógicos que permitam alcançar competências importantes para o exercício de ensinar (COTTA; COSTA; MENDONÇA, 2013).

Utilizar metodologias consideradas ativas e inovadoras significa apostar em uma educação que desenvolva processos críticos de ensino-aprendizagem, que desperte a criatividade e se baseie nela, que apresente as situações como problemas a resolver, ou seja, uma formação que se aproxime tanto quanto possível da vida real (BORDENAVE; PEREIRA, 2011; COTTA; MENDONÇA; COSTA, 2011).

Importa reconhecermos que há grande diferença entre "passar" informações e transformar a informação em conhecimento, fazendo com que o estudante realmente aprenda, auxiliando para que ele construa sua própria aprendizagem 
(ANTUNES, 2014). Neste ponto ressalta-se que o ensino de Ciências não se restringe a fatos, conceitos e informações, mas trata do entendimento e da prática dos processos existentes na produção do conhecimento científico. Sendo fundamental, desta forma, que o estudante possa efetivamente participar ativamente deste processo de aprendizagem (BIZZO; CHASSOT; ARANTES, 2013).

Podemos observar que estamos diante da sociedade da informação e que a escola não é necessariamente a primeira e imprescindível fonte de conhecimento para os estudantes. Estes precisam ter a capacidade de organizar e interpretar as informações, além de selecionar fontes adequadas. Para que estes adquiriram estas capacidades é importante que a escola desenvolva a criticidade dos estudantes, auxiliando para que tenham acesso às informações relevantes com assimilação crítica. Estes precisam aprender a conviver com a diversidade de fontes de informações, além de diferentes perspectivas sobre um mesmo assunto; construindo, assim, seu próprio julgamento, sendo aprendizes reflexivos e autônomos (POZO; CRESPO, 2009).

Como nos apresenta Alarcão (2011), o estudante não é um receptáculo pronto a receber conteúdos. É preciso que ele aprenda a gerir e a "relacionar informações para as transformar no seu conhecimento e no seu saber" (ALARCÃO, 2011, p. 17). Neste contexto, é importante que a escola instigue o estudante a utilizar e recriar o conhecimento, sabendo questionar, tendo pensamento próprio, desenvolvendo mecanismos de autoaprendizagem, assumindo responsabilidade de resolver problemas (ALARCÃO, 2011). Para tanto, é preciso utilizar estratégias de ensino e de aprendizagem que mobilizem o protagonismo dos estudantes, a reflexão constante e a criticidade.

\section{Portfólios reflexivos}

Dentre as estratégias pedagógicas consideradas ativas, do ponto de vista do estudante, há a construção do portfólio reflexivo, o qual é um método que proporciona um processo de ensino e aprendizagem ativo, cujo enfoque metodológico se baseia na comunicação dialógica entre os diferentes sujeitos. A intenção é que estes desenvolvam além de conhecimentos, atitudes e habilidades. É na ação, no desempenho perante as situações da prática que o estudante pode utilizar conhecimentos e habilidades ressignificados, por meio do conjunto de seus valores pessoais (LIMA, 2005). Ressalta-se o papel do portfólio reflexivo como indutor 
do trabalho em equipe, à potencialização do pensamento crítico e reflexivo (HERNANDÉZ, 2000; KLENOWSKI, 2007). Isto pois, o portfólio é uma construção pessoal do seu autor, sendo o momento de organização contextualizada de um determinado percurso (ALARCÃO, 2011).

No campo educacional - Ensino Fundamental, Médio, Superior e formação de professores - é possível desenvolver um portfólio, num processo de seleção e ordenação de amostras que reflitam a trajetória da aprendizagem de cada educando, mostrando assim os momentos mais significativos da aprendizagem de cada estudante. Além de colocar evidências sobre o seu percurso no portfólio e refletir sobre elas, os estudantes também podem contrastá-las com as finalidades iniciais de seu processo de aprendizagem e as intenções dos professores. Dessa forma, o portfólio apresenta-se como um facilitador da reconstrução e reelaboração do seu conhecimento (HERNANDÉZ, 2000).

O portfólio apoia-se em seis princípios básicos: construção, reflexão, criatividade, parceria, autoavaliação e autonomia. Construção, criatividade e autonomia, porque é o indivíduo que constrói, que o organiza e que o produz em diferentes linguagens; reflexão, porque ao colocar determinada atividade no portfólio há uma reflexão sobre o porquê desta seleção, da sua importância e da sua relação com o cotidiano do sujeito; autoavaliação, porque ao depositar atividades no portfólio o estudante analisa qual foi seu progresso; e parceria, pois nesta dinâmica não é somente o professor que produz, o estudante também é produtor e conta com o auxílio do docente (VILLAS BOAS, 2004; ALARCÃO, 2011).

Considera-se que o portfólio reflexivo constitui um modelo que procura atender à necessidade de aprofundar o conhecimento sobre a relação ensino e aprendizagem, assegurando aos estudantes e aos professores uma compreensão maior do que foi desenvolvido em aula. Desse modo, alcança índices mais elevados de qualidade, como meio de documentar e avaliar competências e habilidades dos estudantes. Nesse contexto, os professores tornam-se orientadores para atender o propósito de sua aplicação (OLIVEIRA; ELLIOT, 2012).

Assim, o portfólio reflexivo confere à pessoa o reconhecimento da sua capacidade para refletir de maneira autônoma e agir conforme seus pensamentos, conhecimentos e vontades. O desenvolvimento do pensamento reflexivo é considerado como um dos principais pontos positivos do uso do portfólio como estratégia pedagógica (ALVARENGA; ARAÚJO, 2006). Pode-se constatar que, através do portfólio, o educando é motivado a escrever sobre a sua construção de conhecimento. Na elaboração desta 
escrita o educando faz associações entre o conteúdo e sua caminhada, enxerga a função das atividades desenvolvidas e percebe a sua evolução, se autoavaliando. Em suma, o portfólio se traduz num instrumento autobiográfico na medida em que os educandos descobrem suas potencialidades ao analisar seu próprio trabalho e, é devido à proposta que recebe de escrever sobre a sua aprendizagem, que o educando é posto a refletir sobre esta (PRADO; SIMAS, 2012).

O processo de reflexão sobre a sua aprendizagem induz o estudante a realizar a autoavaliação, permitindo a oportunidade para sedimentar e ampliar sua aprendizagem (ALVARENGA; ARAÚJO, 2006; ALARCÃO, 2011). A avaliação, assim, tem sido um aspecto importante quando se analisa o portfólio, conforme relatado por Marin et al. (2010); Otrenti et al. (2011). Sendo ele considerado como um instrumento de avaliação processual e dialógica, contribuindo significativamente para a formação do estudante.

\section{Percurso metodológico}

O texto aqui apresentado é um recorte dos resultados de uma pesquisa denominada "Mestrado para formação de docentes: um lócus de (re)construção e aprendizagem", vinculada aos programas de Pós-Graduação: Mestrado em Ensino e Mestrado Profissional em Ensino de Ciências Exatas, de um Centro Universitário do interior do Estado do Rio Grande do Sul/Brasil.

Foi desenvolvido no período compreendido entre novembro/2014 a outubro/2015, em uma perspectiva de análise qualitativa, tendo como sujeitos de investigação dois professores de Ciências do Ensino Fundamental (P1 e P2) e seis estudantes, sendo três do sétimo (E1, E2, E3) e três do oitavo ano (E4, E5, E6) do Ensino Fundamental, de uma escola pública do interior do Estado do Rio Grande do Sul/Brasil. Estes estudantes foram selecionados por adesão à proposta, sendo incluídos como Bolsistas de Iniciação Científica Júnior (BICJr), para participarem diretamente no desenvolvimento da pesquisa. Os dois professores e os seis BICJr receberam auxílio financeiro, sendo a bolsa de orientação dos professores fomentada pela CAPES e dos BICJr concedida pela FAPERGS.

Os dois professores, juntamente com a equipe de pesquisadores, autores deste artigo, selecionaram e desenvolveram, nas duas turmas de estudantes, estratégias pedagógicas inovadoras norteadas por metodologias ativas de ensino e de apren- 
dizagem. Estas englobaram o desenvolvimento de competências e habilidades, formação intelectual, autonomia, interpretação e linguagem. Especificamente no presente texto, abordaremos o uso do portfólio reflexivo como estratégia pedagógica pelos sujeitos da pesquisa.

Os pesquisadores, professores, juntamente com os seis estudantes (BICJr) participaram de rodas de conversa para discutirem o desenvolvimento das atividades, sendo instigados a registrarem e refletirem sobre a caminhada escolar ao longo do ano em portfólios reflexivos, sendo estes os instrumentos de coleta de dados para análise nesta pesquisa. A análise destes ocorreu à luz da Análise Textual Discursiva proposta por Moraes e Galiazzi (2006).

\section{Resultados e discussão}

As atividades relacionadas com o presente estudo foram desenvolvidas durante os dois períodos semanais da disciplina de ciências nas duas turmas de estudantes. Nestes momentos os professores desenvolveram atividades englobando os conteúdos de Ciências dos sétimo e oitavo anos do Ensino Fundamental. Ao final de cada encontro os professores e os estudantes (BICJr) registravam suas impressões e percepções nos portfólios reflexivos individuais, salientando-se que nos portfólios não deveria haver somente a descrição das atividades realizadas em aula, mas que deveriam ser enriquecidas com pesquisas bibliográficas em livros, sites, revistas, etc., sendo imprescindível que se posicionassem criticamente em relação aos assuntos discutidos em aula. Objetivando enriquecer o material, combinou-se incrementar as ideias como tarefa de casa, principalmente considerando o curto tempo disponível para estes registros durante os períodos de aula.

Os portfólios dos alunos e dos professores participantes deste estudo foram analisados pela equipe de pesquisadores sendo que emergiram as seguintes categorias de análise:

\section{Categoria 1: Aspectos positivos do uso dos portfólios reflexivos}

Em relação à utilização do portfólio reflexivo, os estudantes relataram pontos positivos, dentre eles, destacam-se: o aprendizado diferenciado e inovador, 
o exercício da visão crítica-reflexiva, o trabalho em equipe, a criatividade, o estímulo à autonomia. 0 portfólio reflexivo permitiu que os estudantes, do seu ponto de vista, participassem ativamente dos processos de ensino e de aprendizagem e conquistassem com autonomia um crescimento para além da sala de aula. Isto é possível observar nas falas dos estudantes:

"A necessidade de escrever toda aula no portfólio fez com que nos envolvemos mais nas aulas. Vimos que os alunos e professor tanto ensinam quanto aprendem. Com o portfólio podemos nos expressar e dar nossas opiniões sobre tudo" (E2).

“... gostei da ideia de poder me expressar, colocar minhas ideias no papel, dizer o que eu penso e não ficar somente ouvindo. Notei que no portfólio eu podia colocar se concordava, não tinha medo de alguém não gostar ou não concordar" (E3).

“... foi legal discutir os assuntos com os colegas nos grupos. Havia gente que nunca falava nada e daí quando a gente se reunia nos grupos, falava muito. Era bem tri porque às vezes um não concordava com o outro e daí a professora vinha e dizia que não bastava concordar ou não com as ideias, que precisávamos argumentar e para isto tínhamos que ler mais, pesquisar e tudo isto ia no portfólio" (E6).

Da mesma forma que descrito por Alvarenga e Araújo (2006), os professores participantes deste estudo relataram que a produção dos portfólios como estratégia pedagógica demanda tempo e é um processo trabalhoso, tanto para o estudante como para o professor. No entanto, os benefícios de seu uso superam as limitações, pois neste momento de retomar as atividades desenvolvidas e analisá-las criticamente é possível tomar consciência de algumas ações que poderiam ter sido implementadas (MONTENEGRO; FERNANDEZ, 2015) na busca pela autonomia dos estudantes e não simplesmente o processo mecânico de "passar" conteúdos.

"A participação neste projeto de pesquisa, trouxe para a formação dos professores orientadores uma nova visão em relação aos métodos de ensino, mostrando que o método formal não cabe mais 
como forma única de trabalho nas escolas atuais. Isto ocorreu principalmente no momento da escrita dos nossos portfólios" (P2). "Com esta estratégia vi que há outras possibilidades de trabalhar os conteúdos em sala de aula. Não fiquei tão presa ao livro didático" (P1).

Observa-se na fala dos professores participantes deste estudo, que o portfólio reflexivo mostra-se como uma estratégia inovadora com potencialidade para auxiliar nos processos de ensino e de aprendizagem em sala de aula, afastando-se da monotonia do uso restrito do livro didático ou da aula estritamente expositiva.

\section{Categoria 2: Desafios do uso de portfólios reflexivos}

Muitos estudantes apresentaram resistência inicial em relação ao portfólio reflexivo, por exigir leituras, crítica, reflexão, busca ativa, discussões, retirando-os de sua zona de conforto - papel passivo de memorizar e repetir o que o professor ensina mecanicamente. Isto pode ser observado na fala dos estudantes:

\footnotetext{
"Tínhamos que tirar muito mais tempo para estudar e escrever no portfólio do que normalmente, e isso acabava ocupando as horas de estudos para outras matérias de aula" (E5).

“... era bem cansativo. No início nem sabia o que escrever, ficava meio perdida, achei que seria muito chato, não estava acostumada com esta ideia de ficar escrevendo e não copiando" (E3).
}

Nos portfólios reflexivos dos dois professores participantes da pesquisa, foi possivel perceber que as dificuldades iniciais relatadas relacionavam-se ao fato de os estudantes estarem habituados a estratégias pedagógicas que pouco os envolviam efetivamente de um modo mais ativo. Assim, os estudantes sentiam dificuldade em saber sobre o que deveriam escrever, não estavam habituados a refletirem sobre os momentos de sala de aula. Os professores participantes da pesquisa evidenciaram a expectativa da utilização do portfólio como estratégia 
de ensino para mobilizar os estudantes à responsabilidade pessoal sobre o seu processo de aprendizagem, semelhante ao descrito por Otrenti et al. (2011).

Como é normal na atividade docente, nem todas as propostas tiveram aceitação positiva por parte de todos os estudantes: "o que me aflige é a falta de interesse dos alunos" (P2). Assim como a condução das próprias atividades algumas vezes não atingiram o êxito esperado:

"Fico bastante angustiada, pois vejo que precisam ter tempo em aula para se reunir e para poder sentar e escrever, mas nem sempre dá tempo" (P2).

Nos dois primeiros meses do estudo, os portfólios continham apenas duas linhas no máximo para cada aula. À medida que o tempo foi passando, os professores puderam observar tanto um incremento na quantidade, quanto na qualidade da escrita. Sendo que, ao final deste estudo, os estudantes conseguiam expressar além da descrição da aula, comentários sobre como poderiam ter sido desenvolvidas as atividades e quais impactos tiveram sobre a sua aprendizagem.

\section{Categoria 3: Potencialidades dos portfólios reflexivos}

Os professores participantes da pesquisa realçaram em suas falas a importância dos portfólios como instrumento de avaliação dos estudantes (ARAÚJO; ALVARENGA, 2006) e principalmente, de autoavaliação:

“...a a analisar os portfólios produzidos pelos alunos, vi que eles conseguiam enxergar que ainda não conheciam o suficiente sobre os temas trabalhados em aula e que precisavam pesquisar mais..." (P1).

Os portfólios têm se mostrado como produções que enfocam o sujeito reflexivo e construtor da sua experiência pedagógica, possibilitando a reflexão sobre os fatos vivenciados, com seus múltiplos significados (RIBEIRO et al., 2009). Deste mesmo modo, no presente estudo observou-se que a construção dos portfólios pelos estudantes possibilitou aos estudantes e professores uma profunda reflexão 
sobre os processos de ensino e de aprendizagem, como se pode observar nas falas das professoras:

... "O uso de estratégias pedagógicas que busquem colocar o foco no trabalho do aluno para o professor provoca uma mudança no seu papel, não tendo mais o comando da aula o tempo todo, mas, sim, intermediando a construção feita pelo próprio aluno. E isto é possível ver quando temos que escrever em nosso portfólio, revendo nosso papel em sala"... (P1).

“... eu também no início escrevia muito pouco, não estava acostumada a refletir sobre minha prática pedagógica, fazia no "automático". Com o tempo, eu tinha sempre mais coisas para anotar e comentar..." (P2).

Um aspecto relevante citado pelos estudantes em referência ao uso de estratégias pedagógicas que coloca o estudante como foco, refere-se ao fato de estas facilitarem o aprendizado, rompendo com a forma mecânica de decorar e reproduzir os conteúdos. Eles puderam observar que, além dos conteúdos, é preciso desenvolver questões importantes para a vida, como: autonomia, responsabilidade, trabalho em equipe e solidariedade, o que pode ser demonstrado nas seguintes falas:

"Gostei muito desta aula, acho que poderíamos fazer mais aulas como esta, onde todos trabalham em grupo. Não sabíamos que todos deveriam trabalhar juntos, antes dividíamos a tarefa em partes e cada um fazia a sua, às vezes alguns nem faziam. Agora vimos que é importante que todos 'peguem juntos' ” (E6).

"Sempre vi que nas aulas de ciências deveríamos decorar todos os nomes de bichos e plantas etc. que o professor passava, mas com o uso dos portfólios reflexivos, vi que além de saber os nomes, preciso saber qual a relação disto com a minha vida e onde eu vivo” (E2).

Observa-se, assim, que os estudantes puderam refletir sobre o que faziam, como faziam e até mesmo avaliar os processos, sendo que o mesmo não ocorria antes do uso do portfólio reflexivo, segundo relato dos professores participantes da 
pesquisa. Salienta-se, desta forma, o potencial de desenvolvimento da argumentação e reflexão dos alunos do uso destes portfólios, como descrito por Gewehr et al. (2016), quando descreve os potenciais das estratégias inovadoras de ensino, como foco em metodologias ativas de ensino e de aprendizagem.

Conforme relatos dos professores pesquisadores, foi visível o amadurecimento dos estudantes no decorrer do processo: "no começo foi difícil convencê-los da importância das atividades, mas isso foi sendo construído com o passar do tempo. A própria discussão com eles sobre as formas como cada um aprende [...] fazem eles mais participativos" (P2). Os estudantes também reconheceram seu amadurecimento:

"Me admirei do meu crescimento, percebi muita diferença sei que agora estou preparado para o futuro, não totalmente, mas se vier algo parecido me garanto mais, não irei ficar tão nervoso, com tanta ansiedade, etc. Pude identificar mais qualidades minhas em função desse projeto, mais melhorias, ver como eu estava em aula, meu comportamento com colegas, professores etc. [. . .] Jeitos melhores em pesquisar, estudar, como fazer um trabalho melhor, com mais qualidade e aprendizado. Aprendi que nem todo trabalho é como se pensa, fazer por fazer sem querer aprender, só para ter nota, mas sim fazer para ter um conhecimento novo" (E3).

"Gostei de fazer o portfólio, foi bom fazer a capa do meu jeito, organizar, colar as coisas como eu queria. Coloquei reportagens que eu achava legal e a professora disse que era ótimo que eu estava pesquisando em diferentes lugares e assuntos relacionados ao nosso dia a dia" (E2).

$\mathrm{Na}$ fala dos estudantes é possível observar que mesmo com o projeto tendo tido a duração de apenas um ano foi possível produzir marcas interessantes e que se continuarem a sendo estimuladas poderão ser produtivas.

\section{Considerações finais}

O uso de estratégias pedagógicas inovadoras, especificamente considerando o portfólio reflexivo em sala de aula, promove o rompimento das aulas tradicio- 
nais, nas quais os professores assumem a frente das atividades, para um novo momento, onde os estudantes passam a refletir de uma maneira mais autônoma e crítica, sendo este um grande desafio para professores e estudantes. Inicialmente, observou-se neste estudo que estes tiveram certa resistência à proposta, alguns entenderem que agora o professor não iria mais "dar aula", pois as estratégias pedagógicas ativas tiram o foco do professor como responsável direto do "fazer acontecer". Mas, aos poucos, os estudantes foram compreendendo que o professor passou a ser um incentivador, procurando instigar neles a autonomia, através de tarefas mais complexas, que foram além do copiar e resolver questões do livro didático.

Os achados deste estudo evidenciam a contribuição do uso de portfólios reflexivos para o aprendizado e estímulo ao pensamento crítico-reflexivo dos estudantes, propiciando a aquisição de um conhecimento mais dinâmico, em função da possibilidade de interação entre a teoria com a experiência prática e a busca ativa pelos estudantes.

\section{Agradecimentos}

A equipe de pesquisadores agradece à CAPES e FAPERGS pelo auxílio financeiro recebido.

\section{Referências}

ALARCÃO, I. Professores reflexivos em uma escola reflexiva. 8 ed. São Paulo: Cortez, 2011. ALVARENGA, G. M.; ARAÚJO, Z. R. Portfólio: conceitos básicos e indicações para utilização. Estudos em Avaliação Educacional. v. 17, n. 33, jan./abr. 2006, p. 137-148.

ANTUNES, C. Professores e professauros: reflexões sobre a aula e práticas pedagógicas diversas. 9. ed. Petrópolis. Vozes. 2014.

ARAÚJO, Z. R.; ALVARENGA, G. M. Portfólio: uma alternativa para o gerenciamento das situações de ensino e aprendizagem. Estudos em Avaliação Educacional, v. 17, n. 35, p. 187-210, set./dez. 2006.

BIZZO, N.; CHASSOT, A.; ARANTES, V. (Org). Ensino de Ciências: pontos e contrapontos. São Paulo: Summus. 2013. 
BORDENAVE, J. D.; PEREIRA, A. M. Estratégias de ensino-aprendizagem. 31. ed. Petrópolis, Vozes. 2011.

CERRI, Y. L. N. S.; TOMAZELLO, M. G. C. Crianças aprendem melhor ciências por meio da experimentação? In: PAVÃO, A. C.; FREITAS, D. de. (Org.) Quanta Ciência há no ensino de Ciências. São Carlos. EdUFSCar. 2011. 332 p.

COTTA, R. M. M.; MENDONÇA, E. T.; COSTA, G. D. Portfólios reflexivos: construindo competências para o trabalho no Sistema Único de Saúde. Revista Panamenha Salud Public, v. 30, v. 5, p. 415-421, 2011.

COTTA, R. M. M.; SILVA, L. S.; LOPES L. L.; GOMES, K. O.; COTTA, F. M.; LUGARINHO, R.; MITRE, S. M. Construção de portfólios coletivos em currículos tradicionais: uma proposta inovadora de ensino aprendizagem. Revista ciência \& saúde coletiva, v. 17, n. 3, p. 787-796, 2012.

COTTA, R. M. M; COSTA, G. D; MENDONÇA, E. T. Portfólio reflexivo: uma proposta de ensino e aprendizagem orientada por competências. Revista Ciência E Saúde Coletiva, v. 18, n. 6, p. $1847-1856,2013$.

GEWEHR, D.; STROHSCHOEN, A. A. G.; MARCHI, M. I., MARTINS, S. N. M.; SCHUCK, J. Metodologias ativas de ensino e de aprendizagem: uma abordagem de iniciação à pesquisa. Revista Ensino \& Pesquisa, v. 14 n. 1, p. 225-246, jan./jun.2016.

HERNÁNDEZ, F. Cultura visual, mudança educativa e projeto de trabalho. Porto Alegre: Artmed Editora, 2000.

KLENOWSKI, V. Desarrollo de portafolios para el aprendizaje y la evaluación. 3. ed. Madri: Narcea, 2007.

LIMA,V. V. Competência: distintas abordagens e implicações na formação de profissionais de saúde. Interface Comum Saúde Educ, v. 9, n. 17, p. 369-379, 2005.

MARIN, M. J. S.; MORENO, T. B.; MORAVCIK, M. Y.; HIGA, E. DE F. R.; DRUZIAN, S.; FRANCISCHETTI, I.; ILIAS, M. O Uso do Portfólio Reflexivo no Curso de Medicina: Percepção dos Estudantes. Revista Brasileira de Educação Médica. v. 34, n. 2, p. 191-198, 2010 .

MONTENEGRO, V. L. dos S.; FERNANDEZ, C. Processo reflexivo e desenvolvimento do conhecimento pedagógico do conteúdo numa intervenção formativa com professores de química. Revista Ensaio Pesquisa em Educação em Ciências. v. 17, n. 1, p. 251-275, 2015.

MORAES, R.; GALIAZZI, M. C. Análise textual discursiva: processo reconstrutivo de múltiplas faces. Ciência \& Educação, v. 12, n. 1, 2006.

OLIVEIRA, D. L. de; ELLIOT, L. G. O portfólio como instrumento de avaliação da aprendizagem em escola montessoriana. Revista Meta: Avaliação, v. 4, n. 10, p. 28-55, 2012.

OTRENTI, E.; JODAS, D. A.; SILVA, L. G. DA; AGUILERA, T. K. DA C.; VANNUCHI, M. T. O. Portfólio reflexivo como método de avaliação na residência de gerência de serviços de enfermagem. Semina: Ciências Biológicas e da Saúde, v. 32, n. 1, p. 41-46, jan./jun. 2011.

PAVÃO, A. C. Ensinar ciências fazendo ciência. In: PAVÃO, A.C.; FREITAS, D.de. (Org.) Quanta Ciência há no Ensino de Ciências. São Carlos. EdUFSCar. 2011. 332 p. 
POZO, J. I.; CRESPO, M. Á. G. A aprendizagem e o ensino de Ciências: do conhecimento cotidiano ao conhecimento científico. 5. ed. Porto Alegre: Artmed, 2009.

PRADO, G. do V. T; SIMAS, V. F. A escrita no portfólio estudantil: possibilidades de reinvenção de si. Anais... XVI ENDIPE - Encontro Nacional de Didática e Práticas de Ensino UNICAMP - Campinas, 2012.

PRADO, M. L. do; VELHO, M. B; ESPÍNDOLA, D. S; SOBRINHO, S. H; BACKES, V. M. S. Arco de Charles Maguerez: refletindo estratégias de metodologia ativa na formação de profissionais de saúde. Escola Anna Nery Revista de Enfermagem, Rio de Janeiro, v.16, n.1, p.172-177, 2012

RIBEIRO, P. R. C.; LONGARAY, D. A.; BARROS, S. da C. A produção de portfólios reflexivos como prática avaliativa na formação incial de professores de ciências e biologia. Anais... VII Enpec. Disponível em: <http://posgrad.fae.ufmg.br/posgrad/viienpec/pdfs/1358.pdf>. Acesso em: 20 maio 2016.

SCHIEL, D. (org.). Ensinar Ciências na escola. São Carlos: Ed. CDCC USP, 2005.

VILLAS BOAS, B. M. de F. Portfólio, avaliação e trabalho pedagógico. Campinas, SP:

Papirus, 2004. (Coleção Magistério: Formação e Trabalho Pedagógico).

recebido em 16 jan. 2017 / aprovado em 31 jan. 2018

Para referenciar este texto:

GEREVINI, A. M.; GEWEHR, D.; STROHSCHOEN, A. A. G. Portfólios reflexivos e o ensino de ciências: estratégia inovadora de ensino. Dialogia, São Paulo, n. 28, p. 133-147, jan./abr. 2018. [DOI: 10.5585/Dialogia.n28.7081] 


\title{
Outras relações entre arte $\mathrm{e}$ educação: uma atitude política
}

Other relations between art and education: a political attitude

Carmen Lúcia Capra

Doutora em Educação pela Universidade Federal do Rio Grande do Sul. Professora da Graduação em Artes Visuais - licenciatura na Universidade Estadual do Rio Grande do Sul - Montenegro -RS, Brasil. carmen-capra@uergs.edu.br

\author{
Daniel Bruno Momoli \\ Mestre em Educação pela Universidade Federal \\ do Rio Grande do Sul. Professor na \\ Universidade Alto Vale do Rio do Peixe/ Faculdade SENAC - Caçador, SC. \\ danielmomoli@hotmail.com
}

Resumo: Este texto traz um conjunto de relações sobre arte e educação a partir de uma base teórica que compreende os campos da arte, da educação e da filosofia, provocando encontros interessados em produzir um modo de pensar a arte na educação desobrigada de certas noções de aprendizagem e ensino, ordens comprometidas com o alcance de resultados guiados por interesses exteriores. Aposta em pensar a escola como forma que torna presentes a arte e o mundo por meio dela, suspendendo os sentidos tradicionalmente atribuídos para o seu ensino. Nessa ideia de escola, uma atitude política toma a arte na escola como um meio de ruptura com as determinações incidentes sobre o conhecimento que vêm do mundo produtivo, capaz de fazer circular outros modos de pensar e habitar a escola.

Palavras-chave: Escola. Arte. Educação. Atitude política.

\begin{abstract}
This text brings a set of relations about art and education from a theoretical base that includes the fields of art, education and philosophy, provoking meetings interested in producing a way of thinking art in the education released from certain notions of learning and teaching, orders committed to the achievement of results guided by external interests. The text aims to think about the school as a form that makes art and the world present through it, suspending the senses traditionally attributed to its teaching. In this idea of school, a political attitude takes the art in the school as a mean of breaking with the determinations incident on the knowledge that come from the productive world, able to circulate other ways of thinking and to inhabit the school.
\end{abstract}

Keywords: School. Art. Education. Political attitude. 
O lugar da arte na educação escolar brasileira em nenhum momento foi estável. Manter os microespaços da arte na escola nos exigiu de algum modo uma negociação constante, em que a escrita se constituiu como uma arena política (PEREIRA, 2013). Sem que tenhamos encontrado um ponto derradeiro ou um juízo definitivo, estamos continuamente retornando ao trabalho de justificar a arte na educação. Se o encontro entre estes dois campos se faz necessário é porque nele, ou a partir dele, alguma possibilidade se apresenta como uma clareira com viés "separado das urgências do mundo produtivo, onde a sociedade pode se relacionar consigo mesma, sem as urgências nem as demandas da vida cotidiana" (LÓPEZ; MASSCHELEIN; SIMONS, 2017, p. 186).

O interesse por esses temas surge de nossa condição dentro desse campo: somos professores de arte que atuam em cursos de Licenciatura em Artes Visuais. As problematizações que aqui apresentamos foram sendo constituídas a partir de uma prática coletiva de leitura livre de textos ${ }^{1}$ que perpassam nossos trabalhos de pesquisa no campo da formação de docente em arte e também as atividades que realizamos em um grupo de estudo e pesquisa em arte e docência ${ }^{2}$. Esse texto é uma tentativa de provocar um encontro entre os campos da arte, da educação e da filosofia para produzir modos de pensar a arte e a educação a partir de uma relação desobrigada das promessas de melhoria individual e social, assim como desligada de certas noções de aprendizagem, ensino e escola. O que tem nos mobilizado é a possibilidade de encontrar um respiro que permita pensar diferentemente da maneira como pensamos as relações entre esses campos de saber, a fim de constituir novos argumentos para o que há tanto tempo proclamamos.

O texto está dividido em três partes. Na primeira, apresentamos a problematização que nos mobilizou novamente a pensar as relações entre arte e educação. Na segunda parte, colocamos sob suspeição algumas promessas atribuídas à arte para o campo da educação e, por fim, tentamos esboçar um horizonte que permita entrever outras relações entre educação e arte, mobilizados pela filosofia. Deste modo, intentamos contribuir para a ampliação dos limites das interrogações e das proposições que têm sido feitas para a confluência entre educação e arte.

\section{Uma interminável tarefa: a sempre necessária justificativa da arte na educação}

É ao lado de autores como Pereira (2010, p. 66) que escolhemos estar "atrás das sempre colocadas questões e preocuparmo-nos não tanto com as respostas, 
mas com o modo como lidamos ou como temos lidado com as perguntas, com os efeitos que as perguntas produzem em nós". No interminável trabalho - que em muito nos interessa - de justificar mais uma vez a arte na educação, colocamos sob suspeição alguns argumentos produzidos ao longo de três décadas, de 1987 a 2017, isto é, do ano em que ocorreu a criação da Federação de Arte Educadores do Brasil - FAEB 3 ao ano de amargo retrocesso que reduziu os poucos espaços conquistados para a arte na educação.

No Brasil, o interesse pela aproximação entre educação e arte intensificouse nos anos 1980. No contexto de redemocratização do país, a promulgação da Constituição Federal de 1988 apontava para a construção de um sistema educacional capaz de assegurar a formação básica comum e o respeito aos valores artísticos e culturais no contexto regional e nacional. A carta cidadã do novo regime republicano do Brasil permitiu que fosse feita a ampla discussão da Lei de Diretrizes e Bases da Educação Nacional. Assinada em dezembro de 1996, a Lei 9.394 apresentava no segundo parágrafo do Art.26 a obrigatoriedade do ensino da arte nos diversos níveis da educação básica.

Assegurar a obrigatoriedade do ensino da arte a partir de uma lei de tamanha importância para a educação brasileira requereu muitos esforços. A FAEB e muitas associações regionais empreenderam um movimento pujante com audiências públicas, "telegramaços" para Deputados e Senadores ${ }^{4}$, inúmeros abaixo-assinados e manifestos. Debateu-se com energia o uso de cada uma das expressões e dos termos utilizados na referida legislação para assegurar que as artes fossem integradas ao currículo da educação básica. No entanto, não foi por meio dessa Lei, nem mesmo pelos Parâmetros Curriculares Nacionais - PCN (1998) - que as aulas de arte foram garantidas na escola. Nem mesmo vigoraram as tão sonhadas vagas para os professores com essa formação específica. Essa foi uma batalha que nunca chegou ao fim.

Não podemos negar os avanços dos últimos anos a partir de ações como a formação docente e os projetos de incentivo a espaços com mais arte e mais cultura na escola ${ }^{5}$. Ao mesmo tempo, precisamos reconhecer os retrocessos, dos quais o pior deles mostrou-se em setembro de 2016 com a Medida Provisória 746 - posteriormente transformada na Lei 13.415 de 16 de fevereiro de 2017 -, que instituiu uma Reforma para o Ensino Médio desconsiderando as manifestações de entidades e associações das áreas de educação e arte. 
Diante dessa reconfiguração das políticas para a educação básica, não podemos esquecer que "a escola é, para uma enorme parcela da população, o único espaço disponível de iniciação da vida pública. E vida pública significa, salvo melhor juízo, uma existência mediada pelo legado cultural" (SAYÃO; AQUINO, 2004, p. 82). Fazer mudanças como as que estão em curso, ampliando a jornada escolar sem que estejam assegurados permanentemente os investimentos para tal, levará à oferta de um ensino mais precário e, consequentemente, poderá aumentar as taxas de evasão escolar, comprometendo o acesso de quase 2 milhões de jovens, com idade entre 15 e 17 anos, que estão fora da escola ou que trabalham e estudam. Além disso, a profissionalização como foco da formação, indiscriminadamente, vai afastar das juventudes uma base de conteúdos advinda das áreas da filosofia, da sociologia, da arte e da educação física ${ }^{6}$. Condenar uma geração a um processo de escolarização meramente voltado ao mundo do trabalho "sem a distribuição de certa experiência codificada" para a transmissão da cultura pela escola, obrigará os jovens - mulheres e homens, negras e negros, indígenas e LGBTS -, "a começar de novo toda vez" (DUSSEL, 2017, p. 96).

Nas manifestações pela defesa do ensino da arte, iniciadas logo após a divulgação das mudanças na educação básica, erigiu-se um campo de batalhas discursivas cujas lutas foram sendo travadas com expressões que traziam à cena enunciativa uma memória também discursiva. Palavras que demarcavam a superfície de sua emergência e expuseram "algumas feridas", na medida em que foram argumentos utilizados por mais de duas décadas, mas estavam ali em pleno funcionamento sem, no entanto, falar o suficiente para gerar um contramovimento. Foi em meio a essa luta discursiva que começamos a pensar ou a colocar em suspeição os argumentos que novamente estavam sendo utilizados para a arte estar na educação.

Nos argumentos elaborados com o uso de palavras como "cognição", "imaginação", "percepção" permanece em jogo uma certa promessa que insiste em justificar a arte na educação a partir de uma suposta contribuição para alguma coisa - a escrita, o raciocínio, a sofisticação do pensamento, a capacidade de leitura, a interpretação, a capacidade de resolução de problemas, a formação de valores humanos fundamentais, e a criação autoral sem submissão a modelos. Trata-se de um certo destino para o ensino de arte, útil a cada um individualmente e que contribui a todos na vida em sociedade. O murmúrio assim entoado segue invocando um determinado projeto educacional pensado para um modo 
de fazer escola que, otimamente, alia-se à domesticação da educação escolar, como "qualidade", "capacidade" e "habilidade". Uma forma-escola em que os limites da arte eram sinalizados por uma lista de conteúdos indicados em projetos pedagógicos e projetos de ensino que obedeciam a uma certa "linguagem das artes visuais" - cor, forma, equilíbrio, volume, ritmo - que funcionava como imperativo de um ensino formalista pautado na transmissão de um saber em direção às variadas formas de acesso à cultura.

Ao colocar tais argumentos em suspeição, estamos, de alguma maneira, liberando espaço para que outras relações possam vir a ser construídas entre a educação e arte. Para isso, uma exigência primeira seria atuar na desvinculação de um "reino das formas puras, das Verdades eternas, transcendendo o das realidades sensíveis, movediças, corruptíveis" (GROS, 2011, p. 315) para, ao contrário, criar "relações outras" em posição de ruptura com as formas habituais de pensar e fazer nos microespaços da arte na educação. Uma segunda tarefa consiste em desassociar certas promessas - da educação para a arte e da arte para a educação -, a fim de permitir que a escola seja um lugar onde uma atitude política possa vir a interromper o sentido habitual do mundo e, propriamente, os sentidos conhecidos para que a arte esteja nas escolas.

\section{Expectativas sobre a arte na educação escolar}

Entre as razões para a arte estar na educação escolar estão as que a consideram um logos, uma área de conhecimento específico, apropriado para desenvolver as capacidades cognitivas, perceptivas e sensíveis dos estudantes ${ }^{8}$, itens promotores de habilidades valorizadas para uma intervenção positiva na sociedade 9 . O ensino seria um veículo de aproximação entre a arte e o público, pois promoveria a argumentação e o juízo estéticos que tornam os indivíduos capazes de reconhecê-la e interpretá-la. Nesse raciocínio, há duas considerações importantes a destacar: primeiro, que o conhecimento e o exercício estético diminuiriam a distância entre as obras e os espectadores, uma distância conhecida e naturalizada. Em segundo lugar, conhecer arte e exercitar-se esteticamente também é compreender as proposições artísticas a partir de seu campo de origem, isto é, a arte dita como arte pelas instituições, pela história, pela crítica, pelas 
exposições. São dois princípios, tanto no sentido de serem começos, mas também instituições demarcadoras de verdades.

É preciso observar, então, se a experiência com a arte no seu ensino toma como parâmetro a experiência do espectador e de que é feita essa experiência. Quando falamos em ensinar e dar acesso à arte, muitas vezes visamos alcançar o lugar de quem não apenas olha, mas aprecia e dialoga com a obra de arte, motivos pelos quais o estudante aprende, avança, desenvolve-se. Existem, porém, condições específicas que dão a base que organiza e arte e a faz funcionar - o sistema da arte -, o que abrange o comentário sobre a obra, a exposição e as transações ao seu redor. O exercício estético do espectador faz parte desse sistema, pois é um dos componentes de elaboração de pensamento sobre as obras, assim como a crítica, por exemplo.

Antes, porém, está em ação uma base de pensamento e de percepção que é anterior ao sistema da arte. Há "um modo de ser sensível próprio aos produtos da arte" (RANCIÈRE, 2009, p. 31) que a identifica como tal, isto é, existe uma forma de reconhecimento que entende como arte todo objeto artístico que detém uma potência heterogênea e que está distanciado das conexões ordinárias com o mundo. Trata-se do regime estético ${ }^{10}$ que implementou procedimentos hoje incorporados, como a exposição de objetos especialmente potentes em lugares específicos, separados do curso da vida ordinária. Isto é: obras de arte detém uma potência estética e são expostas em museus, galerias ou bienais, lugares afastados tanto do ambiente de onde vieram as obras, quando do mundo comum, onde os espectadores podem relacionar-se com elas e exercitarem o juízo estético. Nisso, são várias as separações: artista e espectador, criação e apreciação, museu e mundo, obra e vida, espectador e obra, juízo estético e vida comum.

O regime estético da arte tomou forma no século XVIII, muito em razão das proposições de Immanuel Kant (1724 - 1804) e de Friedrich Schiller (1759 - 1805). Kant abordou a arte a partir da crítica do juízo estético, estabelecendo uma relação metafísica entre o fazer do artista e a lei do gosto. Schiller divulgou um modelo de experiência com a arte que necessita um estado específico e neutro do espectador, dado por uma educação estética capaz de formar os homens que viveriam numa "comunidade política livre" (RANCIÈRE, 2009, p. 39). ${ }^{11}$ Artista, obra, instituição e espectador são elementos de uma partilha sensível que delimita espaços, tempos e atitudes necessários a certa inteligibilidade da arte. Isso pode 
levar a educação em artes visuais na escola a guiar-se por uma experiência com a arte delimitada pelo juízo estético.

Quando o juízo, a elaboração intelectual ou a apreensão sensível conduzem a forma da experiência com a arte na escola, mesmo que a imagem ou a obra de arte sejam contemporâneas, é da perspectiva de uma experiência demarcada que estamos atuando. Ainda que compartilhada com outros, é uma experiência sensível individual da qual buscam-se construir interpretações, leituras, significados, juízos que comuniquem algo sobre a imagem ou a obra, tomando-a como um princípio pleno, solene, estável. Agamben refere-se ao juízo estético como um "puro nada" (2012, p. 79), remetendo-se ao olhar esteticamente especializado sobre a obra e entende, ainda, que a abordagem estética sobre a obra de arte forma um espectro evanescente em torno da criação artística que é acessível apenas ao artista. A principal consequência disso é a separação da experiência com a arte em duas e a implementação de uma distância: criar e apreciar/conhecer/julgar.

A interação com a arte pela via estética na educação, tendo-a como uma das formas constituintes do ensino de arte na escola, não é uma relação com a arte que sempre foi válida, tampouco é a fundadora de uma mais completa ou adequada relação com a arte. Pensemos com Foucault sobre a assunção de relatos indispensáveis à função fundadora do sujeito e que lhe garantiriam que "tudo o que lhe escapou poderá ser devolvido". A promessa de que o sujeito poderá "se apropriar, novamente, de todas essas coisas mantidas a distância pela diferença, restaurar seu domínio sobre elas e encontrar o que se pode chamar sua morada" (FOUCAULT, 2013, p. 15) podem estar constituindo as justificativas para o ensino de arte na escola. É preciso identificar quando o "discurso do contínuo" compõe as operações com a arte na escola a fim de mudar o pensamento e admitir as contradições e as descontinuidades constituintes do que a educação estavelmente entende como arte.

Não estamos querendo dizer que a apreciação estética da arte não seja importante, contudo esse modo de interação com a arte apenas pode ser sustentado pela distinção entre criação e apreciação (artista e espectador), mediada pela arte como objeto artístico. Propomos avaliar se estaríamos introduzindo elementos e estruturas como forma de acesso a um

belo fruto [...] que um destino benévolo nos colocou sob os olhos, sem, no entanto, nos restituir, junto com ele nem o ramo 
que o sustentou, nem a terra da qual se nutriu, nem o alternar-se das estações que maturou a sua polpa. Aquilo que foi negado é resumido no juízo com seu único conteúdo real, e aquilo que foi afirmado é recoberto por essa sombra: e a nossa avaliação da arte começa necessariamente com o esquecimento da arte (AGAMBEN, 2012, p. 79).

Em lugar de acessar toda e qualquer experiência artística, certas conformações podem estar distanciando a arte da educação escolar apesar de desejarem o oposto disso. Pensemos em aulas de história da arte, em visitas a exposições e como as imagens de obras são oferecidas como "inspiração" para a criação de trabalhos poéticos. Propomos pensar não somente no que a arte diz que pode para a educação e nem no que a educação diz que a arte pode para a escola, mas considerar a potência da arte e da educação, juntas. Em lugar de apontar uma "potência para", ousamos falar em potência, evitando predestinar de antemão a arte, a educação e os seus encontros. Pensamos na possibilidade do uso livre da arte na escola (CAPRA, 2017), uma atitude política para que a arte na educação não responda exclusivamente ao campo artístico ou a demandas de governo. Isso requer a adoção de uma suspensão do conhecimento instituído que, sem negá-lo ou destruí-lo, busca des-familiarizar, des-socializar, des-apropriar, desprivatizar o que é propriedade de outros, suspendendo a economia, as razões $e$ os objetivos (MASSCHELEIN; SIMONS, 2014) que definem, neste caso, a arte na educação básica.

\section{Um Horizonte para as relações outras entre arte e educação}

À guisa das considerações finais é preciso pensar não apenas escola, mas escolas em suas diferenças: centro e periferia, metrópole e interior, Europa e América Latina. Embora nossas problematizações tenham sido disparadas pelo momento que atravessamos no Brasil e em relação à reconfiguração das políticas para a educação básica, é preciso ampliar o horizonte em que nos colocamos e interrogar o que se passa, hoje. Talvez isso leve à exposição de fragilidades do nosso campo, mas possibilita encontrar pontos de tensionamento, inflexões necessárias que antes pareciam difíceis de serem encontradas. A partir de uma polifonia 
formada por autores advindos de campos distintos e cujas sonoridades ressoam sobre o campo da arte e da educação, nosso interesse é compor um espaço outro, um entre-lugar onde seja possível pensar, mais uma vez, em encontros entre a educação e arte.

Pensamos a escola com o intuito de alargar os limites onde nos colocamos, talvez margeados sempre pelas mesmas questões. Escola não é apenas aquela conhecida instituição, mas uma forma-escola que faz "o duplo movimento de trazer alguém para uma posição de ser capaz (e portanto transformar alguém em um aluno ou estudante), o que é ao mesmo tempo uma exposição a algo de fora (e assim um ato de apresentação e exposição do mundo" (MASSCHELEIN; SIMONS, 2017, p. 22).

Ao trabalhar na demarcação de novos encontros entre arte, educação e filosofia, a fim de estabelecer relações outras, buscamos de algum modo uma suspensão que provoque um giro no modo como temos pensado a escola e a arte, nela. Não mais a escola das formas puras, das grandes verdades, mas, a escola como iniciação na "vida pública e nos mistérios do mundo" (SAYÃO; AQUINO, 2004, p. 9) e como lugar de possibilidade, presença, indeterminação e igualdade (LÓPEZ; MASSCHELEIN; SIMONS, 2017). Nessas condições, a arte comporia uma estratégia disruptiva: quando estiver fora do lugar estabelecido politicamente, a arte pede e convoca novas autoridades e as questiona junto aos referentes sociais estabelecidos (DUSSEL, 2017).

\section{NOTAS}

1 É uma atividade que surgiu no segundo semestre de 2015 para uma leitura coletiva da aula inaugural de Michel Foucault no Collége de France, "A ordem do discurso". A leitura era realizada em um lugar qualquer, desde que permitisse a leitura em voz alta e os comentários da obra. O trabalho foi de tamanha relevância que se repetiu nos dois semestres de 2016 e de 2017 e passou a ser realizado em salas do Programa de Pós-graduação em Educação de uma Universidade Federal, a fim de melhorar as condições de leitura e conversação.

2 O Grupo de estudo e pesquisa do qual participamos surgiu em decorrência de discussões e investigações que tem tido como foco, principalmente, a relação entre arte, experiência estética e formação docente. O grupo de pesquisa foi criado em 2015.

3 A FAEB "surgiu, pois, da necessidade de representação das diversas associações estaduais e regional de arte/educadores em uma federação, que tivesse voz a nível nacional, em um momento em que nossas aspirações mais legítimas precisavam ser defendidas, pois estava para ser promulgada a nova Constituição que deveria orientar o nosso destino, como nação. 
A FAEB nasceu, portanto, com a finalidade de representar a luta pelo direito à arte e à cultura para todos os cidadãos brasileiros, e o fortalecimento e valorização do ensino da arte, em busca de uma educação comprometida com a identidade social e cultural brasileira" (RICHTER, 2008, p.325).

4 Para mais informações sobre as ações e registros da FAEB ver Richter (2008). Parte das histórias da defesa da arte na educação podem ser encontradas também na série de vídeos denominados de "Percursos daArte na Educação" disponível em: $<\underline{\text { https://www.youtube.com/ }}$ watch?v=2VTGUGaepDk>. Acesso em 28 jan. 2018.

5 Em referência a programas estratégicos de ação interministerial como o "Mais Educação" e "Mais Cultura nas Escolas". Mais informações em: < http://portal.mec.gov. br/programa-mais-educacao $>$ e $<$ http://www.cultura.gov.br/maisculturanasescolas $>$. Acesso em 28 jan. 2018.

6 Ver: nota produzida pelo Movimento Nacional em Defesa do Ensino Médio disponível em http://www.anped.org.br/news/manifesto-do-movimento-nacional-em-defesa-do-ensinomedio-sobre-medida-provisoria. Acesso em 28 jan. 2018. Ver também: Nota Pública da Associação Nacional de Pesquisa e Pós-Graduação em Educação - ANPEd, disponível em $<$ http://www.anped.org.br/news/nota-publica-da-anped-sobre-medida-provisoria-do-ensinomedio >. Acesso em 28 jan. 2018.

7 Utilizar a expressão "relações outras" não se constitui apenas como uma troca de lugar das palavras. É uma forma de escrita diretamente implicada com a espiral teórico-filosófica de sustentação de nosso pensamento a partir das proposições de Michel Foucault. Para mais informações consultar Foucault (2011).

8 O Parecer do Conselho Nacional de Educação/Câmara de Educação Superior No. 280/2007 fala da formação docente direcionada ao exercício da sensibilidade artística nas escolas. Disponível em < http://portal.mec.gov.br/cne/arquivos/pdf/2007/pces280_07.pdf>. Acesso em 29 jan. 2018.

9 Conforme a Base Nacional Comum Curricular, disponível em $<\underline{\text { http://basenacionalcomum. }}$ mec.gov.br/images/BNCC_publicacao.pdf>. Acesso em 29 jan. 2018.

10 Rancière (2009) identifica três regimes de inteligibilidade da arte: o ético, o representativo ou poiético e o estético.

11 Ver também as "Cartas sobre a educação estética da humanidade", escritas por Friedrich Schiller em 1793.

\section{Referências}

AGAMBEN, Giorgio. O Homem sem conteúdo. Tradução de Cláudio Oliveira. Belo Horizonte: Autêntica Editora, 2012.

BRASIL. Ministério da Educação. Parâmetros Curriculares Nacionais ( $5^{\mathrm{a}}$ a $8^{\mathrm{a}}$ Séries). Arte. Brasília/DF: MEC, 1998. 
CAPRA, Carmen Lúcia. Problematizações sobre políticas da arte na licenciatura em artes visuais: é preciso gostar da arte de outro jeito, a licenciatura é uma praça. Porto Alegre: Programa de Pós-graduação em Educação, 2017. (Tese) - Doutorado. 293 f. Faculdade de Educação da Universidade Federal do Rio Grande do Sul, Porto Alegre, 2017. No prelo.

DIDI-HUBERMAN, Georges. Diante da imagem: questão colocada ao fim de uma história da arte. Tradução de Paulo Neves. São Paulo: Editora 34, 2013.

DUSSEL, Inês. Sobre a precariedade da escola. In: LARROSA, Jorge (Org.). Elogio da escola. Autêntica: Belo Horizonte, 2017. p. 87-111.

FOUCAULT, Michel. A ordem do discurso: aula inaugural no Collége de France, pronunciada em 2 de dezembro de 1970. 20 ed. Loyola. São Paulo - SP, 2010.

Paulo, 2011.

A coragem da verdade: o governo de si e dos outros II.Martins Fontes. São

. A arqueologia do saber. Tradução de Luiz Felipe Baeta Neves. Rio de Janeiro:

Forense Universitária, 2013.

GROS, Frédéric. Situação do curso. In.: FOUCAULT, Michel. A coragem da verdade: o governo de si e dos outros II.Martins Fontes. São Paulo, 2011. p. 300-316.

LÓPEZ, Maximiliano Valério; MASSCHELEIN, Jan; SIMONS, Maarten. Skholé e igualdade. In: LARROSA, Jorge (Org.). Elogio da escola. Autêntica: Belo Horizonte, 2017. p.177-193

MASSCHELEIN, Jan; SIMONS, Maarten. A língua da escola: alienante ou emancipadora? In.: LARROSA, Jorge (Org.). Elogio da escola. Belo Horizonte: Autêntica, 2017. p.19-40.

não terminado). In: . ExperimentumScholae: o mundo mais uma vez... mas (ainda Horizonte: Autêntica, 2014. p.159-170. . A pedagogia, a democracia, a escola. Belo

PEREIRA, Marcos Vilella. Pesquisa em educação e arte: a consolidação de um campo interminável. Revista Iberoamericana de Educación, v. 52, p. 61-80, 2010.

. A escrita acadêmica: do excesso ao razoável. Revista Brasileira de Educação,

Rio de Janeiro, v. 18, n. 52, jan./mar. 2013.

RANCIÈRE, Jacques. A partilha do sensível: estética e política. São Paulo: EXO experimental; Editora 34, 2009.

RICHTER, Ivone. Histórico da FAEB: uma perspectiva pessoal. In: BARBOSA, Ana Mae (Org.). Ensino da arte, memória e história. São Paulo: Perspectiva, 2008, p. 323-334.

SAYÃO, Rosely; AQUINO, JulioGroppa. Em defesa da escola. Campinas: Papirus, 2004.

recebido em 30 jan. 2018 / aprovado em 2 mar. 2018

Para referenciar este texto:

CAPRA, C. L.; MOMOLI, D. B. Outras relações entre arte e educação: uma atitude política. Dialogia, São Paulo, n. 28, p. 149-159, jan./abr. 2018. [DOI: 10.5585/Dialogia.n28.8303] 


\section{RESENHAS / REVIEWS}




\title{
Lo femenino, entre centro y ausencia, de Miquel Bassols
}

\author{
Olivos: Grama Ediciones, 2017. 212 p.
}

\author{
Adriano Messias \\ Pós-doutorando em Tecnologias da Inteligência \\ e Design Digital (PUC-SP/ Fapesp), \\ pesquisador visitante na Universitat Autònoma de Barcelona, Université Paris 8 , \\ Université Paris 3, Universidade de Buenos Aires \\ adrianoescritor@yahoo.com.br
}

Diz-se que o mundo se feminiliza cada vez mais, ainda que a ciência, nascida sob a norme-mâle, insista em excluir o feminino de seu campo universalizante. Sabe-se muito bem dos disparates interpretativos da máxima que declara que todos os "homens" são iguais perante a lei. E a História comprova o quanto o sagrado e a bruxaria acabaram por acolher o que era rechaçado pela razão científica. Claro, a singularidade do feminino não se encaixará jamais na lógica do todo - lição básica da filosofia psicanalítica. O feminino é pas-tout, "não-todo". Mostra-se, assim, como uma pedra no caminho dos estudos da ciência e dos gêneros. A arte contemporânea, em grande parte, testemunha um airdutemps tempestuoso, entrecortado por movimentos reacionários e agressivos contra os corpos nus, contra a expressão da sexualidade, contra o desejo e contra a pulsão.

Para onde iremos?

Não se pode mais falar de pai e de mãe como há algumas décadas. Tampouco se deve entender a educação estando baseada no pedestal nada bastante das ideias cognitivistas. Há muito mais por ser considerado no abismo da singularidade de cada sujeito.

- O que acontece com o feminino no século XXI?

- "Procuremos a mulher" (alusão ao trecho do romance Os Moicanos de Paris, de Alexandre Dumas pai).

Visito, pois, em leitura, o psicanalista catalão Miquel Bassols, que tem por tradição nos oferecer livros com questões da ultimíssima ordem do dia, sem, entretanto, cair no limbo obnubiloso das ideias prontas, das palavras-chave, das vagues e dos modismos. O feminino está em pauta desde Freud - mas não somente - no campo das artes, do pensamento, das práticas sociais. Hoje, presencia-se o vaguear de alguns desesperados campos do saber em torno das questões de gênero 
e das conceituações complexas, a exemplo de "feminino" e "feminilidade". Somos uma época de grandes confusões epistemológicas e ontológicas.

Bassols, porém, toma como uma das fontes primordiais de seu livro o texto de Jacques Lacan - nada fácil, nada pronto, intraduzível muitas vezes até - intitulado em nosso idioma de Lituraterra. De chofre, Bassols afirma, bem no início, que o feminino não é um gênero; depois, salienta que não tem localização óbvia e que não pode ser pensado como um universal.

Então, qual seria o lugar do feminino na arte e na educação, por exemplo?

Se este lugar - de elipse - se faz, está entre o centro (simbolizado pelo falo) e a ausência (solitária) que se opera no gozo feminino, conforme enuncia o título da obra. A argúcia dos passeios teóricos de Miquel Bassols é embelezada por referências a Antígona, Medeia, Mallarmé, Agatha Christie, Borges, mas também pela aprendizagem linguística da criança autista e por alusões ao cinema. $\mathrm{O}$ autor conduz o leitor à constatação de que o feminino, a consciência e a linguagem são dimensões com as quais a ciência hodierna não dá conta de lidar.

E Bassols nos dá pistas eruditas. Ele sabe que não há respostas prontas, como bom pesquisador do humano. Freud anunciou a base ontofilogenética de nossa bissexualidade a partir de citações a respeito do mitológico Tirésias, sete anos transformado em mulher: não há no inconsciente qualquer representação possível da diferenciação sexual. Mais do que bissexuais, ressalta o catalão, estaríamos em uma posição $a$-sexuada (mas não "assexuada"), o que marcaria algo no mais além do falo. No caso específico do feminino, esse algo pode ser entendido como estando em um lugar que foge à noção espacial euclidiana: a "extimidade" conceito lacaniano que ainda se mostra muito desafiador e pertinente -, bem lá onde se encontra a "exterioridade interior".

O feminino seria, portanto, do êxtimo?

Para Bassols, o feminino (puro semblante) - que, nas gramáticas neolatinas curiosamente é regido por um artigo masculino - teria a ver com a Coisa (das Ding) neutra, e não com o gênero, sendo por isso, como ele afirmou, $a$-sexuado. 0 psicanalista alerta que existe um racismo sexista que provoca a violência contra (também) o gozo da mulher e o seu estar no mundo. Lê-se na página 72: "No hay, en realidad, pedagogía posible del goce del Otro". Por isso, conforme segue Bassols, é impossível a redução da subjetividade a qualquer sistema cibernético ou maquinal, como desejam o cognitivismo e as neurociências tradicionais. 
"Falar" e "gozar", conforme a psicanálise entende, pertencem ao humano. Há um gozo da/ na língua - não o fosse, o neologismo lacaniano lalangue não teria ocupado uma posição tão importante na análise de um sujeito e na interpretação das obras de arte.

A globalização do mundo acaba por implicar na pergunta "o que é uma mulher?": já não se encontram as mesmas identificações de antanho para com a mãe e com a maternidade. A infância e a loucura se somam aos objetos ferozmente segregados desde há muito, e, por isso mesmo, são submetidas tantas vezes a passagens ao ato.

Para o psicanalista, a violência de gênero traduz a impossibilidade de se compreender não só o gozo do Outro, como também a alteridade do gozo proporcionada pelo feminino em sua não universalidade. Nenhuma terapia cognitiva ou comportamental consegue organizar isso.

Disse pouco antes que Bassols nos conduz por pistas: uma das mais importantes reside no feminino em sua relação com o corpo e suas imagens, justo quando se mostra revelador do inconsciente para cada qual, independentemente de questões de gênero.

O inconsciente, bem pontuou Lacan, possuía um saber textual, organizado como uma linguagem. O inconsciente é sempre Outra coisa. Por isso,para ele, as mulheres só podem ser consideradas em relação ao feminino uma a uma. Também se deve a isso o fato de que não há simetria entre o feminino e o masculino, tampouco o primeiro se reduz à lógica fálica, como muitos quiseram. A metáfora maior de tudo o que Bassols propõe é a letra, capaz de expressar aquilo que não cessa de não se escrever na cadeia significante, cortando e recortando, sendo, assim, portanto, definitivamente feminina. É por isso que há um saber impossível e irrepresentável sobre o gozo.

Saber entrecortado. Além do falo. Em descontinuidade.

No claro-oscuro, o feminino (sempre singular). 


\title{
O culpado, de Georges Bataille
}

Belo Horizonte: Autêntica, 2017. 296 p.

\author{
Mônica de Ávila Todaro \\ Doutora em Educação pela UNICAMP. \\ Professora do Programa de Pós-Graduação em Educação \\ da Universidade Federal de São João del-Rei, Minas Gerais, MG - Brasil \\ mavilatodaro@ufsj.edu.br
}

Quem já leu Georges Bataille? O que esse escritor francês nos deixou como legado? Quais de suas obras estão presentes em nosso país? Seu pensamento alimenta quais teóricos?

Pensador da totalidade da experiência, escreveu colocando em evidência a unidade do espírito humano. De acordo com Roland Barthes (1984), "na verdade, Bataille escreveu textos, ou mesmo, talvez, sempre um só e mesmo texto". Segundo o próprio autor, "a desordem é a condição deste livro" (p. 50) que aqui se pretende, de maneira sucinta, resenhar.

Grande parte de sua obra não foi traduzida para o português, mas por aqui temos: "Suma ateológica", "Teoria da religião", "História do olho", "A parte maldita", "A experiência interior", "O erotismo", "A literatura e o mal", "Sobre Nietzsche: vontade de chance", entre outras, nas quais o diálogo está na base de seus escritos. Seu pensamento oferece sabores essenciais para aqueles que pretendem desfrutar do pensamento filosófico contemporâneo.

O livro Le coupable, publicado na França em 1944, ganha a tradução de Fernando Scheibe (Doutor em Teoria Literária pela UFSC, com tese sobre o conceito de soberania na obra de Georges Bataille) e nos é disponibilizado pela respeitada Autêntica editora, em 2017. O tradutor, nas páginas iniciais do livro, apresenta a obra e justifica duas escolhas que cabem aqui destacar: chance (traduzida como chance), uma noção ligada mais ao acaso do que à sorte; e néant (Nada), que aparece no seu uso mais substantivo: "o Nada".

Sob o título de "O culpado", Scheibe nos ensina que o livro foi o recorte do diário de Bataille, mas que perdeu um pouco esse caráter. O autor, numa entrevista, afirmou que "foi o primeiro livro que me deu uma espécie de satisfação 
[...]. É talvez o livro em que sou mais eu mesmo [...] porque o escrevi numa espécie de explosão bastante rápida e contínua”.

A obra em questão tem suas 291 páginas divididas em: A amizade; As desgraças do tempo presente; A chance; e A divindade do riso. Em seguida ao apêndice, é acrescentado um texto de 1947: A aleluia - catecismo de Dianus. Cada trecho é composto por frases curtas repletas de reflexões aprofundadas, num cenário de guerra.

Somos culpados, monsieur Bataille? De quê? De nossos desejos? De nosso inacabamento? De uma vida que nem sempre é o encantamento? "O homem é culpado: ele o é na medida em que se opõe à natureza" (p. 172), afirma o autor. A natureza não nos julga, mas o cristianismo funda-se na intolerância do homem para com ela.

Já que, para o grande pensador do século XX, "A potência maior é compensada por um sentimento de fragilidade exarcebada" (p. 36), então a potência da referida obra reside no fato de transitar entre a literatura e a filosofia, levando os leitores para fora de si mesmos, como se a "vida fluísse em rios lentos através da tinta do céu" (p. 39).

Além disso, ao longo do texto, Bataille nos alerta quanto "à selvagem impossibilidade que sou, que não pode evitar seus limites, e tampouco pode se manter neles" (p. 47). Isto é, ao falar de si, o autor gera reflexões e oferece recursos para pensarmos em nós.

Se "a autonomia do homem é física", então somos corpos livres, com vontade própria, para gerir a vida. "Vagidos de alegria, risos pueris, esgotamentos precoces" (p. 57), disso Bataille se diz feito. Ele pensa o corpo como veículo para compreensão do ser humano. Tal ideia me representa. Concordo plenamente com a mesma.

Enfim, "O culpado" merece ser lido tal qual um mergulho nos abismos daquilo que não sabemos. Sem facilidades. Acredito que, no momento de encontro com suas palavras que libertam, "se dissolverão em ti e se soltarão esses laços que obrigam o ser à solidez" (p. 206). As vias que Bataille mostra no livro são aquelas pelas quais não apenas ele passou, mas as que nos fazem compreender quem somos. É claro que esse é o meu olhar a respeito desta obra, mas o convite à leitura está feito. 
INSTRUÇÕES PARA OS AUTORES / INSTRUCTIONS FOR AUTHORS 


\section{Orientações para submissão de trabalhos à revista Dialogia}

Podem ser submetidos à análise da Comissão Editorial da Revista Dialogia, artigos e resenhas em português ou espanhol. As resenhas devem corresponder a obras recentes de, no máximo, um ano do ano de sua publicação.

Os trabalhos submetidos à Comissão Editorial serão avaliados em relação ao mérito científico, adequação às orientações da Associação Brasileira de Normas Técnicas (ABNT) às instruções editoriais contidas neste documento.

Os textos enviados deverão ser originais e inéditos no Brasil. Textos já veiculados em eventos científicos realizados fora do país não poderão ultrapassar um ano de sua divulgação e devem ter essa data explicitada. A Comissão Editorial não aceitará resenhas ou artigos submetidos simultaneamente a outras publicações, nacionais ou estrangeiras.

Os autores devem submeter o texto à revisão ortográfica e gramatical antes de apresentá-lo à Revista.

Todos os artigos submetidos a revista passam pela verificação do programa CopySpider (software detector de plágio).

Se a pesquisa que deu origem ao artigo envolver seres humanos, é necessário declarar que as abordagens e os instrumentos metodológicos utilizados obedeceram aos procedimentos éticos estabelecidos para a pesquisa científica em Ciências Humanas.

À Comissão Editorial reserva-se o direito de aceitar ou não os trabalhos a ela enviados e, eventualmente, sugerir modificações ao(s) autor(es), a fim de adequar os textos à publicação.

Os artigos devem conter, no máximo, 3 (três) autores. Todos os autores precisam ser identificados na plataforma de submissão online da Revista

$<$ http://www4.uninove.br/ojs/index.php/dialogia $>$.

Cada autor só poderá ter um manuscrito em tramitação, entre o início da submissão e a publicação final. Será observado um intervalo de dois anos entre a publicação de textos escritos pelo mesmo autor e o início de um novo processo de submissão. 
Para cada artigo exige-se que pelo menos um dos autores tenha o título de doutor.

O texto enviado não deve conter identificação do(s) autor(es). Para assegurar a integridade da avaliação por pares cega, para submissões à revista, deve-se tomar todos os cuidados possíveis para não revelar a identidade de autores e avaliadores entre os mesmos durante o processo.

Isto exige que autores, editores e avaliadores (passíveis de enviar documentos para o sistema, como parte do processo de avaliação) tomem algumas precauções com o texto e as propriedades do documento:

Os autores do documento devem excluir do texto seus nomes, substituindo com "Autor" e o ano em referências e notas de rodapé.

Em documentos do Microsoft Office, a identificação do autor deve ser removida das propriedades do documento (no menu Arquivo $>$ Propriedades), iniciando em Arquivo, no menu principal, e clicando na sequência: Arquivo > Salvar como... > Ferramentas (ou Opções no Mac) $>$ Opções de segurança... > Remover informações pessoais do arquivo ao salvar $>$ OK $>$ Salvar.

Os trabalhos enviados devem vir acompanhados, em arquivo separado, de formulário de autorização (conforme modelo disponível na página virtual do periódico) sobre a exclusividade de publicação do artigo pela revista Dialogia.

A instituição e/ou quaisquer dos organismos editoriais desta publicação não se responsabilizam pelas opiniões, ideias e conceitos emitidos nos textos, sendo esses de inteira responsabilidade de seu(s) autor(es).

Todos os trabalhos serão submetidos à leitura de, pelo menos, dois pareceristas, externos a instituição originária da revista, garantindo o sigilo e o anonimato tanto do(s) autor(es) quanto dos especialistas dos pareceres. Se a avaliação de ambos os pareceristas for positiva, compete aos editores decidir da sua publicação. No caso de um dos pareceres ser negativo, o artigo será encaminhado para outro avaliador.

O tempo médio entre a submissão do artigo e a publicação, mediado pelo processo de avaliação é de, aproximadamente, 6 meses.

As sínteses dos pareceres, em caso de aceite condicionado ou recusa, serão encaminhadas ao(s) respectivos autor(es).

Os trabalhos devem ser submetidos exclusivamente por meio da plataforma disponível no endereço eletrônico da Revista Dialogia. 


\section{Normas básicas de formatação}

Os textos devem ser elaborados conforme as instruções a seguir.

1) Digitados no Editor Word (.doc); fonte Times New Roman; tamanho 12; alinhamento à esquerda; sem recuo de parágrafo e espaçamento 1,5.

2) Os artigos devem ter entre 14 mil e 28 mil toques (considerados caracteres e espaços), e as resenhas, entre 3,5 mil e 7 mil toques (considerados caracteres e espaços).

3) Os artigos devem apresentar os seguintes quesitos:
a) Título;
b) Title
c) Resumo (entre cem e 150 palavras);

Os resumos deverão ter os principais indicadores do desenvolvimento do artigo. Obrigatoriamente, deverão conter o objeto de pesquisa, a questão de pesquisa, o modelo teórico utilizado como fundamentação, a abordagem metodológica, as categorias fundamentais e algumas das conclusões do estudo realizado, seja de caráter empírico ou meramente teórico.

d) Palavras-chave (máximo cinco) na língua de origem;

e) Abstract;

f) Key-words;

g) Ao final, obrigatoriamente, devem ser registradas as referências utilizadas no corpo do texto. (conforme padrão da publicação usar itálico, consultar ABNT para as normas).

4) As notas explicativas, que não se confundem com referências à fonte, devem vir ao final do texto (antes das referências), com numeração sequencial em algarismos arábicos.

5) As unidades de medidas devem seguir os padrões do Sistema Internacional de Unidades (SI), elaborado pelo Bureau Internacional de Pesos e Medidas 
(BIPM) [www.bipm.org]. Em casos excepcionais, a unidade adotada deve ser seguida da unidade expressa no SI, entre parênteses.

6) As palavras estrangeiras devem ser grafadas em itálico e os neologismos ou acepções incomuns, em fonte normal e entre "aspas".

7) Os trabalhos que exijam publicação de gráficos, quadros, tabelas ou quaisquer tipos de ilustração devem apresentar as respectivas legendas, incluindo a fonte completa. Os arquivos devem ser inseridos no texto e encaminhados separadamente e, sempre que possível, no formato original do programa de elaboração (por exemplo: CAD, CDR, EPS, JPG, TIF, XLS). As imagens devem ter alta definição (mínimo de 300 dots per inchs [DPIs]). Mapas ou micrografias devem ser representados com as respectivas marcas de escala.

\section{Normas para citações e referências}

As normas para citações nos textos a serem publicados na Revista Dialogia deverão seguir as determinações da Associação Brasileira de Normas Técnicas (ABNT). Para acesso ou aquisição das normas, consultar a página da mencionada instituição: <http://www.abnt.org.br/>.

Para acesso consultar as normas na página da Biblioteca <http://docs. uninove.br/arte/pdfs/manual-elaboracao-Trabahos-ABNT.pdf>

\section{Observação}

$\mathrm{Na}$ elaboração destas normas editoriais, foram consultados os seguintes documentos da ABNT: NBR 6023, NBR 6024, NBR 6027, NBR 6028, NBR 6034, NBR 10520, NBR 10522, NBR 10525, NBR 12256.

\section{Dialogia}

Fonte: ITC Garamond, Century Gothic 